Historic, Archive Document

Do not assume content reflects current scientific knowledge, policies, or practices. 



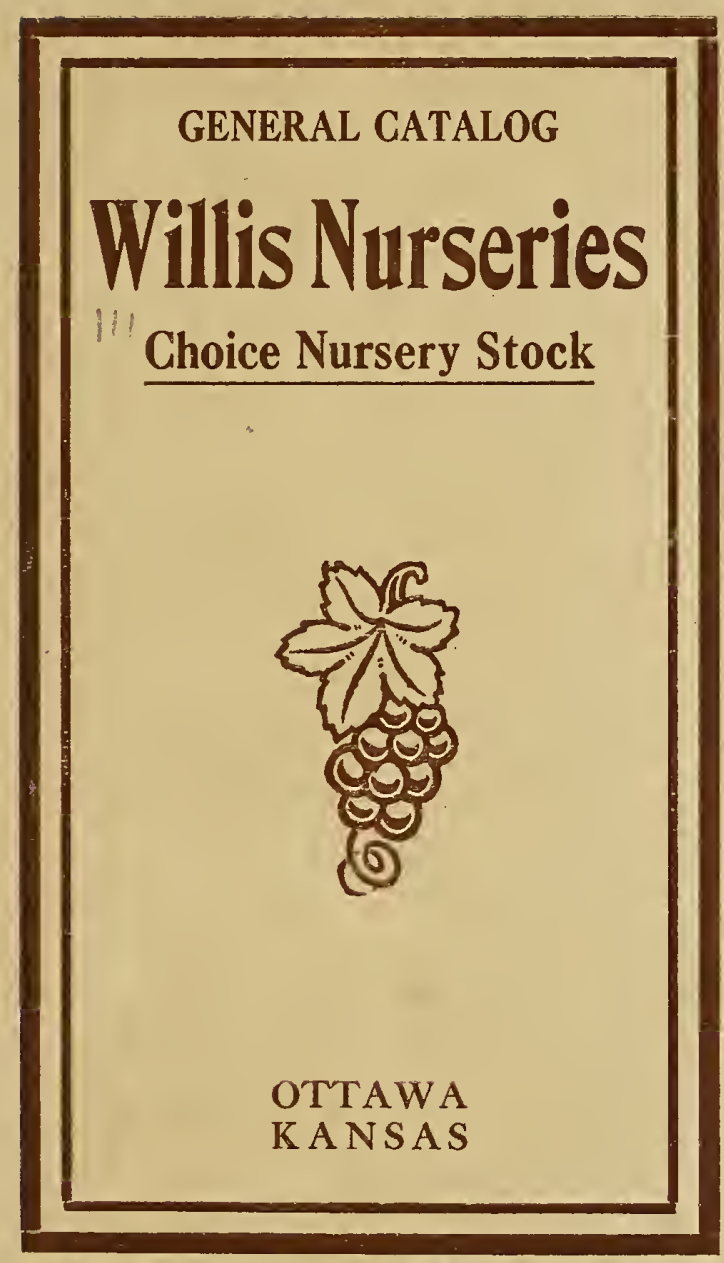

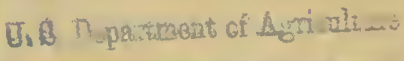





\section{Descriptive Catalogue}

\section{Willis Nurseries}

GROWERS OF THE

\section{Choicest Nursery Stock}

Office and Packing House East End of Fifth Street Long Distance Phone 25

A. WILLIS \& COMPANY PROPRIETORS

Established 1873

OTTAWA, KANS.

[On the Main Line Missouri Pacific and Santa Fe Railroads] 



\section{THE WILLIS NURSERIES}

\section{INTRODUCTION}

In presenting this new edition of our catalogue to our customers and the public, we wish first of all to express our thanks for the good patronage that has been extended to us. This patronage has enabled us to continue and to enlarge our business, and to increase the amount of goods we could offer our customers year by year.

The Willis Yurseries have never been so well able to meet the demands of a large trade as they are now, and we shall in the future, as in tne past, use our best efforts to make all orders sent us profitable to our customers. We seck a liberal share of the patronage of those needing goods in our line. These nurseries are located at the beautiful city of Ottawa, Kansas, on high prairie, and the stock is grown under the most favorable conditions to secure a well-developed system of roots and strong, shapely, well-grown plants.

We have a large force of experienced men, who give their attention to the production of the best stock, and no expense is spared in the cultivation, digging or handling of our stock, to get it to our customers in first-class condition. Our office and packing house are located within onehalf block of the paved streets of the city, and we are prepared to handle a large volume of business. The frost-proof storage house and packing plant is one of the best in the West. It is 100 by 200 feet and equipped with electric lights and city water. This enables us to handle our stock at all times where it is protected from the weather and where there is plenty of moisture. The main line of the Missouri Pacific and Santa Fe railroads, with their numerous branches and connections, furnish us good shipping facilities, and shipments are handled promptly for all parts of the country.

\section{VISITORS AND CORRESPONDENCE}

We are always glad to welcome visitors and to show them our stock and our packing plant, and to have them see how carefully our goods are handled. All correspondence, whether you wish to buy or not, will receive prompt and careful attention. We are always pleased to answer inquiries and make prices by letter, if you are interested in goous in our line.

\section{INSPECTION AND FUMIGATION}

Our nurseries are inspected each year by the State Entomologist, and all shipments are accompanied by a certificate of inspection. We are also prepared to fumigate where the state laws require fumigation. 


\section{ADVICE TO CORRESPONDENTS}

Orders should be sent in early, before the assortment is broken. When varieties are sold it is often impossible to replace them.

All orders should be written plainly on a separate sheet of paper, being especially careful about the name, post office and shipping point.

All orders will be carefully labeled, packed and delivered to the depot or express office in good condition, when our responsibilitiy ceases and customers must look to the forwarders for delay or damage in transit.

Remittances should be made by postal order, express money order, bank draft or registered letter.

Where particular varieties are ordered and particular sizes of trees and kinds of stock, etc., are desired, it should be stated whether and to what extent other varieties, ages, sizes, etc., may be substituted in case the order cannot be filled to the letter, as sometimes happens in all establishments.

Customers should give full shipping instructions, stating whether they wish goods sent by freight or express, and also the route. When these instructions are not given we forward according to our best judgment, but in no case will we assume responsibility after consignment to the purchaser.

Our customers will please notify us AT ONCE in case of any shortage or errors in filling their orders, that we may make proper amends. We are anxious to give all our customers the full worth of their money and to retain to the fullest extent their confidence.

The packing season with us usually begins from March 1st to March 15th and continues from April 15th to May 1st in the spring, and in the fall from about October 10 th to the 1st of December, and sometimes favorable weather continues till Christmas.

In this catalogue we make no pretense to giving the largest assortment, but we have tried to select a list of varieties that will, when planted and cultivated to fruitage, give good returns for the investment made.

\section{GUARANTEE OF GENUINENESS}

While we use every care to have all our trees, plants, etc., true to label and hold ourselves in readiness on proper proof, to replace all trees, plants etc., that may prove untrue to label, free of charge or refund the amount paid, it is mutually understood and agreed between the purchaser and ourselves that we shall in no case be liable for any sum greater than the amount originally received for said trees, plants, etc., that prove untrue.

\section{PLANT YOUNG TREES}

We cannot too strongly recommend to our customers the procuring of young trees, especially for orchard planting, instead of selecting the largest that can be had, to secure a more immediate effect. Young trees cost less at the nursery, also in freight, handling, and planting; they can be taken up with more perfect roots, and will become sooner established in a new location. They can also be more readily trained to any desired shape. The largest and most successful planters invariably select young and thrifty trees as the surest in the end to give thorough satisfaction.

For small grounds, or street planting, where it is necessary to make a show as soon as possible, large trees are often desirable, and when handled with care should not fail to do well, but with the general planter the average of loss will be much less and both time and money will be saved if young trees are selected to commence with.

We have been slow to recommend novelties, believing our customers would in the end be better satisfied with the good returns that can be realized from the planting and careful cultivation of the known reliable kinds. There are numerous candidates for favor offered to the planter every year, but the list of kinds our best horticulturists consider thoroughly reliable is not rapidly increasing. Would we then advise our customers to plant no new fruits? Hardly, and yet if you plant to raise fruit the most certain way is to plant well tested, successful kinds. if you plant new fruits, plant no more tnan you are willing to risk in an experiment. lf you have means 
and leisure to devote to them, there is nothing you can do as means of enjoyment within your reach that will afford more satisfaction than to experiment with horticultural novelties, and the effort to produce new fruits that will prove valuable yourself; and should you succeed in producing a new fruit that has real value, the public want it, and are willing to pay well for it.

\section{SOIL, ITS PREPARATION, EXPOSURE, ETC.}

Any soil that will grow good crops of corn and small grain will answer for fruit trees, etc. Eastern and northern exposures are usually considered the best, but perhaps more depends on the quality of the soil and its preparation, and after cultivation, than on the exposure. If the ground is naturally wet, spouty and cold, artificial draining is necessary before 'planting. Any ground sbould be well prepared by twice plowing, using the subsoil plow after the common one at the second plowing, and stirring the ground twenty inches or more deep, the deeper the better; this is not only for trees, but for small fruits as well. On good rich soil manuring will be unnecessary, but on poor soil, fertilizers, such as decomposed manure or compost, should be applied freely. Never grow small grain in the orchard, but always some crop that will require some cultivation, and the rows of trees should be kept cultivated at least until the month of August.

TRANSPLANTING-When the trees are received, open the bundles and heel in so that mellow earth will come in contact with all the roots. It may be necessary to apply water to moisten the soil; before planting, the ends of all bruised and broken roots must be cut sloping from the under side. If the soil is ploperly prepared the holes may not be dug much larger than to receive the roots in their original position. In planting in sod in yard or lawn the hole should be dug four to six feet in diameter and a little deeper than is necessary to set the tree, always using good mellow soil in filling in, pressing the ground well about the roots, and in such a manner as to leave them in their natural position as muchas possible. Water freely used in planting helps to settle the earth about the roots and a mulching of three or four inches thick and four to six feet in diameter should be applied as soon as the tree is planted, but the earth should be wel? Iressed about the tree before applying the mulching.

\section{DEPTH TO PLANT}

About the only correct guide that can be given in regard to the depth to be planteu is that when the ground is well pressed about the tree or plant it will be as deep or a little deeper than it stood in the nursery; and in this it is well to bear in mind that the roots of some trees, such as the Standard Pear, strike their roots deep, and require a deep hole, even to plant them as deep as they were in the nursery. Dwarf trees should be planted so that all the stock on which they are worked will be under the ground.

\section{PRUNING}

Cut back one-third to one-half of the last season's growth and one-year-old peach to almost a bare stock and headed back to the desired height for forming the top; the buds on the body of the tree will make a better growth and form a better top than if the side branches are left on. It is not advisable to do any of this pruning until just before the buds start in the spring. Remove the labels before the trees begin to grow.

\section{WINTERING TREES}

Procuring trees in the autumn for early spring planting is recommended when the purchaser is not prepared to plant in the fall or prefers spring setting or where the winters are too severe to set out young trees and plants in the fall; the greatest advantages in doing so are that when the roots have been cut or pruned, it will be found upon taking them up in the spring that a callus has been formed ready for the producing of new rootlets, and the trees being planted without much exposure as soon as the frost is out of the ground, will become thoroughly established the first season and will make twice the growth of late planted trees; and the labor of planting is then done before the rush of the spring work sets in. To insure success, select a dry spot of ground where water will not stand during winter, and where no grass or litter will invitə mice. Dig a trench fronı three to four feet wide according to the amount of trees to be heeled in and deep enough to admit one layer of roots and sloping enough to let the trees lay at 
an angle of about thirty degrees, throwing the earth on the back part of the trenches so as to malie a more perfect slope on wlich to lay down the trees. Put in one laver of trees, placing the roots as close together as can conveniently be done, cover with well pulverized soil well up on the bodies and as carefully worked in about the roots as if they were being planted; then add another layer of trees overlapping the first, and continue as at first until all are healed in, throwing the ground well up around the trench, ald where the winters are very severe it is advisable to cover the tree entirely up with eartl. Evergreen boughs or ccarse straw cr coln. fodder can be placed over the tops, but not thek enough to admit of a harbor for mice. The roots should be pruned before laying them down in the fall.

\section{TREATMENT OF TREES, E'TC.}

that have been frozen in the packages or received during frosty weather: Put them unopened in a cellar or some other cool, protected place, iree from frost, or cover them up heavily and entirely with earth until they are fully thawed out, when they can be unpacked and planted or nlaced in trenches until convenient to plant; treated in this way they will rarely be injured by freezing.

\section{A TABLE SHOWING THE NUMBER OF TREES OR PLANTS TO THE ACRE}

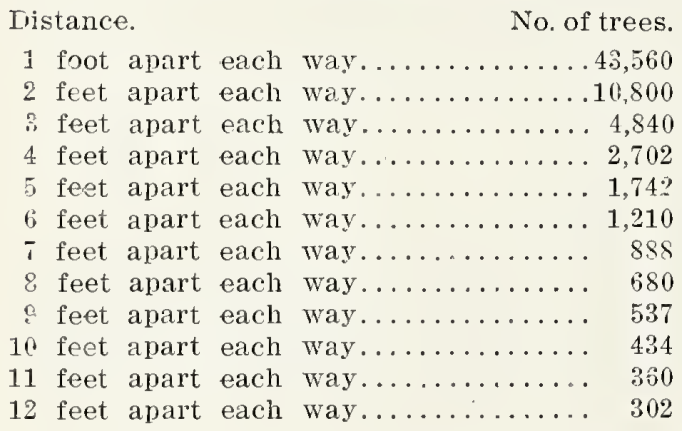

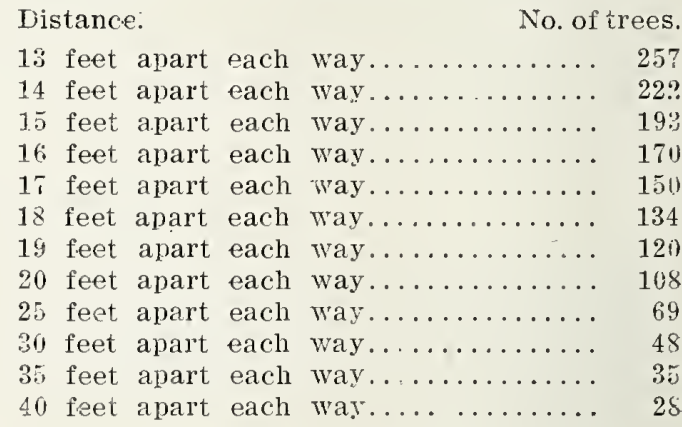

RULE-Multiply the distance in feet between the rows by the distance the plants are apart in the rows, and the product will be the number of square feet for each plant or hill, which, divided into the number of feet in an acre $(43,560)$, will give the number of plants or trees to trie acre.

\section{SUITABLE DISTANCES FOR PLANTING}

Apples, Standard ...................... to 40 feet Apples, Dwarf ........... 8 to 10 feet Pears, Standard ...........18 to 20 feet Pears, Dwarf .............. 10 feet Peaches .............................. 18 feet Nectarines and Apricots.......16 to 18 feet Cherries, Sweet ...........18 to 20 feet Cherries, Sour .............15 to 18 feet Flums ..................16 to 20 feet

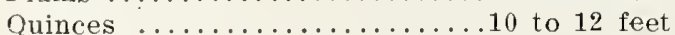

Grapes ............... \& to 10 feet Currants ............... 3 to 4 feet Gooseberries ...............3 to 4 feet Raspberries, Red ........... 3 to 4 feet Raspborries, Black ...........4 to 5 feet Blackberries .............5 to 7 feet Strawberries, rows ......... by $31 / 2$ feet Strawberries, in beds ........11/2 by $1 \frac{1 / 2}{\text { feet }}$ Asparagus, in beds .......... by $1 \frac{1}{2}$ feet Asparagus, in field .......... by 3 feet 


\section{FRUIT DEPARTMENT}

\section{APPLES}

The Apple stands at the head of the list in importance of all fruits, both for general cu! ture and for commercial purposes. Its seasons, unlike that of other fruits, extends neariy or quite through the year. By planting juãicious selections of Summer, Autumn and Winter sorts, a constant succession can be obtained of this indispensible fruit for family use.

As it takes from five to seven years for an apple orchard to come to bearing, some persons hesitate to plant, regarding the time too long to wait. If apples are planted at the rate of fiftr trees per acre, rows of peach trees can be planted between the apples, which, growing more cuickly than the apple trees, soon protect them from the wind, and thus are a great benefit to them. After eight or ten years of productiveness, as the space is needed for apples, the peach trees may be removed, leaving the orchard better for the protection and at the same time having yielded the planter a large return for his trouble.

The Apple will thrive on any good, well-drained and well-cultivated soil, and no farm crol' will produce and pay returns on the investment and care bestowed upon it as well as the apple orchard. The demand for apples in the market is steadily increasing and American apples are being sold the world over.

The varieties named here sre those best adepted to this locality and regaraed as most likely to produce the best results.

\section{SUMMER APPLES}

Carolina Red June-Tree moderate, upright grower, early and abundant bearer. Fruit small to medium, oblong; surface smooth; color dark red and white ground; flesh white, very tender, fine grained, juicy, acid. Quality good; use table and market. Season June and July.

Cooper's Early-Size medium, color pale yellow with faint blush on sunny side; flesh white, crisp, sprightly, mild acid, a good cooking variety; tree hardy, an early bearer and heavily productive.

Duchess of Oldenburg-A Russian apple of great value; tree moderate grower and hardy, fruit medium size; surface smooth, waxen yellow with stripes and splashes of red; flesh white, tender and juicy; sour and good for cooking. Season June ani July.

Early Harvest--The most popular summel apple on our list; tree healthy, vigorous grower and good benrer; fruit medium size, nearly round, somewhat flattened; surface smooth, clear waxy yellow, rarely blushed; flesh tender. juicy, acid to sub-acid, flavor good; quality best, use table and kitchen. Season July.

Red Astrachan-Another Russian appie that has proved to be very popular with planters; tree vigorous, upright grower; hardy and productive; fruit medium to large; surface smooth. marbled and striped on greenish yellow, flavor acid, use kitchen and market.

Summer Queen-Tree vigorous, large spreading, productive; fruit medium, round, surface yeilow, covered with mixed red and scarlet; flesh firm, yel- low; flavor acicl, spicy; quality very good; use kitchen. Season July and August.

Sweet June-Tree strong, upright grower, very productive; fruit small to medium, round, greenish-yellow; flesh white or greenishwhite, fine grained, tender; quality good; use table and kitchen. Season Jine and July.

Yellow Transparent-A Russian variety, new and promising in the North; tree hardy ant moderately vigorous, an early and goo? bearer; fruit medium, smooth, skin clear white at first, becoming pale yellow when fully mature, often with a clear blush cheek; flesh white, tender, juicy, sub-acid; quality good. Season early in August

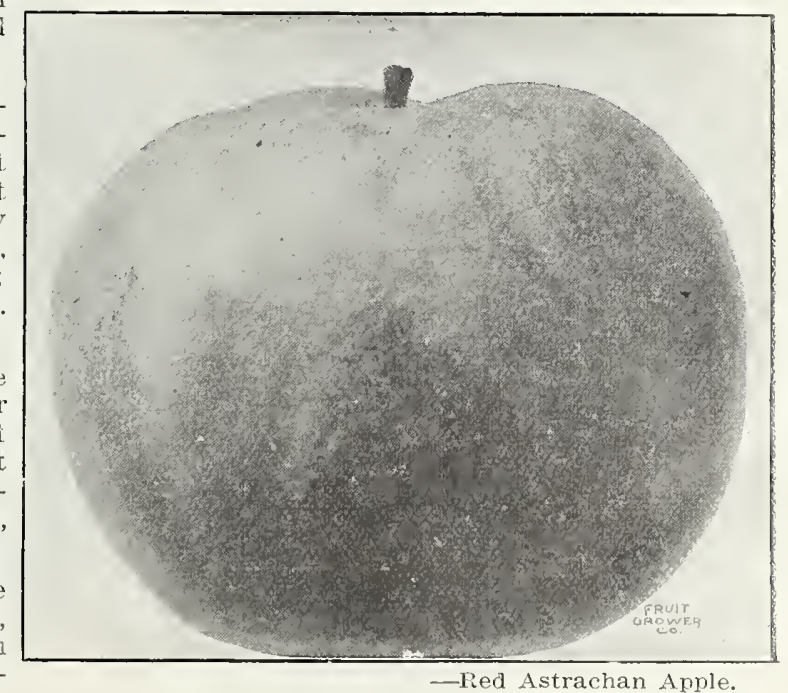




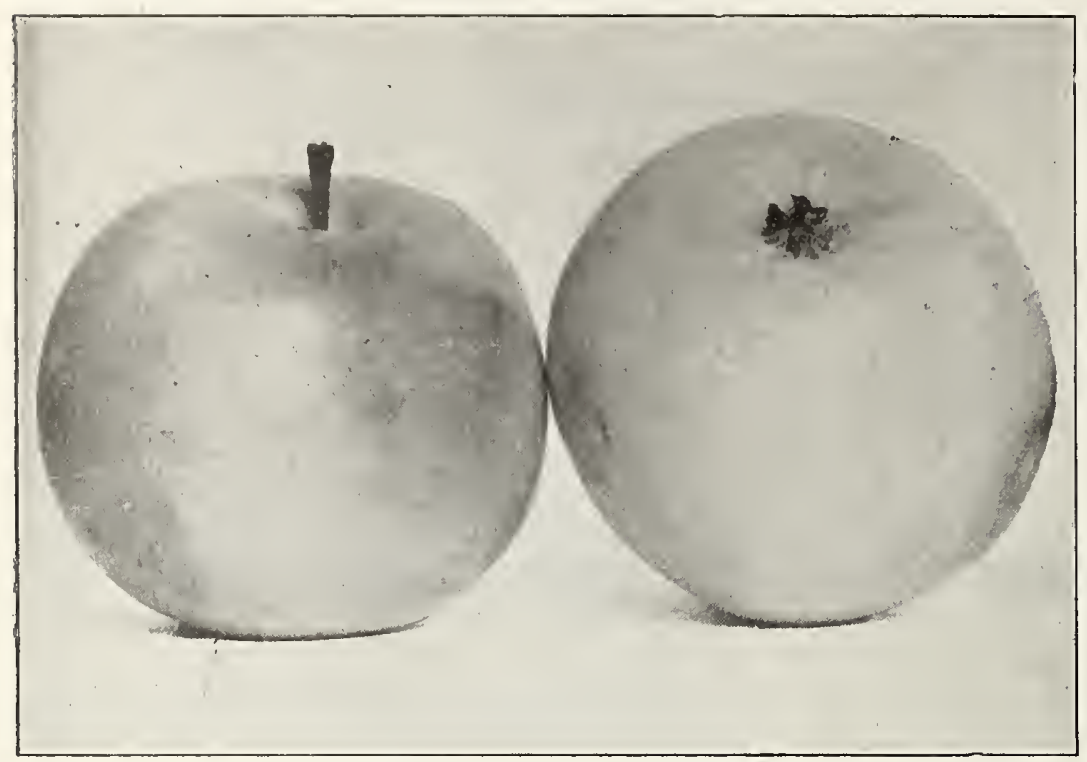

FALL APPLES

Autumn Strawberry - Tree lupright, thrifty grower; fruit medium, roundish, angular; surface smooth, waxen, yellow mixed and striped with scarlet; flesh yellow, tender, fine grained, very juicy; quality best, for dessert especially. Season August and September.

Bailey's Sweet-Fruit large, round, mottled anc striped deep red; flesh yellow and tender, with a mild, rich, sweet flavor; quality best., Season September.

Fall Pippin--Tree strong grower, not an early bearer, moderately productive when old; fruit large, globular; surface smooth, rich yellow, sometimes blushed; flesh yellow, very fine grained; flavor acid; quality best.

Fameuse (Snow Apple)-Tree hardy. vigorous and productive; a fine apple of medium size, round, surface pale yellow nearly covered with rec. made up of stripes and splashes; flesh snowy white, tender, fine grained, juicy: flavor mild, sub-acid, very good.

Lowell-Tree strong, vigorous grower and good bearer; fruit large to very large, round; surface smooth, waxen yellow, not blushed, becoming greasy when lept indoors; flesh yellow, fine grained, juicy; flavor sub-acid; quality very good. Season August and September.

Maiden's Blush-Rather large, oblate, smooth, regular, with a fine, evenly shaded red cheek or blush on a clear, pale yellow ground; flesh white, tender, sprightly, with a pleasant sub-acid flavor; bears

i Rarge crops. August and September.
Ram bo- Medium, yellowish, streak ed with dull red and somewhat dotted; mild, tender and good; productive and vigorous. Season September to November.

\section{WINTER APPLES}

Arkansas Black - A beautiful a p ple; fruit is large and smooth, roundish; rich dark red; yellow flesh, juicy and good; a late keeper

Ben Davis-Tree is thrifty, an upright grower of almost perfect $\mathrm{sh}$ a p e. Fruit large, round, sometimes variable in form, sur. face smooth, often -Yellow Transparent Apple. polished, bright yellow covered with red and splashed; flesh white, tender, juicy; flavor sub-acid, not rich, quality only good; use market and cooking. Season November to spring.

Baldwin-Tree strong, thrifty grower; fruit large. round or somewhat flattened, sometimes irregular; surface smooth, yellow in shade, when exposed red; flesh yellow, juicy, rich; quality good; use table and cooking. Season October to Deceniber.

Bayard-Tree upright, vigorous grower; abundant and constant bearer; fruit large, round;

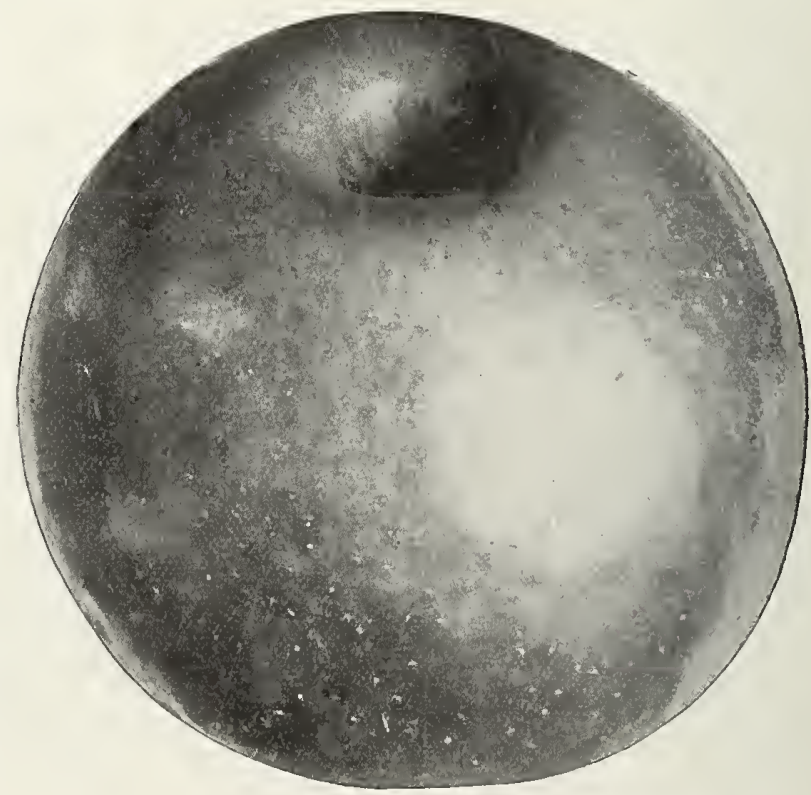

-Gano Apple. 


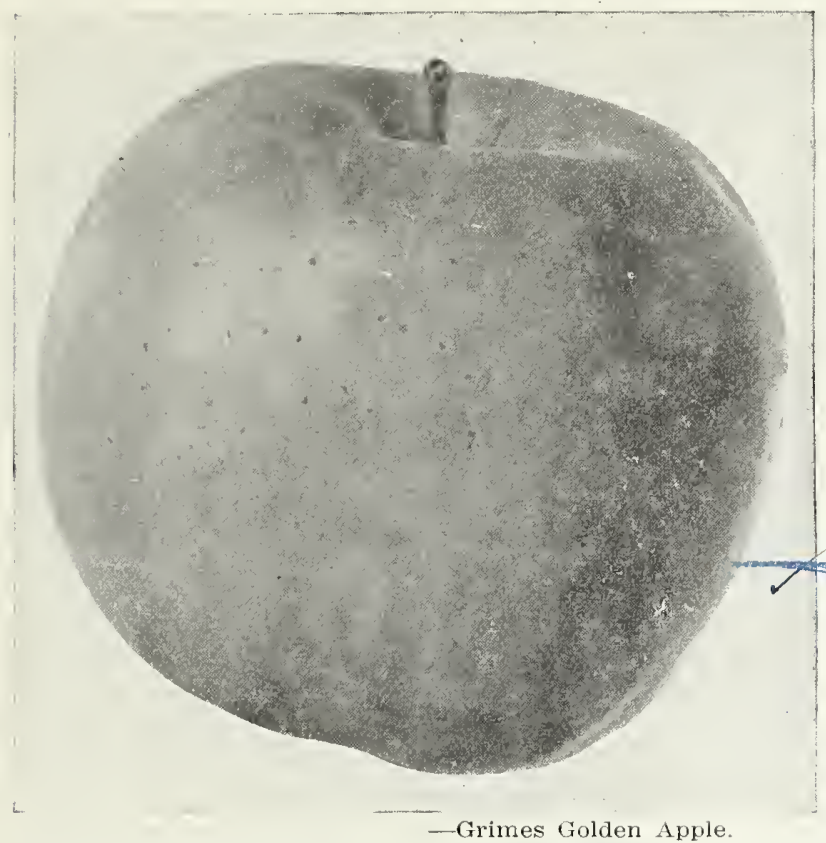

greenish vellow, delicate, tender, juicy, sub-acid. A late keeper.

Janet-Tree good grower, not so large as some; fruit medium, somewhat conical, regular; surface smooth, mixed and striped on yellow and green; flesh yellowish, crisp, fine grained, juicy; flavor sub-acid; quality good to very good. Seasou November to spring.

Jonathan-Tree rather slender growth and spreading habit; fruit medium, round or oblong, surface very smooth, deep, rich red; flesh whitish yellow, tender, very juicy; quality best. One of the most yrofitable market apples. Season October to November.

Mammoth Blacktwig - Originated in Tennessee. Tree a fine upright spreading grower, bear's large crops and holds its fruit well; the fruit is fully one-fourth larger than the Winesap, which it resembles very much in color, flavor and keeping qualities. November to April.

Mann-Tree strong and upright grower; fruit medium to large, roundish,

skin dark red with white dots; flesh white, fine grained, solid, crisp, juicy, with a refreshing vinous flavor. Season Otcober to May.

Clayton-Large, yellow, striped, flesh yellow; sub-acid; favorite cooking apple. Season January to May.

Gano-It very much resembles Ben Davis, both in tree and fruit, but is superior. Tree is a good grower, an early and abundant bearer; fruit is large, smooth, dark red; flesh yellow, fine gained, sub-acid; a good shipper and keeper.

Gilpin, Little Red Romanite-Tree very strong grower with spreading, open top. Fruit medium to small, round flattened at the ends; surface smooth, deep red; flesh greenish yellow, firm, juicy: flavor rich, little if any acid; quality is good; one of the longest keepers. Season February to May.

Grimes Golden--One of the most popular apples in cultivation. Tree strong, thrifty grower, spreading branches; fruit medium or above, cylindrical, regular, surface yellow, russeted; flesh yellow, firm, very ïine grained, iuicy: flavor sub-acid, rich; quality best.

Huntsman-Tree very upright, thrifty grower and good bearer; fruit large; color a rich yellow when fully ripe; sliape round, considerably flattened at the ends; flesh pale yellow and somewhat coarse, juicy and rich, acid, very good. Season November to March.

Ingram-A seedling of Rawles' Genet. Tree more upright, fruit medium size. roundish, inclined to conical, smooth, yellow ground, striped bright red; flesh oblate; skin decp yellow when fully ripe, often with a shade of brownish red; flesh yellowish, juicy, mild, pleasant, sub-acid.

Milam-Tree moderate grower, annually pro ductive and an early bearer; fruit medium, conical, regular; surface smooth, yellow covered with marbled red; flesh white, tender, juicy; flavor sub-acid and refreshing; quality good. Season October to December.

Minkler-Fruit medium, roundish, oblate, slightly conical, pale greenish yellow, striperl and splashed with two shades of red; flesh yellowish, compact, moderately juicy, mild,

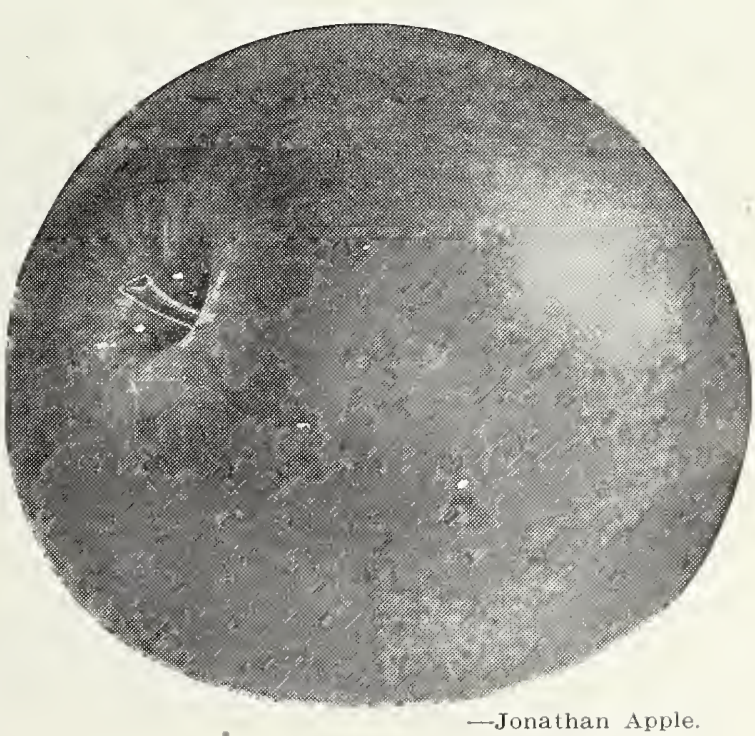




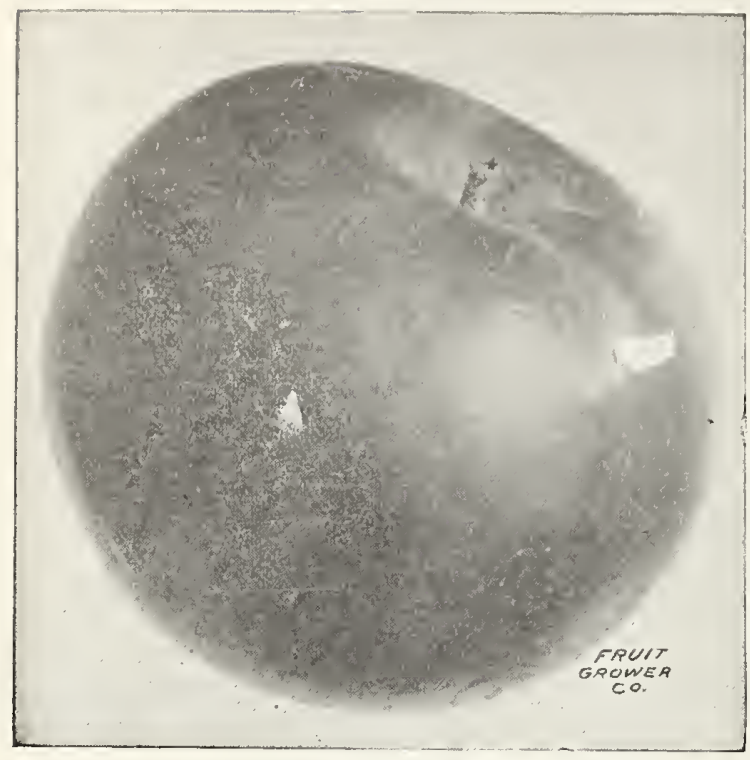

-Stayman Winesap Apple.

pleasant, sub-acid; tree irregular grower season January to April.

Missouri Pippin-Tree strong upright grower and great and early bearer, the branches frequently breaking down under the burden of fruit; fruit medium or above in size, rich. bright reil striped and splashed, over yellow ground; large, oblong, flattened at the ends; flesh yellow, flavor acid; quality good Season November till spring.

Northern Spy-Tree strong upright grower, does not bear young; a good bearer when old; fruit large, roundish, sometimes angular; surface smooth; yellow, mixed and splashed with crimson; flesh yellowish white, breaking, juicy; flavor acid, rich: quality best. Season September to Noventber. North and East is one of the best winter apples.

Rhode Island Greening Tree strong grower, croulked, spreading, productive. Fruit large, varying in shape from round to flat, surface somewhat rough and russeted; color dull green, becoming yellow at maturity; flesh very yellow, juicy with rich acid flavoi; quality very good. Season September to November.

Roman Stem-Tree moderate grower and productive. Fruit medinm, globular; surface smooth, yellow. sometimes blushed; flesh yellowish white, fine grained and juicy; flavor mild, sub-acid, rich; quality very good. Season October to December.

Rome Beauty-Tree thrifty upright grower. Fruit is large to rery large, roundish oblate, sometimes conical; surface smooth, pale yellow, striped and nixed with red; flavor sub-acid, not rich; quality good; desirable market fruit on account of its productiveness and fino appearance. Season November to January.

Smith's Cider-Tree strong grower and hardy; fruit medium, round, sometimes lop-sided; surface smooth, pale yellow, covered with mixed light red, splashed with carmine; flesh white, juicy; flavor acid, not rich. Gcod for cooking.

Stayman Winesap-Originated on the grounds of Dr. Stayman, Leavenworth, Kansas; tree hardy, vigorous, spreading, irregular, tough, wiry, droops like a weeping willow with loads of fruit, never breaking a limb; an early bearer and very productive; fruit medium size, round, approaching conic; skin smooth, greenish yellow, splashed and striped with red and purple, covered with a white bloom, dots small, gray, scattered; flesh yellow, firm, tender, juicy, rich, mild, sub-acid, aromatic, quality best. Season January to May.

Tallman Sweet-Tree hardy and strong grower; fruit medium, nearly round, somewhat flattened; surface smooth yellow; flavor sweet, rich; flesh yellow and firm. Season October to December.

Walbridge-Tree strong grower and productive, highly, prized farther north for its extreme hardiness; fruit medium size, color pale yellow shaded with red; flesh crisp, tender and juicy; quality good. Season December to spring.

Wealthy-Another tree highly valued for its extreme hardiness at the far North; tree

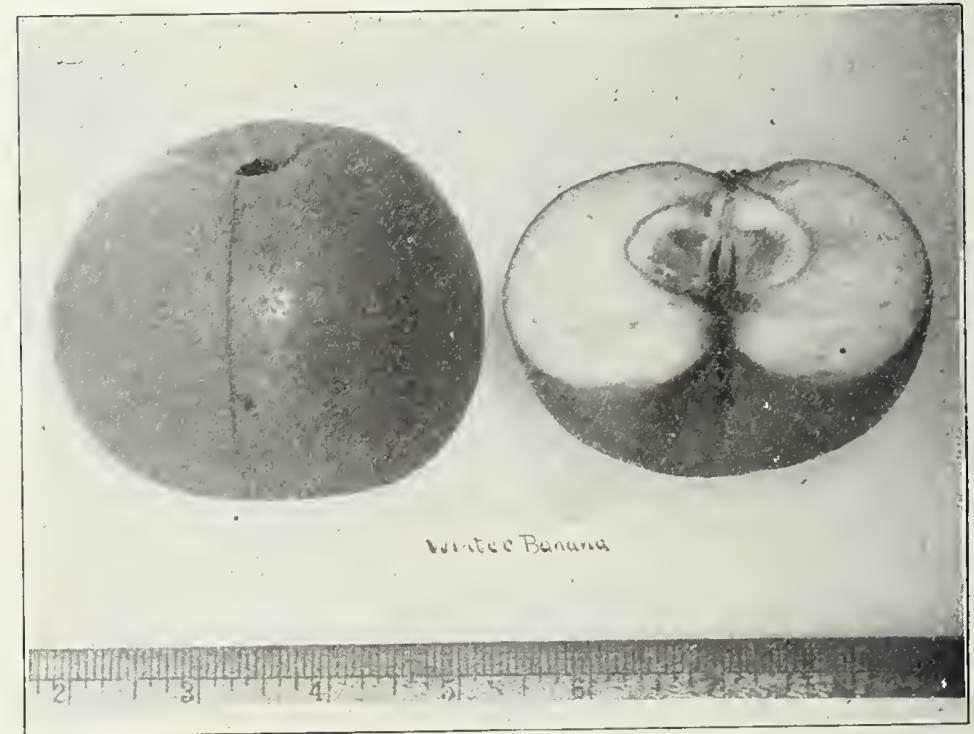

-Winter Banana Apple. 


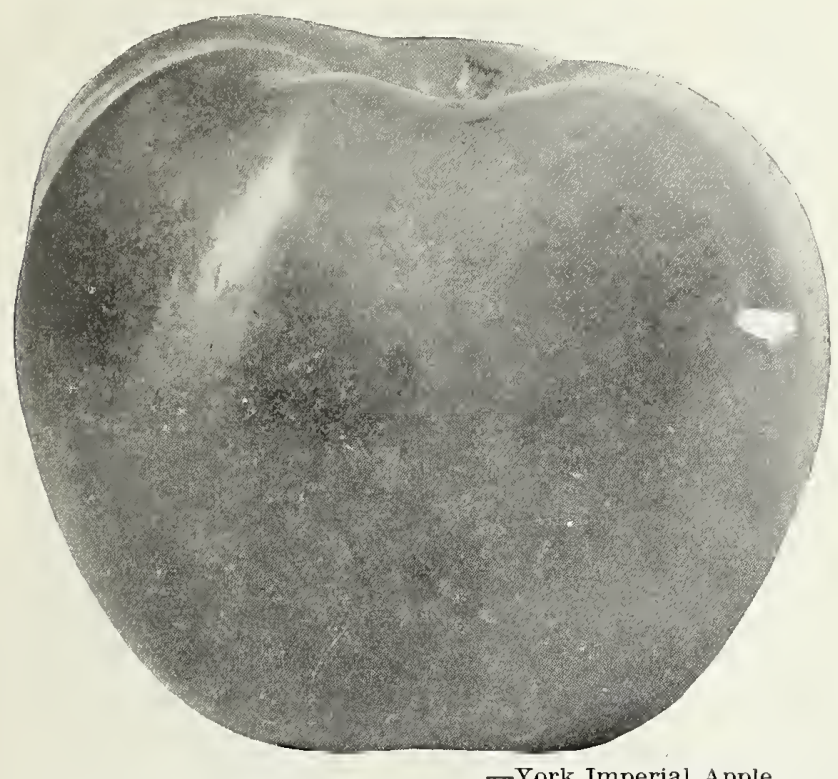

- York Imperial Apple.

Willow Twig--Tree good grower and good bearer; fruit globular; surface smooth, dull, greenish yellow, marbled and striped dull red; flesh greenish yellow, juicy; flavor acid; quality only good. Season Novem. ber to spring.

Winesap-An old favorite, one of the best; trce vigorous grower with spreading top; fruit medium, conical; surface smooth, bright or dark red on yellow ground; flavor rich, acid to sul acid; very desirable on account of its great productiveness and generally excellent quality.

Winter Banana-Has a delightful banana perfume; fruit keeps well till spring; the color is a striking red blush on a deep yellow ground; it is large size and very showy in appearance, roundish, inclining to conical; best quality.

Wolf Piver-An apple peculiarly adapted to the West on account of its extreme hardiness; very large

thrifty grower and good bearer; fruit medium, roundish; skin smooth, oily, mostly covered with dark red; flesh white, fine grained, juicy, sub-acid, good. November-January

White Winter Pearmain-Tree moderate grower, with spreading top; fruit medium, handsome when fair, but sometimes scabs badly; surface smooth, yellow, sometimes bronzed; flesh yellow, fine grained, tender juicy; flavor mild, sub-acid, very rich: quality best. Season November to January. and handsome, flesh whitish, breaking, pleasant and sub-acid. A good bearer. Season Novembcr to December.

York Imperial-Generally known and popular with many of our most experienced orchardists; tree moderate grower and productive; fruit large, lop-sided; surface smooth; color mixed, bright red on yellow ground; flesh yellowish, tender and juicy; flavor mild, subacid; quality very good. Season November till spring.

\section{CRAB APPLES}

The introduction of improved varieties of this beautiful fruit has made the planting of a few trecs very desirable for every family. They are universally desired for cooking, preserving and are especially valuable for cider.

Besides being useful, they are also very ornamental when in bloom, and alse when loaded with their highly colored fruits.

Florence-Tree hardy, a good grower and productive; fruit large; flesh yellow, acid, goor: for cooking and jelly.

Hyslop-Tree is a moderate grower, making a beautifully shaped, thrifty tree; bears young. Fruit large, nearly round, flattened at the ends; skin smooth; color dark rich red on yellow ground; flavor very good. One of the most beautiful fruits grown.

John's Crab-A good grower, hardy, very productive; fruit large to very large; in shape very much like the Jonathan apple; color a rich: dark red; flavor excellent; a good fruit to eat out of the hand. The best crab we know. Season Septcmber to November.

Martha-A seedling of Duchess of Oldenburg, which originated in Minnesota. Earlier than che Transcendent; very ornamental as well as a fine fruit; bears in profusion every year. September and October.

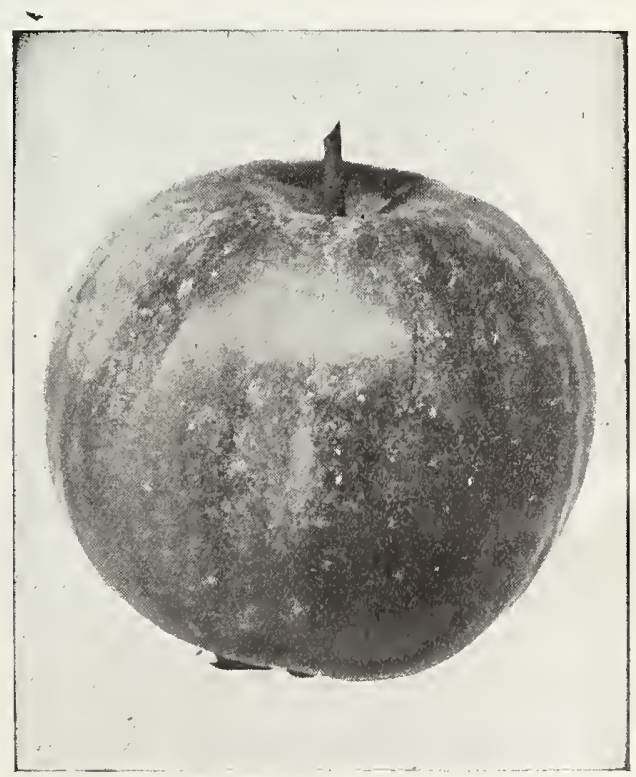

-Transcendent Crab Apple. 
Quaker Beauty-Tree one of the strongest growers; good bearer; quality good. Season October to January.

Transcendant-Tree strong grower, making a large, beautiful tree, and an early and abundant bearer, fruit large, round, skin smooth; color rich yellow, shaded with red; valuable for preserving and cooking. Season August and September.

Whitney's No. 20-Tree thrifty, upright grower. Fruit large; skin smooth, striped and splashed with carmine; flesh firm, iuicy and pleasant flavor. Season August. A productive bearer and considered one of the hest.

\section{PEARS}

The cultivation of this noble firuit is rapidly extending as its value is appreciated. The range of varieties is such that, like apples, they can be had in good eating condition from August until early spring. The melting, iuicy texture, the refined flavor, and the delicate aroma of the Pear give it rank above all other fruits except the grape. There seems to be but one drawback to the profitable cultivation of the Pear, either as standard or dwarf, and that is the "blight" which brings ruin to so many trees, and for which there is no known remedy.

But the geod prices and productive habits of the trees, their comparative freedom from other diseases and from insect enemies, make the Pear a desirable fruit to plant in a moderate way for market; and the high quality and many ways ili which it can be used, malie tine planting of a liberal supply for home use scarcely less than a necessity. Standard trees are hudded or grafted on seedling pear roots: dwarf trees are budded on Angers Quince roots.

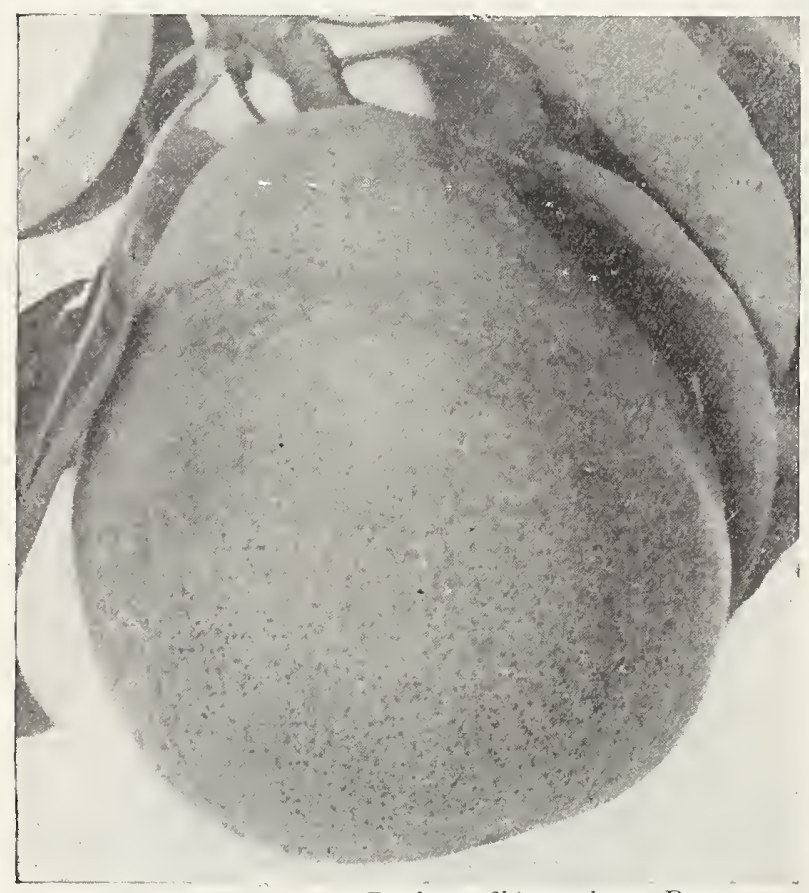

- Duchess d'Angouleme Pear.

STANDARD PEARS - Should be planted twenty to twenty-five feet apart. They will grow on almost any soil, provided the sub-soil is not too wet. Whenever this is the case the ground should be thoroughly underdrained. In very poor soil, a moderate top dressing of manure in the fall will be of advantage. When a tree is assailed by blight, cut off the part affected several inches below all appearance of the disease.

DWARF PEARS - Should be planted about eight or ten feet apart. They should be set so deep that the joint where the pear is united to the quince will be at least two inches below the top of the ground. At the time of planting and every spring thereafter they should be thoroughly pruned, shortening in the current year's growth about one-half, aiming to form a round and well proportioned head. The ground should be well cultivated and enriched by top dressing of manure in the autumn, and well mulched in the spring.

GATHERING PEARS-In order to retain the juice and best flavor, summer pears should be gathered at least ten days before they are ripe, and autumn pears at least two weeks before, and winter varieties before there is any danger of injury from frost.

THINNING THE FRUIT- Thien the trees are heavily laden the fruit should be thinned when about one-third grown, else the fruit will be pool' and the trees injured.

The letters "D" and "S" used in the descriptions of varieties, indicate favorable growth, either as "Dwarfs" or "Standards," or both.

Bartlett (S. and D.) -An old favorite, more generally known and highly esteemed than any other sort. Tree thrifty, upright grower; fruit large, irregular pyramidal; skin thin and smooth, clear yellow, sometimes with a faint blush on the sunny side; flesh white, fine grained, buttery, juicy, sweet; quality best. August and September.
Beurre de Anjou (S. and D.)-Tree good grower and bearer; fruit large, obtusely pyriform, sometimes nearly round; skin greenish, sprinkled with russet, somerimes shaderl with dull crimson; flesh whitish, melting, juicy. September to November.

Clapp's Favorite (S. and D.) - A splendid pear, resembling Bartlett, ripening a few days 


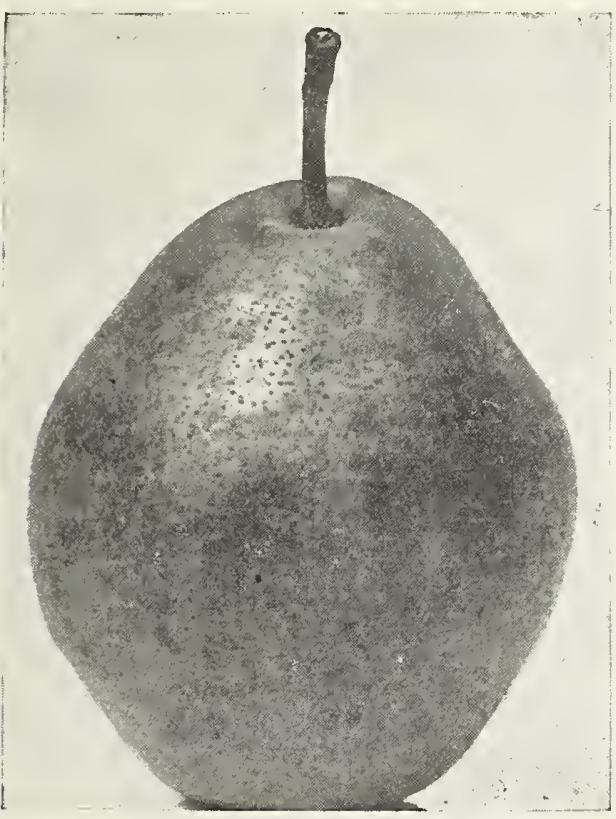

-Kieffer Pear.

earlier; a cross between that variety and Flemish Beauty. Fruit large; color ycllowish green, marbled with red in the sun: vinous, melting, rich. One of the best summer pears. August.

Duchess d'Angouleme (D.)-Sometimes planted as a standard, but an especial favorite as a dwarf. Tree vigorous and productive; fruit of the largest size, with an unfven, somewhat knobby surface; skin dull greenish yellow; a good deal streaked and spotter with russet; flesh white, buttery and very juicy, with a rich, excellent flavor. September and October.

Flemish Beauty (S)-Tree generally preferred as a standard; fruit large, skin a little rough, pale yellow mostly covered with patches of russet, be coming reddish-brown at maturity on the sunny side; flesh yellowish white, juicy and rich. One of the best. Septembcr.

Garber (S.)-Is kin to and very much like Kieffer, but is larger, of better quality, and ripens two or three weeks earlier; is as yellow as an orange; immensely productive; bears at three years from the nursery. A valuable market fruit.

Howell (S. and D.)Tree is a strong, free grower; fruit above medium size; skin light waxen yellow, often with a finely shaded cheek; flesh white, rather coarse, with a rich aromatic flavor. August and september.

Kieffer (S.) - Tree one of the strongest growers, with rich, glossy foliage; is not recommended as a dwart, but is highly recommended as less subject to blight than mos: others, though not in all cases free from blight. The Kieffer, by its good qualities of tree and fruit, has pushed its way to the front, so that today it is regarded as one of the most valuable kinds. Fruit large, golden yellow, blushed with red in the sun; flesh slightly coarse, juicy, melting. Tree a great bearer; fruit especially valuable for cooking and market.

Koonce (S.)-Medium to large, very handsome, surface yellow, one side covered with bright carmine, dotted with brown; very early, quality good, spicy, juicy, sweet.

Lawrence (S.)-Tree a moderate growth; early and good bearer; fruit medium size, obtuse pyriform; skin fine, light yellow, very thickly covered with minute brown dots; flesh whitish, somewhat buttery, with rich, aromatic flavor. One of the best early winter pears. October to December.

Lawson (Comet) ( $\mathrm{D}$. and S.) - Fruit large for so early a pear; sufficiently firm to insure its being a good shipper; of brilliant crimson color on vellow ground; flesh crisp, juicy and pleasant, yet like many of our mosi pop. ular market fruits, not of highest quality, but what it lacks in flavor is offset by its charming exterior. July.

LeConte (S )-Highly recommented; flesh melting, sweet, juicy and aromatic; good sort for the South. Ripens about with Bartlett.

Louise Bonne de Jersey (D.)-Tree especially desirable as a dwarf; vigorous grower, very productive; fruit medium size, pyriform, somewhat one-sided; skin smooth, glossy, pale green in shade, but brownish red in the sun; flesh greenish white, very juicy with a rich, excellent flavor. September:

Seckel (S. and D.)-Tree a moderate grower, said to be less subject to blight than most

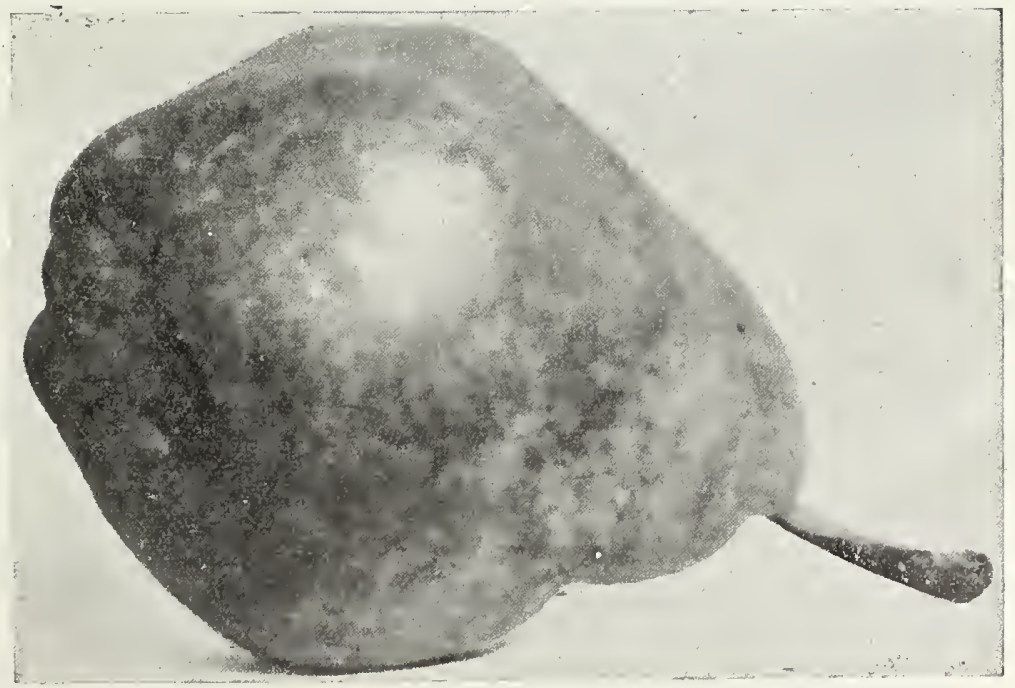

- Garber Pear. 
varieties; fruit small to medium; regularly formed; skin dull yellowish brown, with lively. red cheek; flesh whitish, buttery, very juicy and melting with a peculiarly rich, spicy flavor; a regular and abundant bearer. August to October.

Sheldon (S.) - Tree moderate glower and good bearer; fruit medium size or above, roundish oval; skin yellow or greenish russet with a richly shaded cheek; flesh melting, juicy. with brisk, vinous flavor. September-October.
Vermont Beauty (S.) - Tree hardy and vigorous; early and abundant bearer: fruit medium, yellow with a bright red cheek; flesh melting, juicy, sprightly and of best quality. September.

Wilder (S.)-Size medium; greenish yellow with a brownish red cheek and numerous dots; flesh white, fine grained, melting, excellent; about three weeks earlier than the Bartlett.

\section{CHERRIES}

Cherry culture has been a success when proper attention has been given to the selection of varieties and their culture. The hardy, thrifty varieties of the Morello type may be freely planted with confidence of profitable results. The cherry tree should be planted in a naturally dry soil or the soil should be well drained so water may not remain near the roots for any considerable time. Cherries are now generally worked on Mahaleb, a stock that does not throw up sprouts from the roots.

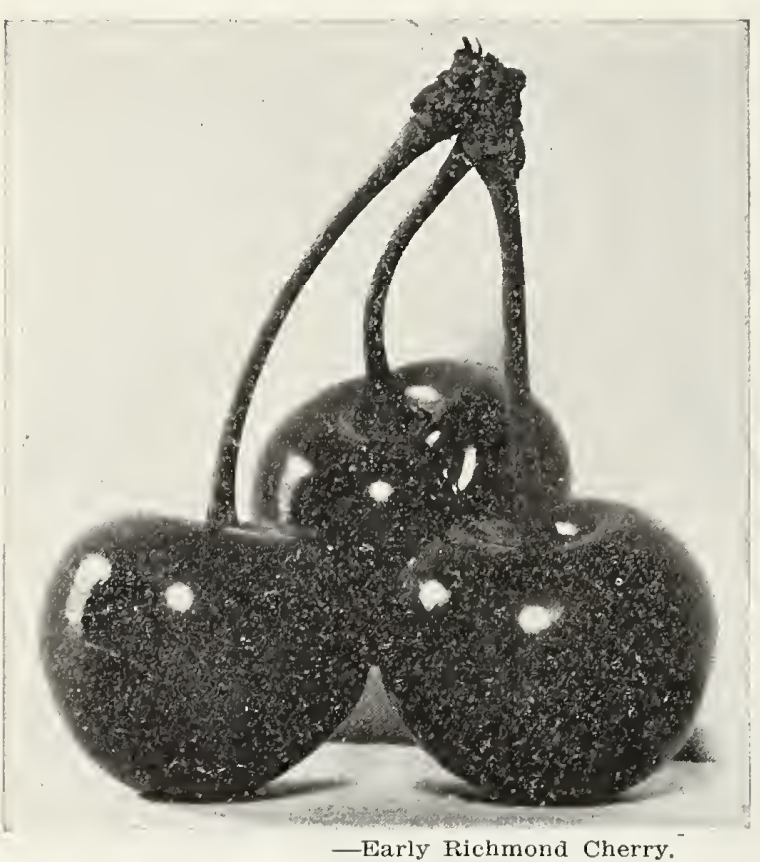

Baldwin-Tree an upright, vigorous grower, forming round head; leaves large and broad; bloom pure white, changing to pink; fruit large, almost round, very dark transparent wine color; flavor slightly acid, yet the sweetest and richest of the Morello type; stems lather large, of medium length and generally in pairs.

Black Tartarian-Very large, bright purplish black; half tender, juicy, very rich, excellent flavor, productive. Free. Ripens first to middle of July.

Dyehouse-This variety partakes both of the Morello and Duke, wood and fruit; a very early and sure bearer; ripens a week before Early Richmond; of better quality and quite as productive. Free. May-June.
Early Richmond-Everywhere the most popular; tree strong, thrifty grower, making a large symmetrical head; fruit medium size, dark red, melting, juicy, sprightly acid flavor and especially valuable for cooking purposes; tree an early and abundant bearer. Season last of May and first of June.

English Morello-Tree moderate grower; hardy, great and early bearer. The most valuable of the late varieties; fruit large, round, skin dark red, oecoming nearly black when fully ripe; flesh dark red, tender, juicy, and of a pleasant sub-acid flavor when fully ripe. Season July.

Governor Wood-One of the best of all varieties of the sweet cherries. Tree makes a fairly healthy growth; fruit large, rich, light yellow with a red chcek; juicy and sweet.

May Duke-One of the best of cherries, and one of the most popular among experienced fruit growers in Kansas; fruit roundish, obtuse, heart-shaped, growing in clusters, and when fully rine of a rich dark red; flesh reddish, tender and melting, very juicy and when fully ripe of a rich, excellent flavor. Season May and first of June.

Montmorency-This is a cherry of Early Richmond class, somewhat larger and about ten days later; a strong upright growing tree and good bearer, and is by experienced horticulturists considered one of the most valuable varieties.

Olivet-Fruit large, globular, a shiny deep red sort; ripens early in June, and retains its excellence longer than most others.

Ostheim-A perfectly hardy, very late blooming cherry from Germany. Immensely productive; fruit heart-shaped, nearly black when ripe; juicy and rich. Has been tried in 
Wragg-Originated in Iowa. Medium to large in size, long stem, dark purple when fully ripe. A variety well adapted to the high latitude and prairie regions of the northwest. the West and succeeds. Valuable late cherry. July.

\section{PLUMS}

The Plum tree, like the Pear and other finer fruits, attains its greatest perfection on heavy clay soil, being entirely free from disease. The curculio, a small dark brown beetle, often stings the fruit, causing it to drop off; but proper spraying will secure a crop of this splendid fruit everywhere. The demand for Plums is constantly increasing and they can be grown with much profit. For home use the fruit should be allowed to remain on the trees until fully ripe, but for shipping they must be pirked earlier.

There are several distinct classes of Plums and a long list of varieties, but we mention here only the best of each class, and such as we think will give the planter the best returns.

\section{EUROPEAN VARIETIES}

Bradshaw-Fruit very large; aark vio let red; flesh yellowish green; juicy and pleasant, productive; vigorous. Middle of August.

Coe's Golden Drop-Large and handsome; light yellow: firm, rich and sweet; one of the best lats plums; moderate. September.

Fellenburg (Italian Prune)-A fine late plum, oval, purple; flesh juicy and delicious; parts from the stone; fine for drying; tree very productive; free. September.

German Prune--A large, long, oval variety; much esteemed for drying; color dark purple; of very agreeable flavor; vigorous. September.

Gueii-Large, oval; dark purple; flesh firm, but a little coarse; sub-acid. A valuable sort for cooking and market.

Imperial Gage - Rather large, ovaI; greenish, flesh juicy, rich and delicious; tree a vigrrous grower and very productive. One of the best Plums of its class.

Lombard-Perhaps the best of the European varieties now in cultivation; tree vigorous, hardy and productive; fruit of medium size, roundish, oval, slightly flattened at the ends; skin delicate violet red, paler in shade; flesh deep yellow, juicy and pleasant. Season August.

Moore's Arctic-Originated in Maine, and celebrated for its remarkable hardiness, great bearing qualities and freedom from curculio; fruit grows in large clusters, large, dark purple; flavor very fine, both foi preserving and dessert. A long keeper.

Pond's Seedling (Hungarian Prune)-Very large, dark red; juicy, sweet; very productive; good shipper. A profitable variety for both home and distant markets. Ripens in September.

Reine Claude-Greenish yellow; flesh a pale green; firm, juicy, sugary and of fine qual-

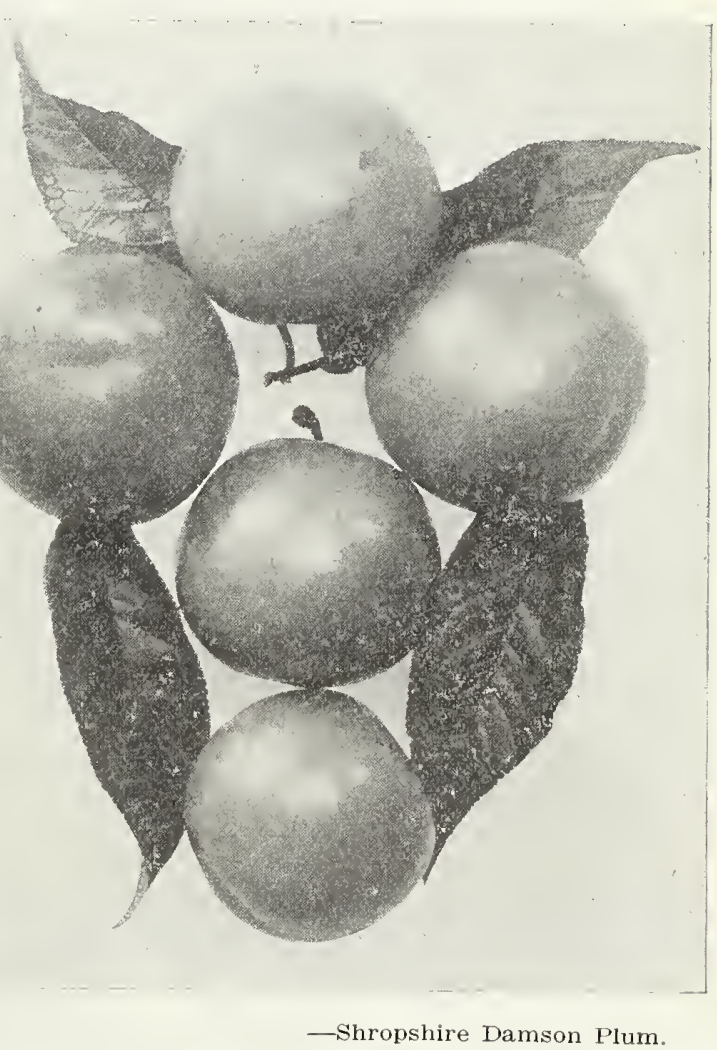

ity. A very productive variety. Season August.

Shipper's Pride-'Lhis plum originated in northwestern New York, near the shore of Lakc Ontario and has never been known to freeze back a particle in the severest winters. Size large, color dark purple, flesh firm and excellent quality. First of Sentember.

Shropshire Damson-A plum of fine quality; rich dark purple; flesh amber colored; juicy and sprightly; very productive. Ripens in September.

Yellow Egg-A large and beautiful egg-shaped yellow plum; a little coarse, but excellent for cooking; tree a free grower and very productive. Season August. 


\section{NATIVE VARIETIES}

DeSoto-Medium, bright red, sweet, rich, of fine quality. Extremely hardy and productive.

Mariana - Fruit large, round, bas a singular'ly rich red color and most magnificent appearance; is not easily blown off by winds; skin rather thick, stone small, quality excellent; good for shipping and market. July. Free. A good growel.

Pottawatomie--Perfectly hardy and an immense early annual bearer; fruit is yellow, overspread with a bright pink and prominent white dots; flesh yellow, luscious, good. Ripens in July.

Weaver-Fruit large, purple with blue bloom, of good quality; a constant and regular bearer; tree hardy and thrifty grower.

Wild Goose-The most popular of plums with some fruit growers; tree a vígorous upright grower; fruit medium to large, rich golden yellow, richly shaded with red; flesh yellow, juicy; flavor rich and good.

Wolf-Fruit nearly as large as Lombard and a perfect freestone; quality superb for cocking and for serving with sugar; tres a good grower, hardy and is becoming very popular wherever known, promising to lead all other plums. August.

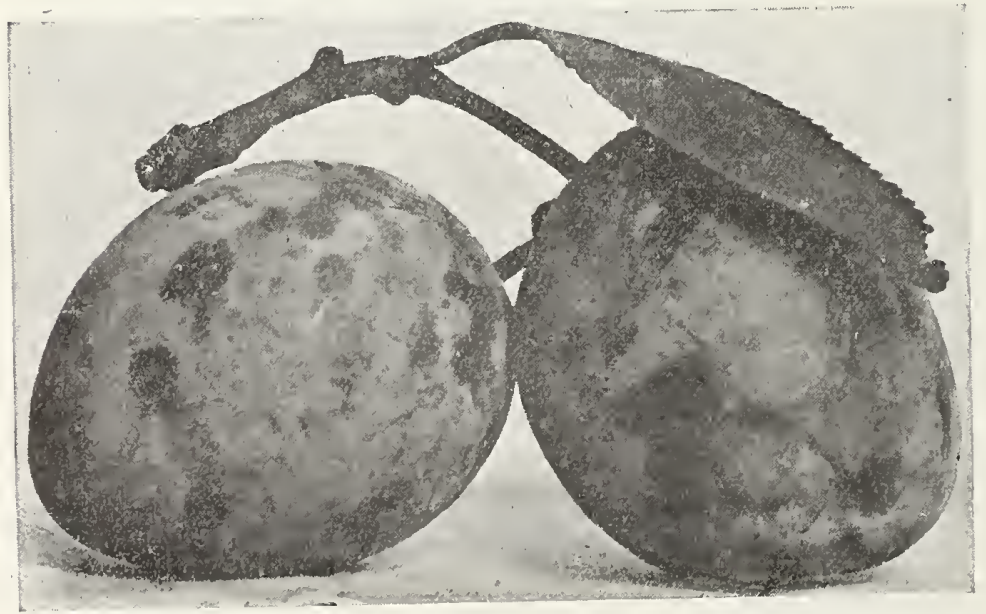

\section{JAPAN VARIETIES}

A unique class of plums, of great beauty and productiveness. The fruit is exquisitely perfumed, with a charmingly attractive bloom. Trees are exceedingly ornamental, with smooth branches and rich, light green foliage, and quite distinct from other varieties, early and prolific bearers. The flesh is so firm and meaty that they can be safely shipped long distances, and kept for a long time in excellent condition.

Abundance-One of the best of the Japan plums; tree a strong grower and an early, and abundant bearer; fruit large and handsome; oblong, tapering to the point, skin bright cherry red, with a heavy bloom; flesh is orange yellow, melting, rich and highly perfumed. July.

Burbank-The best of all Japan sorts of plums; nearly globular, clear cherry red with a thin lilac bloom. The flesh. is a deep yellow color, very sweet, with a peculiar and very agreeable flavor; tree vigorous, with strong upright shoots, large broad leaves; commences to bear usually at two years. It blooms late a $\mathrm{nd}$ consequently is more likely to escape the late spring frost. 
Prunus Simoni - This remarkable plum came from Northern China; fruit large, cinnamon red color, the flesh is firm, rich, sweet, aromatic and delicious flavor; tree an upright grower, long, hanging leaves, distinct July.

Red June-Fruit medium size, bright red; one of the best of the early plums.

Satsuma Blood-A fine large plum of the Oriental class; flesh solid, of a purplish crimson color from pit to skin, juicy and of fine quality; pit exceedingly small, very little larger than a cherry stone; tree a strong vigorous grower.

Wickson-Tree a s' rong upright grower and very productive; fruit large, handsome, deep maroon red, with a white bloom; stone very small: flesh fine, sugary and delicious.

\section{PEACHES}

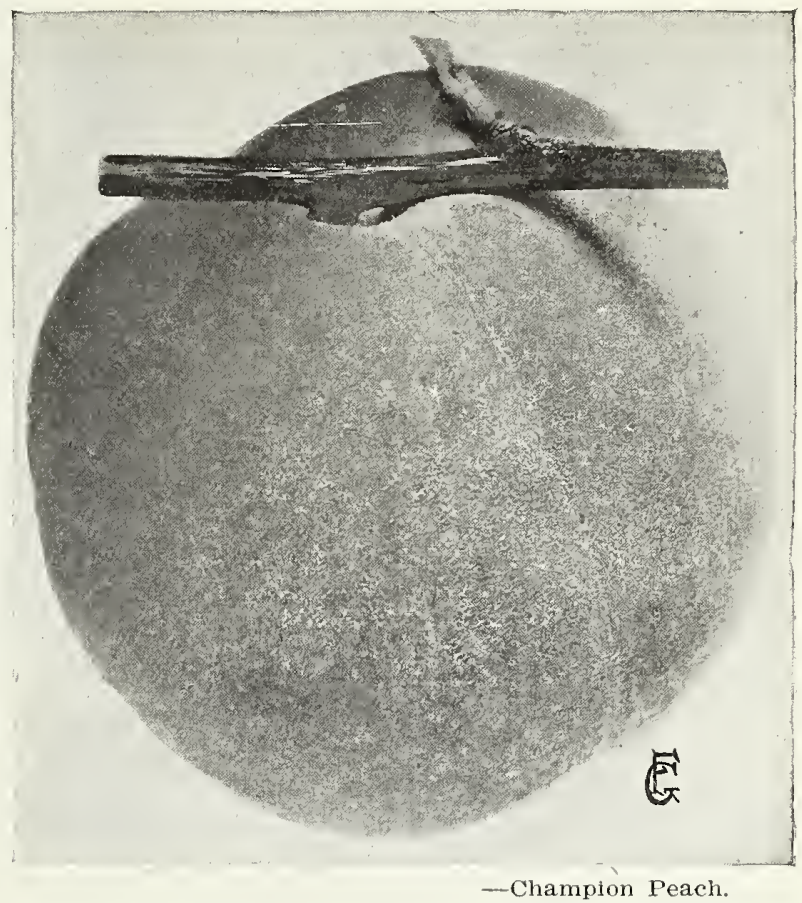

Peach trees should be planted 16 or 18 feet apart. To secure healthy, vigorous and fruitful trees and fine fruit, the following points should be well attended to: (1) Keep the ground clean and mellow; (2) Keep the heads low-the trunk should not exceed 3 feret in height; (3) Give them an occasional dressing of wood ashes; soap suds also are good; (4) Prune Every spring, shortening the shoots of the previous year's growth. This keeps the head round, full and well furnished with bearing wood. Cut weak shoots back about one-half, and strong ones about one-third, but see that there is left sufficient supply of fruit buds. Sickly and superfluous shoots should be cut out clcan. The fruit is born on wood of last season's growth, hence the necessity of keeping up a good supply of vigorous annual shoots all over the tree. Young trees should be well mulched every spring.

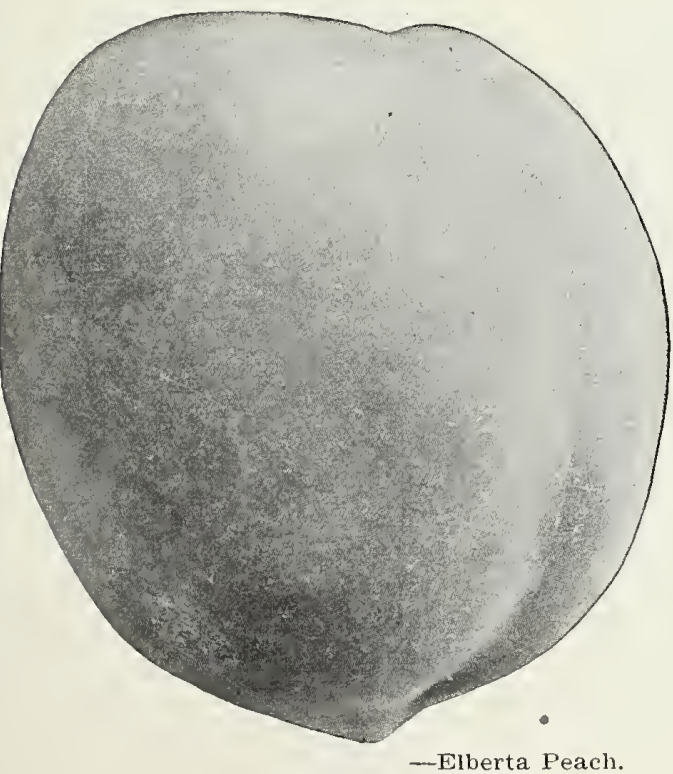

Arkansas Traveler-Said to ripen earlier than Amsdell, of which it is a seedling. Fully equal to it in every respect.

Alexander - Large, well-grown specimens measuring \& inches in circumfer ence; handsome and regular in form, with deep maroon shade, covered with the richest tint of crimson; rich and good in quality, with a vinous flavor; adieres to stone; should remain on tree until fully ripe Late June.

Amsden-Fruit medium size, color red, beautifully shaded and mottled with a very dark red, nearly covering the greenish white ground; flesh white, with a delicious flavor when ripened on the tree. June 15 to 30 .

Elood Cling-A variety of the old Indian peach. Fruit very large, form nearly round, skin dark purplish red, flesh very red; juicy and good. September and October.

Bokara-Raised from seed received from Bokara, Asia. The hardiest peack known; has been in bearing for several years in 
central Towa, and produced fruit after 28 degrees below zero. Fruit measured over 7 inches in circumference. Yellow, with red cheek; skin tough, flesh of good quality, a perfect freestone. Prof. Budd says: "They are 30 per cent hardier than the old strain of peacles."

Carman-Large, resembles Elberta in shape; color cream-white or pale yellow with deep hlush; skin very tough, flesh tender, fine flavor and quite juicy; ripens with Early Rivers; one of the hardiest in bud, in shipping qualities and freedom from rot unsurpassed. Promises to stand at the head for a general long dis tance profitable market variety, in quality ranking superior to anything ripening at the same time. August.

Champion-Fruit large, beautiful in appearance; flavor delicious, sweet, rich and juicy: skin creamy white, with red cheek; freestone. The peculiarity of this great acquisition is its hardiness. It stood a temperature of 18 degrees below zero in the winter of 1887-9, and produced an abundant crop the following season; and again in 1890 produced a full crop, when the peach crop was a universal failure. Aug. 15.

Crawford's Early-This beautiful yellow peach is highly esteemed for market rurposes. Fruit very large, oblong: skin yellow, with fine red cheek; flesh yellow, juicy, sweet and excellent; productive, free. July 15 th.

Crawford's Late-Fruit of the largest size; skin yellow, or greenish yellow, witl duli red cheek; flesh yellow; productive; one of the best; free. Iate August and September.

Crosby-Medium size, roundish, with distinct seam on blossom end; skin light golden yel. low and very downy; flesh bright yellow and

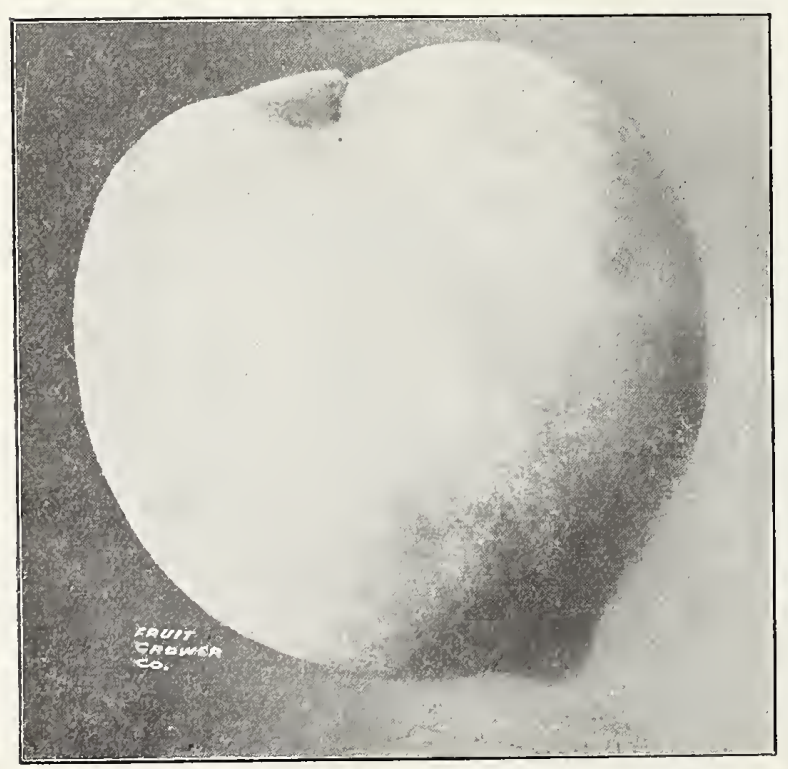

- Heath Cling Peach. rather firm. Ripens between Varly and Late Crawford. Tree of rather dwarfish habit. Has won special favol on account of great hardiness. A recent introduction, that has attracted very wide attention on account of its disposition to produce good crops in "off years," when other varieties usually fail.

Early Rivers-Large, light straw color, with delicate pink cheek; flesh juicy and melting, with very rich flavor. First of July.

Early York-Large, white, with red cheek, fine grained, very juicy, rich and delicious; vigorous and productive; one of the best; free. First of August.

Elberta-Very large and well colored; all things considered, the finest yellow freestone in cultivation; no one can go amiss by planting it. Fruit perfectly free from rot; one of the most successful shipping varieties. August 20.

Family Favorite-Free; seedling of Chinese Cling, of better color; clear, waxen complexion, with blush; large, firm, valuable tor shipping, canning or drying; prolific. Late July.

Fit $z$ gerald-Originated on the north shore of Lake Ontario and in that cold region the original tree bore five successive crops. Tree will bear the second year from planting. The fruit is large, skin bright yellow, suffused with red, flesh deep yellow and of the best quality; seed very small. Freestone. July 20 th.

Foster-Large, deep orange red, becoming very dark red on the sunny side; flesh yellow, very rich and juicy, with sub-acid flavor; earlier than Early Crawford; very handsome. Free.

Globe-An improvement on Crawford's Late; fruit large, globular, of a rich - golden yellow with a red blush; flesh yellow, juicy. August. 
Greensboro-Origin, North Carolina. Ripens with Alexander, but much larger; round; flesh white, very juicy, of good quality; bright red over yellow, highly colored in the sun. A promising market variety.

Hale's Early-Fruit medium size; skin clear, smooth, white, delicately marbled with bright and dark red on the sunny side; flesh very melting, juicy and highly flavored. July 10th to $20 \mathrm{th}$.

Heath Cling-Large, oblong, creamy white, slightly tinged with red in the sun; very tender, juicy, melting; very rich and luscious. September 15th.

Lemon Cling-Large, oblong, having a swollen point, sirular to a lemon; skin yellow, with red cheek; flesh yellow, firm, juicy and sweet; tree a fine grower. August.

Lemon Free-Almost lemon shape and pointed at the apex, color a pale yellow when ripe; it is of large size, the finest specimens measuring over twelve inches in circumference, of excellent quality; ripens after the Late Crawford; is immensely productive.

Mayflower-The earliest peach known. Large size, bright red all over and fine flavor. 'Tree is a strong, thrifty growel and very productive, so that to secure the best results the fruit must be thinned. A good shipper and a valuable market variety:

Mountain Rose-Large, red; flesh white, rich, juicy, excellent; one of the best early peaches, ripening with Hale's Early, and much larger and finer than that variety; should be in every collection. July.

Old Mixon Cling-Large, pale yellow, with red cheek; juicy, rich and liighly flavored; one of the best clingstone peaches. August 20th.

old Mixon Free--Large, pale yellow, with red cheek; rich and good, one of the best. August.

Salway-Fruit large, roundish, deep yellow, with a deep marbled brownish red cheek; flesh yellow, firm, juicy, rich and sugary; a late showy market sort; free. Last of September.

Smock-Fruit large, oval, skin orange yellow, mottled with red, a good market sort. September 15th.

Sneed-The most remarkable early peach yet introduced; it ripens a week to ten days earlier than Alexander, belongs to an entirely different type from Alexander and Hale's Early; it is very distinct in tree and fruit, belonging to the Chinese Cling type; size medium, color white, with flush on cheek.

Stump the World-Very large, roundish; skin white, with a bright red cheek; flesh white, juicy and good. Last of September.

Triumph-Earliest yellow flesh peach, with good eating and shipping qualties. Ripens with Alexander, blooms late; sure and abundant bearer; strong, vigorous grower. Fruit good size, yellow, with red and crimson cheek.

Wager-Very large, more or less colored on sunny side; juicy and of fine flavor; free. First to middle of August.

Wonderful-Originated in New Jersey, large,

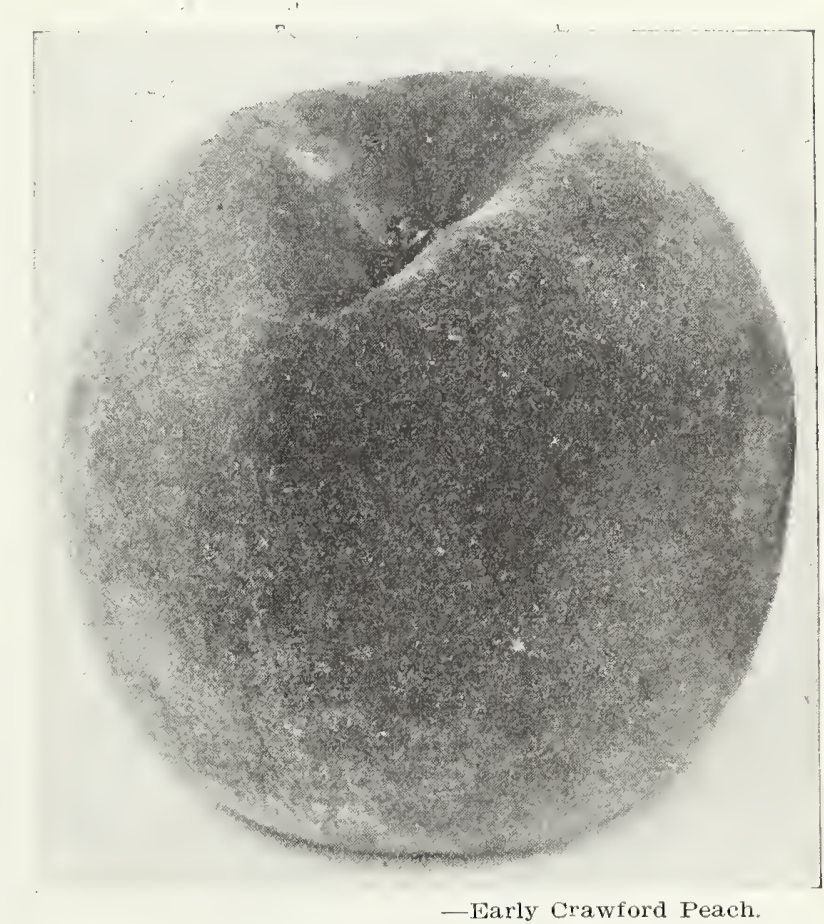

uniform in shape and size. color rich golden yellow, overspread with carmine and crimson; flesh yellow, highly flavored and firm, bright red at pit, which is small and parts freely from the flesh. Ripe in October and keeps well.

\section{APRICOTS}

A delicious fruit of the plum species, valuable for its earliness. It is liable to be attacked by curculio, and requires the same treatment as the plum; it bears immense crops; ripens in July and August.

Alexander-An immense bearer; fruit of large size, oblong, yellow flecked with red, flavor sweet and delicious; tree hardy; one of the best. July 1 st.
Alexis-Large to very large; yellow with red cheek; slightly acid, but rich and luscious; tree hardy and an abundant bearer. Ripens July 15 th. 
Early Golden-Small, color pale orange; it is juicy and sweet; as hardy as the Russian apricot, and productive; vigorous. Ripens first of July.

Gibb-Medium size; yellow, sub-acid, lich and juicy; the best early sort, rupening with the strawberry.

Harris-A new variety, recommended for its good bearing qualities and extreme hardiness. It was brought into notice by orchardists at Geneva N. Y., who prize it highly as a market variety. It is equal in size and quality to the best cultivated sorts, and should take the place of the Russian Apricot.
J. L. Budd-Of large size; white, with red cheek; flavor sweet, juicy, extra fine; a hardy, strong grower and profuse bearer; the best late variety. August 1.

Mason-Tree a good grower and productive; fruit large, sweet and very fine. We plant it in preference to all others.

Moorpark-One of the largest; orange, with a red cheek; firm, juicy, with a rich flavor; very productive; vigorous. July.

Superb-Medium size, roundish-oval, smooth, light salmon with numerous red or russet dots; flesh yellow, iirm, sub-acid and good; tree hardy and productive.

\section{QUINCES}

The Quince is, of late, attracting a great deal of attention as a market fruit. The tree is hardy and compact in growth, requiring but little space; productive, gives regular crops and comes early into bearing. The fruit is much sought after for canning for winter use. When put up in the proportion of about one quart of quinces to four of other fruit, it imparts to them a most delicious flavor. It flourishes in any good garden soil, which should be kept mellow and well enriched. Prune all the dead and surplus branches, and thin out the fruit if bearing too freely.

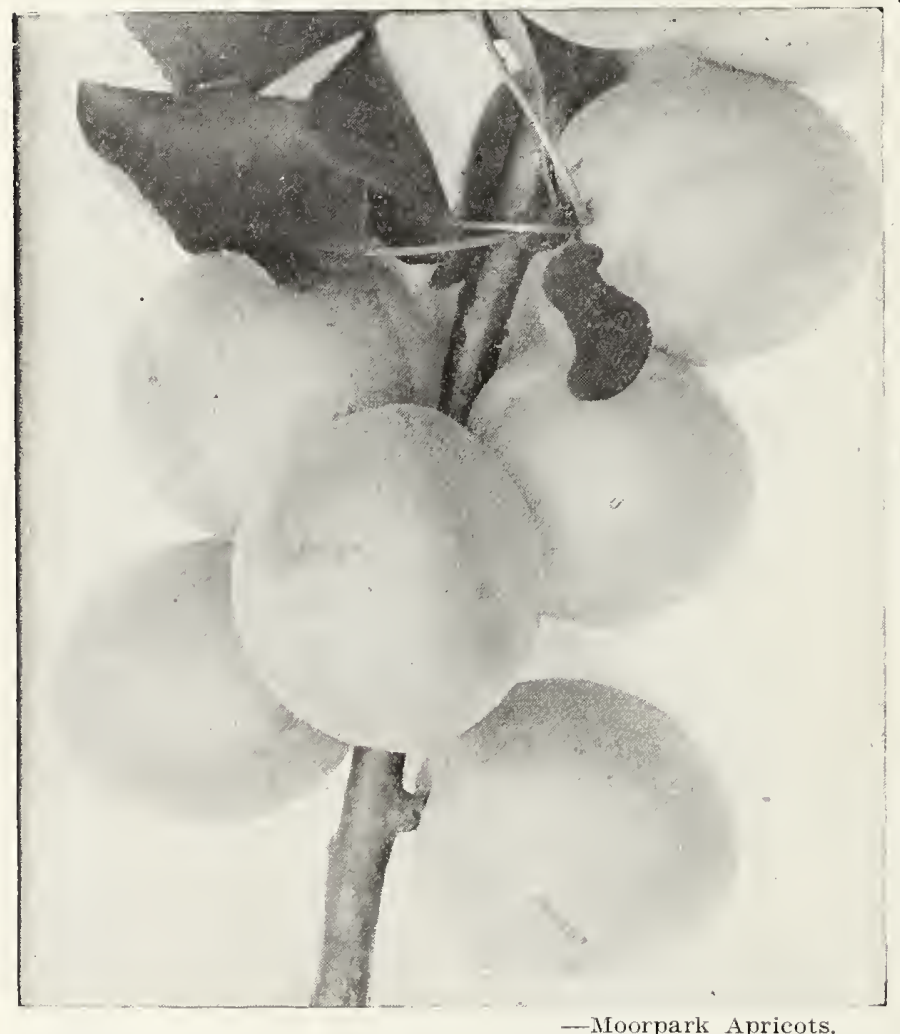

Missouri Mammoth-The largest Quince in cultivation. Brought into notice in the vicinity of Kansas City, Mo., where ic is fruited extensively, and is attracting great attention on account of its being large in size, perfect in shape, very rich and aromatic; tree vigorous, productive, early bearer, free from blight.

\section{NECTARINES}

A most delicious, smooth-skinned fruit, which thrives wherever peaches will grow, but it is liable to be stung by the curculio, and requires the same treatment as plums.

Boston-Large, deep yellow, with a bright blush and mottlings of red, sweet and peculiar pleasant flavor; freestone; the largest and most beautiful variety known; hardy and productive; vigorous. August.

\section{MULBERRIES}

Downing's Everbearing - Color blue-black; flesh juicy, rich sugary, with a sprightly, vinous flavor; tree ornamental as well as fruitful.
Apple or Orange-Large, roundish; bright golden yellow; cooks tender and is of very excellent flavor. Valuable for preserves or flavoring; very productive; the most popular and extensively cultivated variety. October.

Champion-The tree is a strong grower, a prolific and constant bearer, the truit averaging larger than the Orange; more oval in shape; quality is equally as fine and a longer keeper.
Hick's Everbearing-Wonderfully prolific. Said to be superior to Downing.

New American - Fruit of the largest size; black, delicious in flavor; an attractive lawn tree, with very large leaves; of rapid growth; hardy.

Russian-This makes a good shade and ornamental tree; growing full and symmetuical; holding its leaves late in the autumn. It is a. 
very rapid grower, bears fruit at two or three years of age, and every year. Color of the fruit varies some, but is generally black; very valuable.

\section{CHESTNUT \\ American Sweet}

Among our large collection of ornamental native forest trees the Chestnut is unrivaled for beauty. When grown in the open ground it assumes an elegant symmetrical form. The foliage is rich, glossy and healthy, and the whole tree is covered in early summer with long, pendent, tassel-like blossoms. It is especially desirable for its nuts, which it bears profusely a few years after transplanting. The Chestnut thrives well in any soil except a wet one. When nursery-grown, bears transplanting well, and once established grows rapidly and soon comes into bearing.

\section{GRAPES}

Too much cannot be said in praise of the Grape. It is one of the best and most popular fruits, delicious for eating, especially desirable for cooking and preserving, and everywhere in large demand.

The vine comes quickly into bearing, yielding fruit usually the second year after planting, requires but little space, and when properly trained, is an ornament to the yard, garden or vineyard.

Work the ground deep for grape vines, and plant a little deeper than they were in the

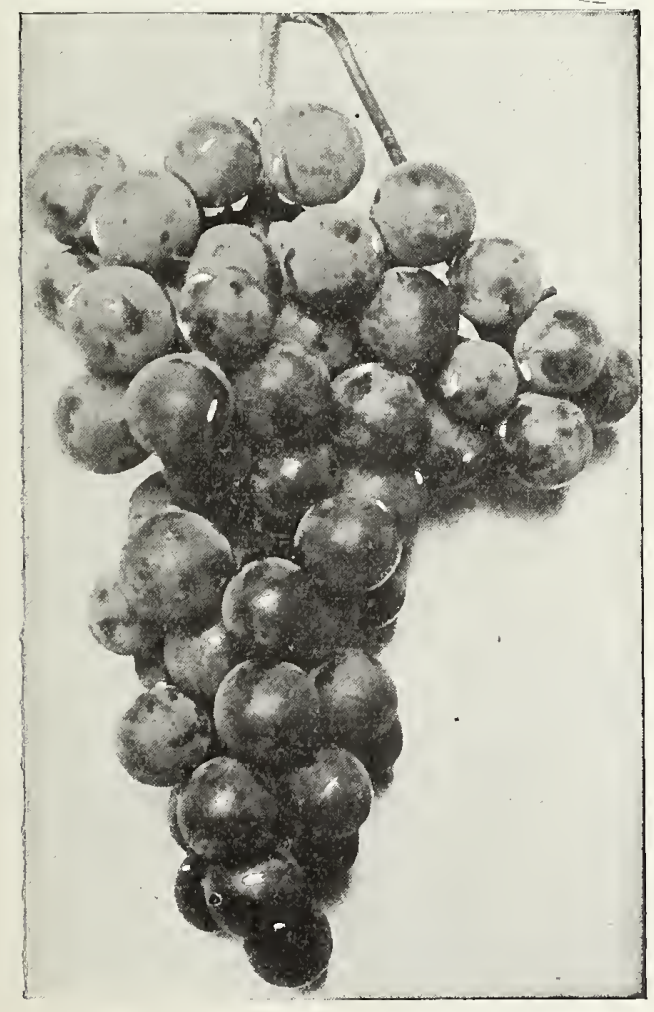

-Niagara Grape.

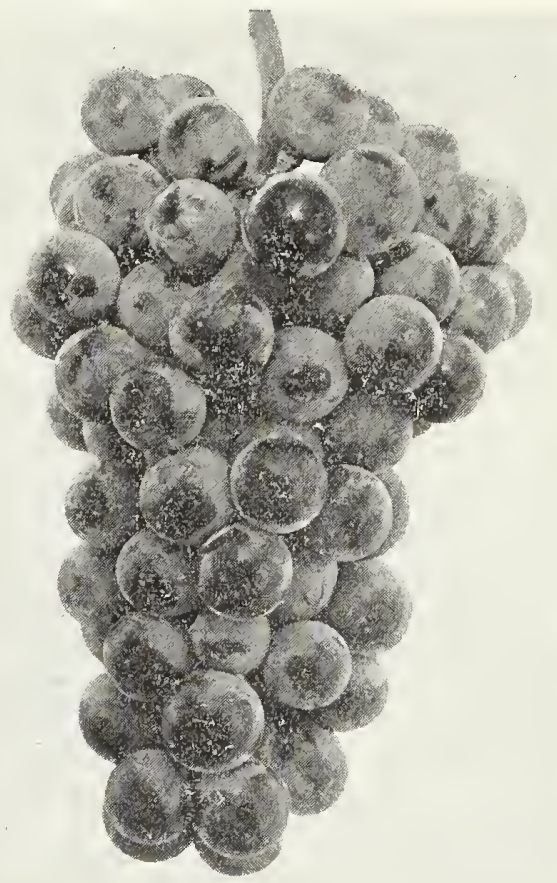

-Brighton Grape.

nursery. Make the rows 8 feet apart and plant the vines 6 to 8 feet apart in the rows.

\section{BLACK GRAPES}

Campbell's Early-Cluster large, shouldered, moderate compact; stem large, long and strong; berry large, nearly round, slightly elongated; black, with profuse light blue bloom; skin thin, with slight pulpiness; flesh translucent, very tender and very juicy; flavor sweet; aroma delicate, not foxy; quality best for both markei and dessert. Season early.

Concord-A most popular variety, universally healthy, vigorous and productive; flesh somewhat buttery, moderately juicy and sweet; bunch large, nearly black, with bloom; early.

Ive's Seedling-Vine healthy, strong grower; fruit bunch medium to large; flesh siveet and juicy, but foxy and puffy; a desirable market grape on account of its good keeping qualities; it colors early, but ripens later than the Concord.

Moore's Early-Seedling of Concord, combining the vigor, health and productiveness of Concord, and ten days earlier; in quality hardly to be distinguished from Concord. A valuable acquisition. Bunch large, berries very large, black.

Worden-Seedling of Concord, which it greatly resembles in appearance and flavor; but the berries are larger. The fruit is said to be better flavored, and to ripen several days earlier. These qualities give it the foremost rank amorg the native Grapes.

\section{RED GRAPES}

Agawam-Large, round, early and of great vigor of growth; rich, high, peculiar aromatic flavor. Considered by Mr. Fogers as the best of his strictly red hybrids. 
Brighton-A cross between the Concord and Diana Hamburg; bunches large, berries of medium size, flesh sweet, tender and of the highest quality. Ripens early.

Catawba-Well known as the great wine grape of Uhio, Kentucky, etc, bunches large and loose, berries large, of a colpery-red color, becoming purplish when well ripened; where not subject to rot, holds its own as one of the best varieties.

Delaware-Fiolds its own as one of the finest grapes. Bunches small, compact, shouldered; berries rather small, round; skin thin, light red; flesh very juicy without any hard pulp, with an exceedingly sweet, spicy and delicious flavor; vines moderately vigorous, very hardy and productive; ripens before Concord.

Salem-Bunches large and compact; berries large, round; flesh tender, juicy, sprightiy, sweet and good; ripens soon after Delaware.

Woodruff-Very hardy, rank grower, and very healthy; the fruit is large in bunch and berry; attractive, shouldered, sweet and of fair quality. Desirable as a market variety; ripens soon after Concord

\section{WHITE GRAPES}

Moore's Diamond-The vine is a good grower, free from mildew, productive, bunches large and compact; color a yellowish green; berries juicy, tender, good.

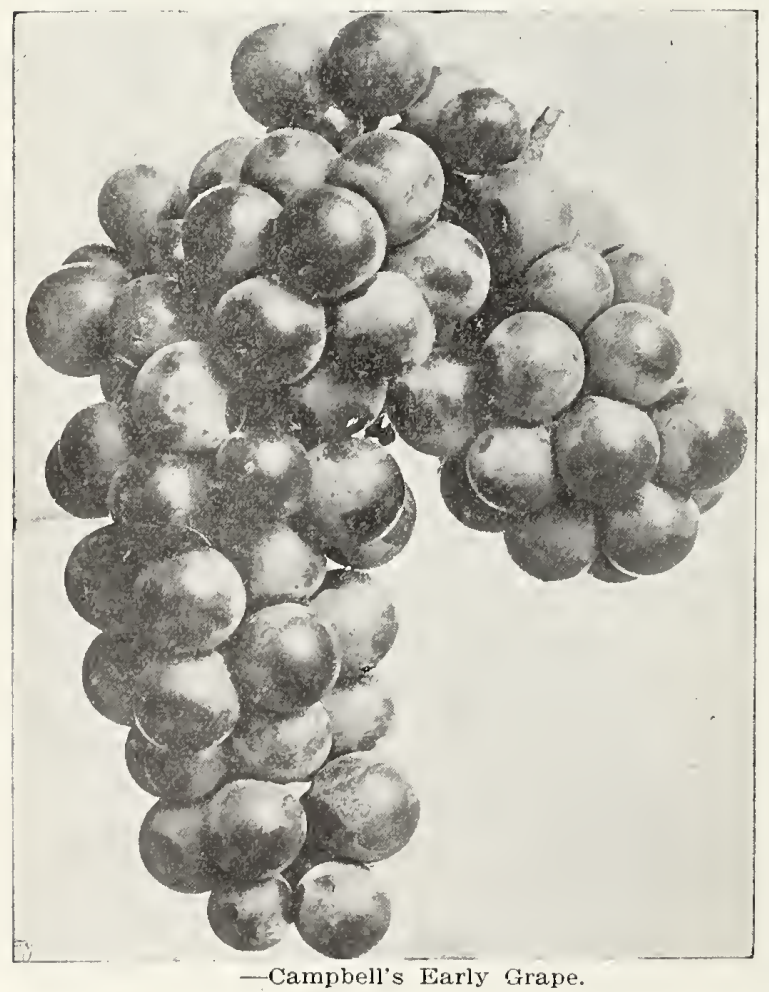

Martha-A seedling from the Concord, which it resembles in growth and hardiness; bunch of good size and berry large, of pale green or light color; sweet, juicy, sprightly; ripens with Concord.

Niagara-Bunch medium to large, compact, sometimes shouldered; berries large, roundish, uniform; skin thin but pale yellow when fully ripe, with a tough, pale green at first, changing to thin whitish bloom; flesh slightly pulpy, tender, sweet before it is fully ripe; vine vigorous, healthy and productive; ripens with the Concord.

Pocklington-The vine is thoroughly hardy, both in wood and foliage; a strong grower, never mildews in vine or foliage; called a white grape, but the fruit is light yellow, clear, juicy and sweet to the center, with little or no pulp; bunches very large; sometimes shouldered; berries round and very large and thickly set; quality, when fully ripe, superior to the Conrord; ripens with the Concord.

No fruit land or plot of ground should be permitted to be devoid of at least a grape arbor. The luscious grape richly rewards for the space given over to it. 


\section{GOOSEBERRIES}

In order to produce large, abundant crops of Gooseberries it is necessary to manure heavily and prune closely. The English varieties do not require much pruning. Mildew is prevented by close planting and heavy mulching. Plant 3 to 4 feet apart each way.

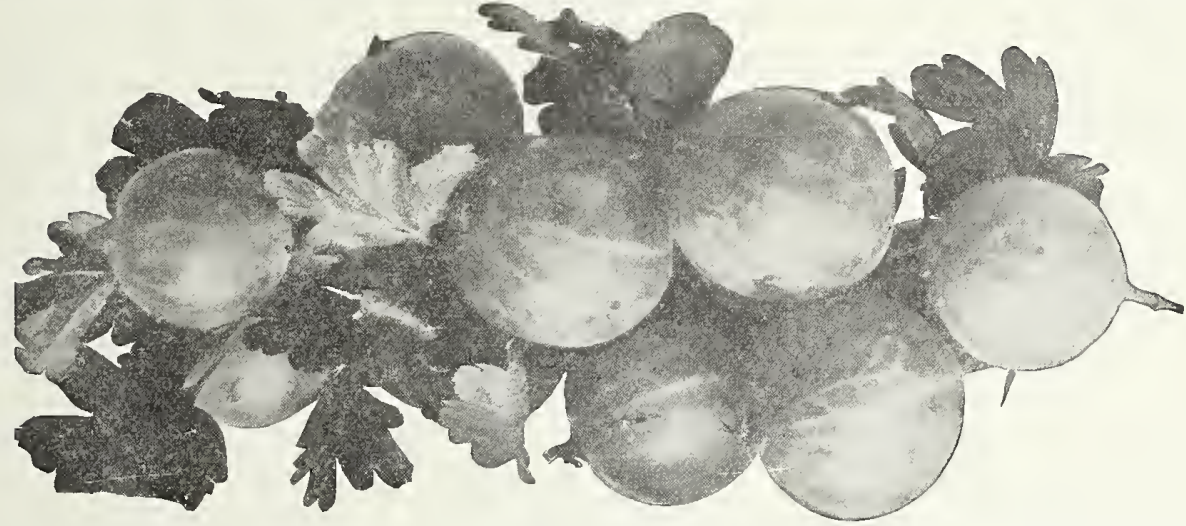

-Downing Gooseberry.

Downing-Fruit larger than the Houghton; roundish, light green with distinct veins, skin smooth, fiesh rather soft, juicy and very good; very valuable.

Industry-The best English Gooseberry yet introduced; of vigorous, upright growth, and greater cropper than any known variety, and less subject to mildew than any other English sorts; berries of the largest size, of most

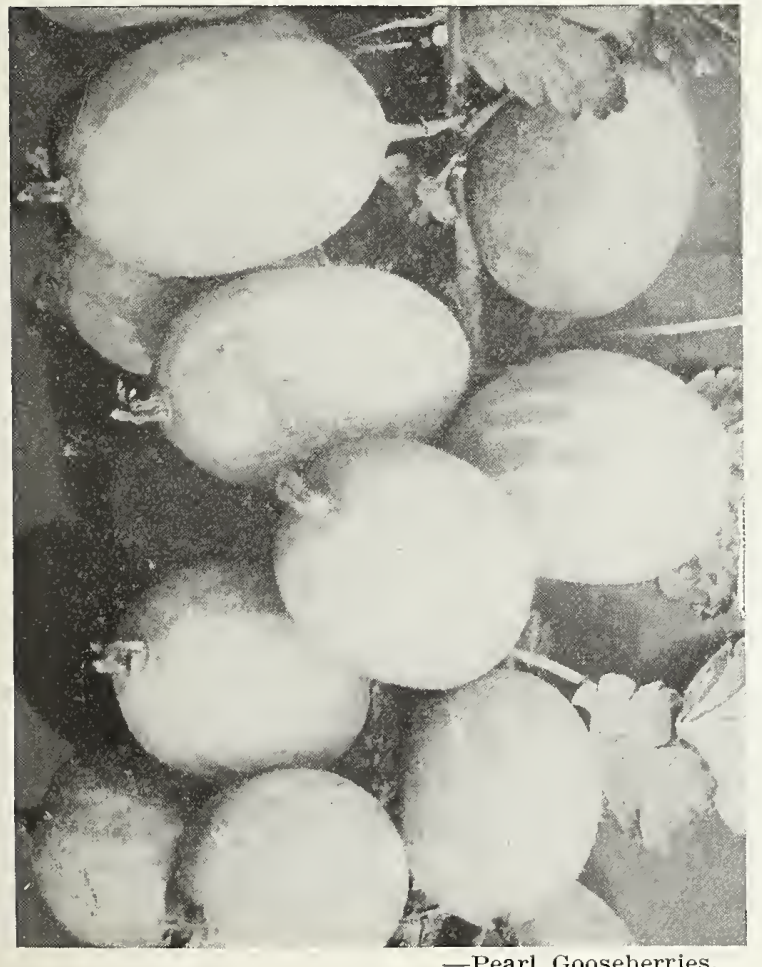

excellent flavor, both pleasant and rich; color when fully ripe, dark red.

Houghton-A medium sized American variety, which bears abundant and regular crops, and never mildews; fruit smooth, red, tender and very good; very valuable.

Pearl-Native American seedling; has a vigorous, healtly bush, free from mildew and very productive; berries larger than the Downing; rich and sweet.

Joselyn-A purely American variety rivaling the foreign sorts in size. A strong, thrifty grower, entirely free from mildew, very hardy and exceedingly productive. Berries large, smooth, a beautiful ruby red, fine flavor.

Smith's Improved-Large, oval, light green, with bloom; flesh moderately firm, sweet and good; vigorous grower.

\section{CURRANTS}

No garden for home use is complete without Currants. They flourish in almost every kind of soil, but to have the fruit in perfection, plant in rich, deep soil and give good annual pruning and cultivation. They ripen just at the close of the Raspberry season and continue in prime condition for several weeks.

Cherry-The largest of all the red cur rants. Berries sometimes more than half an inch in diameter; bunches short; plant very vigorous and productive when grown on good soils and well cultivated.

Crandall-A native black seedling of the Western wild currant; wonderfully productive, a strong, vigorous grower, usually producing a crop next year after 
planting; large size, easily picked; free from all attacks of insect enemies.

Fay's Prolific-Color deep red; great bearer; stems longer than Cherry and berries hold their size to the end of the stem better; quality first class, not quite so acid as the Cheriy; claimed to be the most prolific and best of ali red currants.

North Star - The average length of the bunches is four inches; the berries from a single bunch, thirty in number, placed side by side, touching, covered a line twelve inches in length. The fruit is superior, very sweet and rich in quality, firm, a good market berry, desirable as a dessert fruit in the natural state and unequaled for jelly.

Pomona-It is a beautiful, clear, bright, almost transparent red, has but few and small seeds, is much less acid than any of the common sorts; is easily picked hangs a long time after ripe, and is one of the best to hold up in shipping or on the market.

Red Dutch-An old, highly esteemed sort, hardy and reliable; fruit medium size, bright red and of best quality. It is well to plant some high priced, new kind, if you want a pet, but if you want currants plant Red Dutch.

White Grape-Very large, yellowish white, sweet or very mild acid; excellent quality and valuable for the table; the finest of the

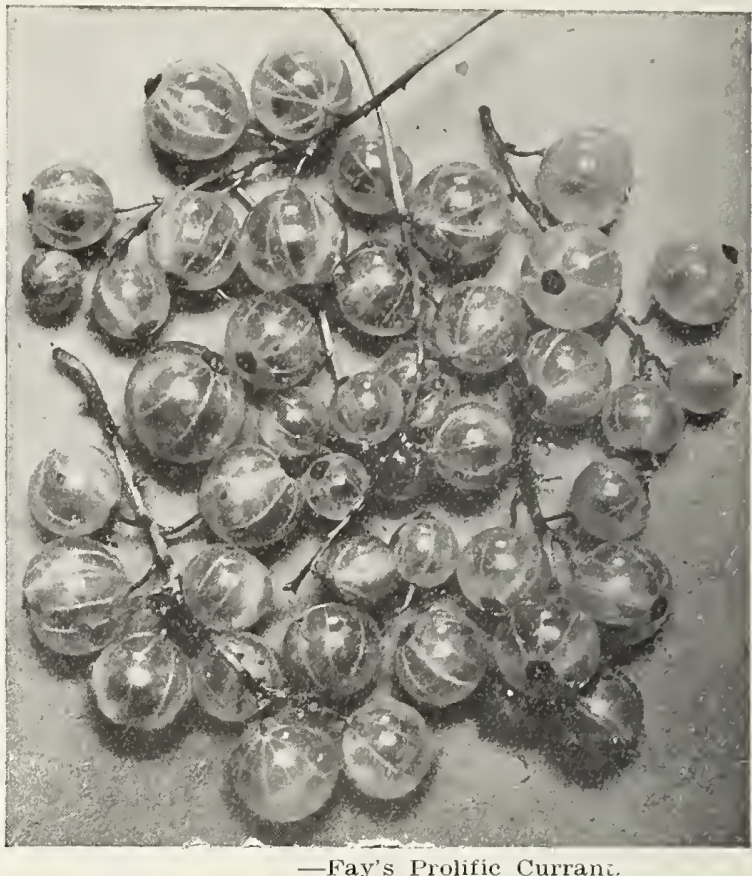

white sorts; has a low, spreading habit and dark gleen loliage; very productive.

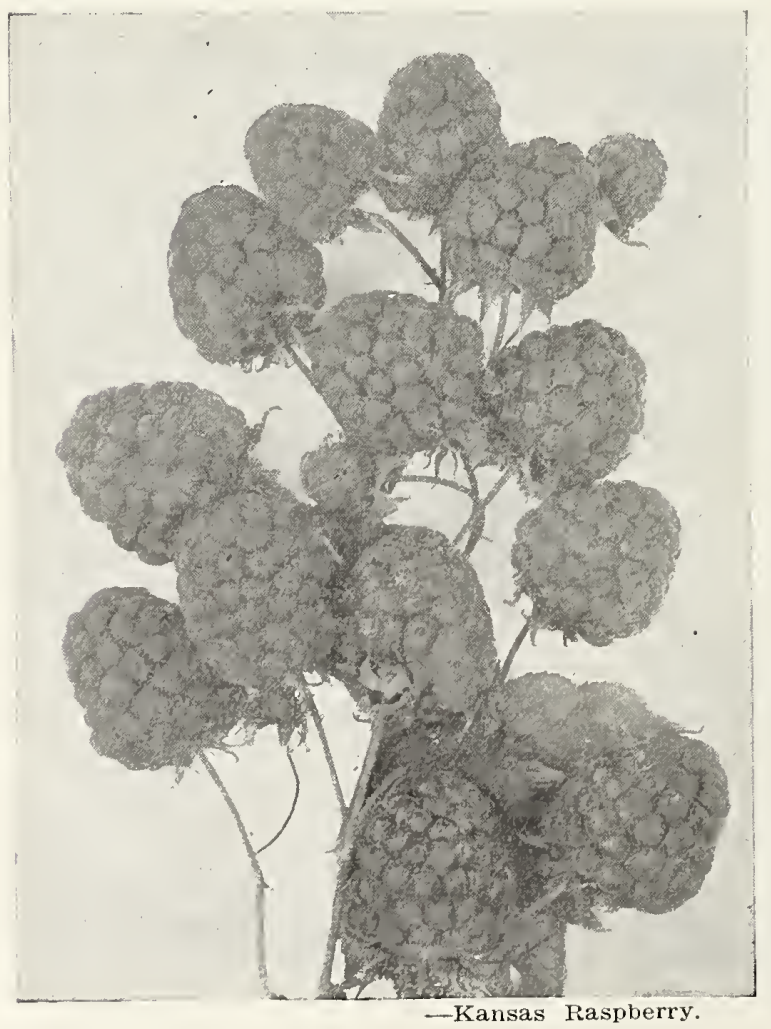

\section{RASPBERRIES}

One of the choicest of small fruits, coming into use as the strawberry season comes to an end. Nothing can be more refreshing than a dish of Raspberries. Should be planted four by six feet apart in a deep soil; one that will retain moisture well in a drouth. In training, allow only a few canes to grow: from each plant, cutting away all suckers, to throw the strength into the stalk for bearing. All old canes should be removed when the bearing season is over. Tender varieties should be protected during the winter in the Northern states.

Cardinal (Red)-This is the most remarkable plant in cane growth ever introduced. It is a strikingly beautiful bush to look at and this remarkable cane growth is extremely hardy. Its productiveness is all that could be desired; its berries are red, rich and highly flavored.

Cumberland (Black)-In hardiness and productiveness it is unexcelled by any other variety; berries are large and fine; quality very similar and fully equal to Gregg; fruit firm and will stand long shipments; bush healthy and vigorous, and well adapted for supporting their loads of large fruit; ripens midseason. 
Cuthbert (Red)-A remarkably strong, hardy variety; stands the Northern winters and Southern summers equal to any; berries large, conical, rich crimson, very handsome, firm, sweet and rich.

Gregg (Black)-One of the best of the black-cap family; a good grower; hardy and productive; fruit large, black and of fine quality; ripens late and evenly, so that its season is short; a very desirable variety, both for home consumption and for the market.

Kansas (Black)-Originated at Lawrence, Kansas; healthy, vigorous and not subject to leaf blights; produces strong, healthy tips; fruit large, as fine a berry as Gregg and equally as good a shipper; ripens early; very prolific.

Loudon (Red)-Canes strong and hardy; berries large size, good color and excellent quality; its vigor and hardiness, together with productiveness and fine quality, make it very desirable for either home use or a market fruit.

Strawberry-Raspberry (Red) - Introduced from Japan; a beautiful dwarf raspberry, seeming from its character to be a hybrid between the raspberry and strawberry; bush dies to the ground in the fall, makes a handsome low spreading plant, with dark green foliage: fruit is early, stands well out from the foliage; size and shape of a strawberry; color brilliant crimson.

\section{BLACKBERRIES}

No small fruit is better known than the Blackberry, ard none is mole useful and wholesome. I ney require the same kind of soil and treatment as

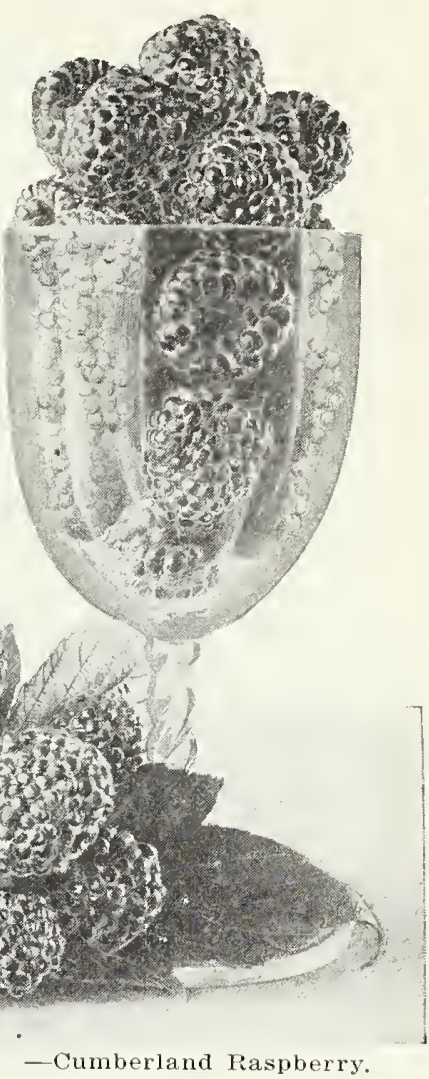

raspberries, except that they should be planted in rows 6 or 7 feet wide and 3 or 4 feet apart in the row. For self-sustaining bushes, clip off the points of the growing canes as soon as the plants are about 4 feet high, and repeat the operation several times, until they assume the

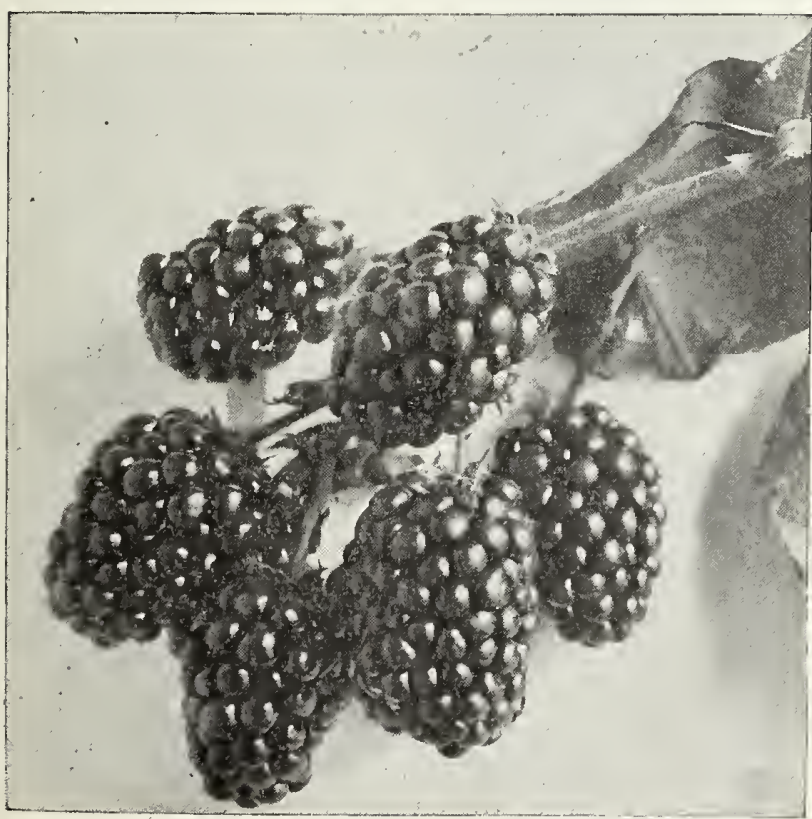

-Snyder Blackberry. form of a bush. Mulching is of great advantage to both raspberries and blackberries.

Ancient Briton - Upright grower; berly large. An old and reliable variety of IVales, which should be sufficient guarantee of its hardiness; fruit large, sweet, little to no core. Ripens about mid-season.

Blowers-Fruit large, and of good quality; plant a strong grower, hardy and productive; a promising new variety.

Early Harvest-The earliest of the blackberries; fruit medium, glossy black, good quality, firm and attractive in appearance; plant hardy and productive.

Eldorado - Vine is vigorous and hardy; berries large and borne in clusters and ripen well together; sweet, melting and juicy.

Erie-Cane strong; berry large, almost round, of rich quality, handsome and firm. Plant hardy, vigorous and productive, bending its canes with fruit. 
Kittatinny--Canes vigorous, hardy and productive; belries large and glossy black; flesh moderately firm, sweet, rich and excellent; the great fault of Kittatinny is the rust; wlien it escapes rust it is the best blackberry known.

Mercereau-Berries large, oval, very black; sweet and lich, vine hardy, vigorous and very productive.

Rathbun-Fresh, juicy and high flavored; soft throughout and no hard core; sweet and delicious; carries well to market; propagates from tips.

Snyder-Very hardy and productive; fruit of medium size, with no hard, sour core; half as many thorns as Kitlatinny, and they are straight and short; comparatively free from rust; a safe and profitable berry to plant; succeeds and yields well everywhere.

Taylor: or Taylor's Prolific-Strong, upright grower; berry large, late; very sweet and rich in flavor.

\section{DEWBERRIES}

The Dewberry is a trailing form of the blackberry. The fruit is larger and more luscious than the blackberry and is in demand in the market. The plants should be set two feet apart in the row and covered with straw during the winter. In the spring they should be muiched to keep the fruit off the ground.

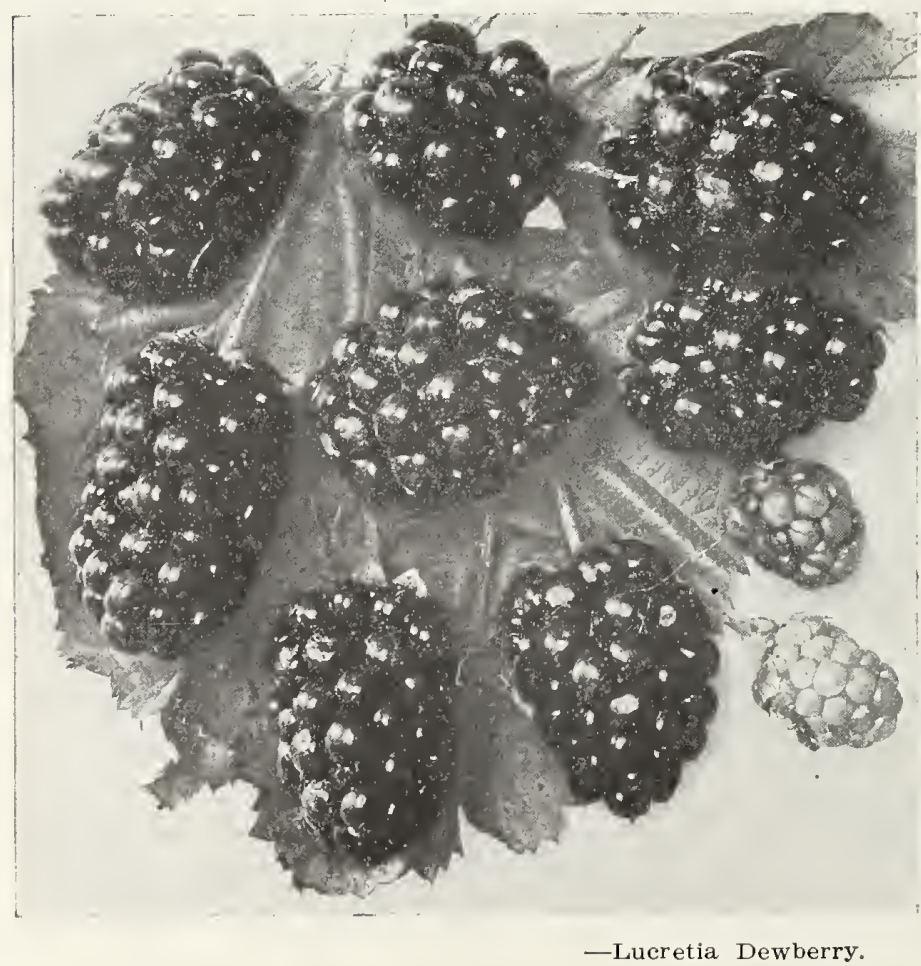

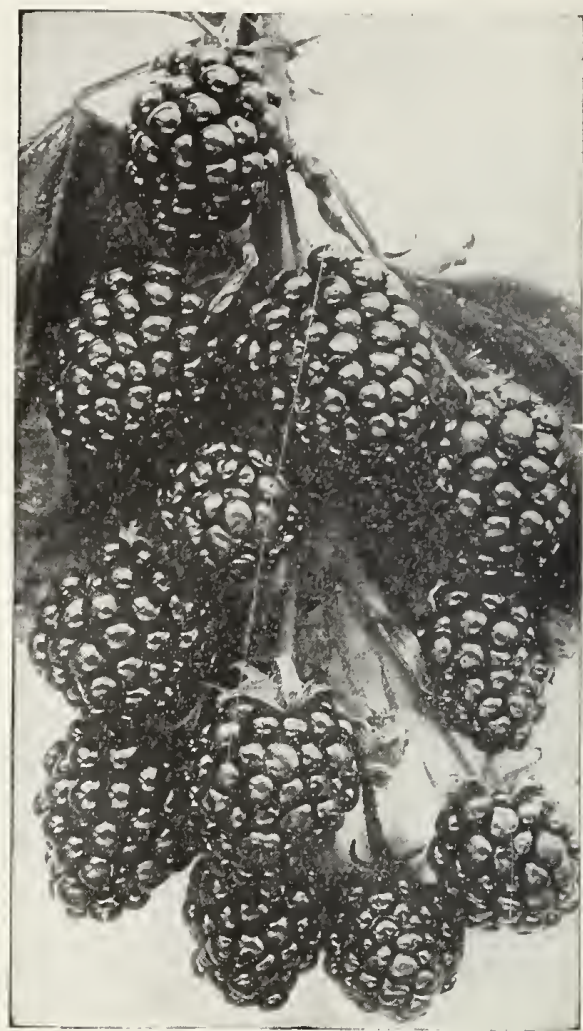

- Early Harvest Blackberry.

Austin-Large, glossy black and of excellent quality; the vines are vigorous and productive. Tinis variety is especially valuable one in the South.

Lucretia - Fruit very large, luscious and handsome; perfectly hardy, a strong grower and very productive; a superb and profitable market fruit.

\section{IMPROVED DWARF JUNEBERRY}

Grows three to five feet in height, branches out from the ground like currants. This plant begins to bear the second year after transplanting: and bears profusely. The berries are almost black, rich and sweet. Good for dessert or tor canning.

Berry plants from the Willis Nurseries are the kind that "make good." 


\section{STRAWBERRIES}

The Strawberry is one of the most beautiful as well as the most important of the small fruits and no fruit is in greater demand in its season. It can be successfully grown in any good garden soil. The ground should be carefully prepared and the plants set 12 to 18 inches apart in the row and the rows 3 feet apart. In the early winter the plants should be covered with straw and uncovered in the spring, the straw being leit between the rows as a mulch for the summer and to keep the fruit from contact with the ground. Staminate varieties, marked (S), will fertilize themselves. Pistillate varieties, marked $(\mathrm{P})$, must be planted with staminate in order to produce good crops.

Aroma (S) - A popular late variety, especially in the West and Middle West. A very firm, solid berry, and an excellent shipper; compared witl the Gandy it is about the same season, about the same size and about the same productiveness. The quality is very fine.

Bederwood (S) - Large, roundish, conical; bright scarlet, moderately firm, fair quality; plant vigorous and very productive. A valuable early sort for home use or near market.

Brandywine (S)-This variety comes in a good time between mid-season berries and late ones; thrives on a great variety of soils; a large, broad, heart-shaped berry, of medium red color, with bright yellow seeds and firm flesh, which is red to the heart; has a peculiarly rich, spicy flavor that charms all who taste it.

Bubach $(\mathrm{P})-\mathrm{A}$ wonderful berry in vigor of plant and yield of fruit even under careless culture; berries large, handsome and of fair quality; valuable for a nearby market. Midseason.

Captain Jack (S)-A most vigorous grower, healthy and productive. Berries large, handsome and solid.

Charles Downing (S)-Large, conical, crimson; flesh firm, of fine flavor and good quality; plant healthy, vigorous and productive. A good fertilizer for all pistillate varieties.

Crescent (P)-Medium, conical, bright scarlet,

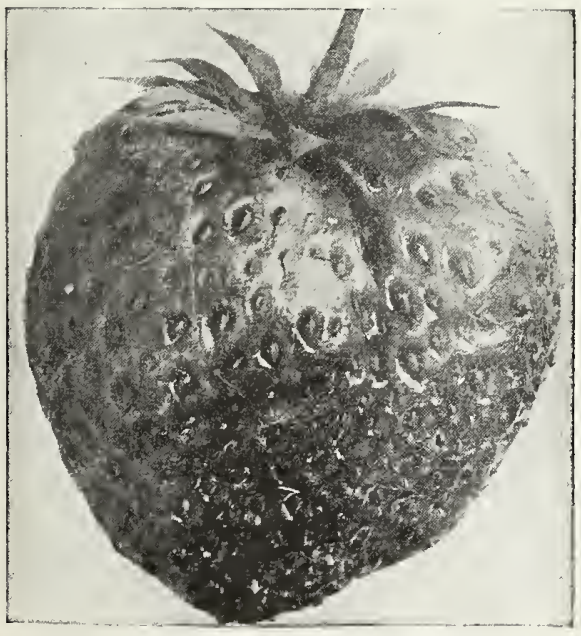

- Senator Dunlap Strawberry.

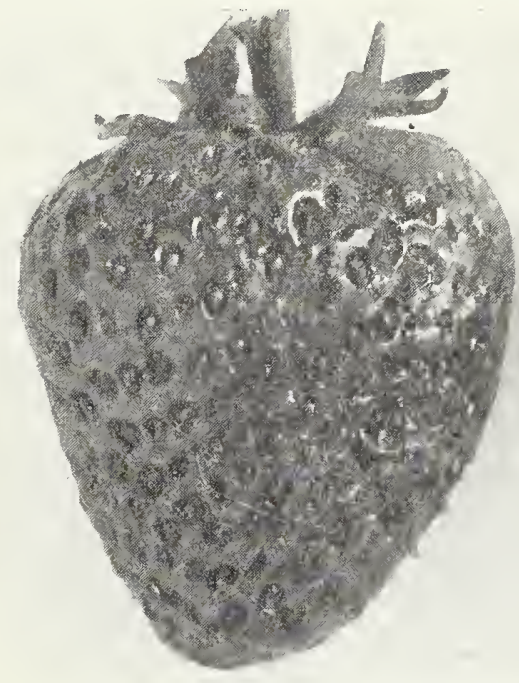

-Arema Strawberry.

uniform in size, a beautiful berry; has been shipped 200 miles without changing color; very productive; a prolific plant maker; at home on all soils.

Cumberland Triumph (S)-Berries large, of fine form and flavor; plant very vigorous and productive.

Excelsior (S)-An early berry, planted extensively; foliage tall and dark green; fruit almost round and very dark red; a good plant maker and if rows are allowed to become too thick, the last pickings will be small. A few object to it on account of its tart flavor, but we believe you will make no mistake in planting it for an early berry. It is productive. A nice looking berry and a good shipner.

Gandy (S) - A reliable late variety; berries bright crimson, very uniform in size and shape, large, firm; plant vigorous and healthy.

Greenville (P) - Resembles Bubach, but is firmer and a better shipper; uniform in size, regular outline, excellent quality. Plant a strong grower, free from rust and one of the most productive.

Jessie (S)-A stout luxuriant grower; foliage light green, large and clean; the berry is very large, continuing large to the last picking; is of a beautiful color, firm quality, good 
form, having been shipped 600 miles in good condition.

Parker Earle-Very productive, flower perfect, protected from late frosts by abundance of leaves; trusses strong, long and large; berries regular, conical with short neck; glossy, scarlet crimson, firm; no hollow core, seeds golden. It shows well several days after picking; presents an attractive appearance in the crate. Season early to medium.

Robinson (S)-Fruit large and perfect; firm and a good shipper; plant a great grower and fertilizer; prolific.

Sample (P) - A very productive berry, medium to late in ripening; in fact it should be classed as late as more of its berries ripen in that season; a good plant maker of strong, thrifty plants; fruit above the medium in size, firm, good color, and holds up well for a long season.

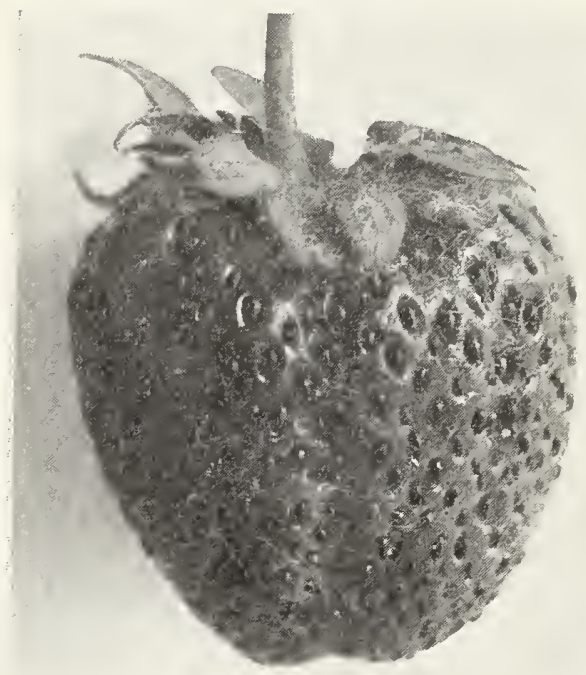

-Parker Earle Strawberry.

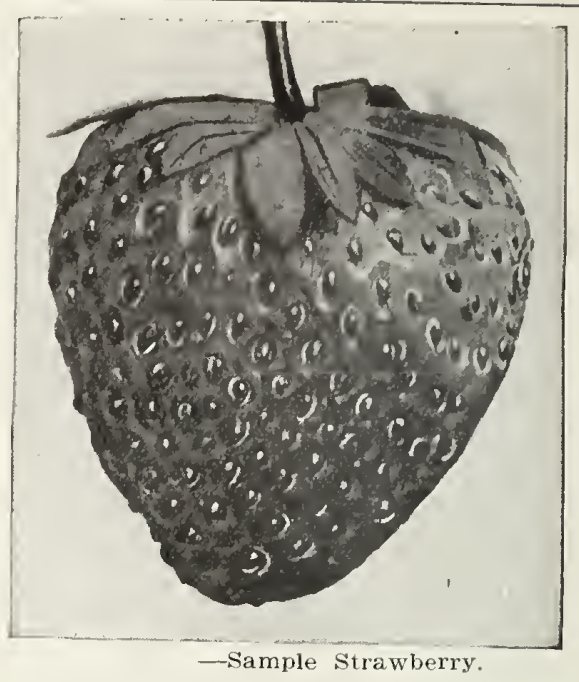

Senator Dunlap (S)-A variety that seems to give general satisfaction all over the country. A perfect bloomer and prolific plant maker of medium size plants; medium in fruiting season; very productive; berries medium to large in size, and very dark red in color when fully ripe; firm and have a peculiarity of remaining on the vines longer after ripening than most varieties without becoming soft; seems to do well on all kinds of soil and in all sections.

Sharpless (S)-Very large, generally oblong, narrowing to the apex, irregular, often flattened; clear bright red, with a smooth, shining surface; firm, sweet, with a delicious aroma; vigorous, hardy and very productive when raised in the hills, with runners cut off.

Warfield (S)-Possesses beauty, firmness, earliness, good flavor, productiveness; is not immensely large, but quite satisfactory.

\section{PLANT STRAWBERRIES IN THE SPRING.}

\section{ASPARAGUS}

This delicious and healthy vegetable should be found in every garden. Nothing can be more easily grown and no plant gives such healthful food for so little outlay. To make a good asparagus bed prepare a piece of fine loamy soil, to which has been added a liberal dressing of good manure. Set the plants in rows 18 to 20 inches apart, with plants 10 to 12 inches apart in the row. Make a small mound of the soil, over which the roots should be evenly spread, so that the crown, when covered, should be three inches below the surface of the ground. If planted in the fall, the whole should be covered before winter sets in with two or three inches of coarse stable manure, which may be lightly forked in between the rows as soon as the ground is softened in the spring.

Conover's Colossal-A mammoth variety of vigorous growth, sending up from 15 to 20 sprouts, from one to two inches in diameter, each year; color is a deep green; the crown is close.
Giant Argenteuil-Originally introduced from France; comes up early in the spring. This variety is more productive and the stalks are larger than in the other sorts. A very desirable market sort.

\section{RHUBARB OR PIE PLANT}

This deserves to be ranked among the best vegetables in the garden. It affords the earliest material for pies and tarts, continues long in use, and is valuable for canning. Make the border very rich and deep for this plant.

Linnaeus-Large, early tender and fine. The Victoria-Large, early and a valuable market very best of all. 


\section{ORNAMENTAL DEPARTMENT}

As the country grows in age and wealth, the realization of the need for beautifying the grounds that surround the home become more general. We are beginning to see that well-kept and attractive grounds add very much not only to our own satisfaction, but to the actual value of the place. Large grounds may be planted according to some pre-arranged plan with large trees and shrubs. If the grounds are smaller, the smaller shrubs, and especially vines and roses, can be used to good advantage. The value of vacantlots is often largely increased by beautifying them with a wise planting of trees and shrubs.

HOW TO PLANT-A fine, well-cut lawn is one of the handsomest features of any place, so do not make the mistake of planting at random all over the grounds. Trees should be planted along a drive or in groups or lines according to a definite and well-arranged plan. The small shrubs and roses should be planted in beds where they can be well cultivated and pruned, so as to produce the finest results. An unsightly object may often be conceaied by careful planting of trees, shrubs or vines.

PREPARATION FOR PLANTING-Dig the hole somewhat larger than is necessary to hold the tree or plant, and then fill in with good rich earth. Cut off all the bruised or broken roots back to the sound wood, cut back the top and side branches to correspond with the roots.

WHAT TO PLANT-Plant only the best. Poor stock is high at any price, good stock is worth a good price. To meet the increasing demand in this line, we have added largely to our stock of ornamental trees, shrubs, vines and roses in the last few years. No pains have been spared to produce the best specimens, and we offer now a good assortment of strictly choice stock of such varieties as are suitable for this section of the country.

\section{UPRIGHT DECIDUOUS TREES}

Ash, White-A rapld-growing native tree of fine symmetrical outline; a valuable street or park tree, and should be extensively planted for timber, as the demand for this timber is very great for the manufacture of implements, railway cars and furniture.

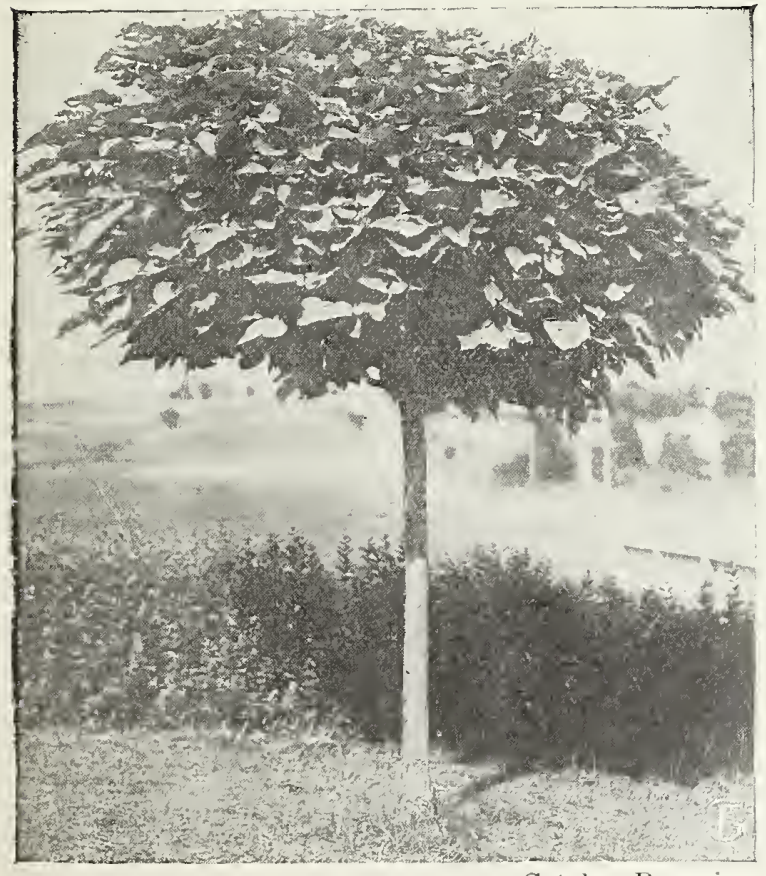

—Catalpa Bungei.
Birch, European White-A well-known tree, with graceful, airy foliage and silvery white bark; very desirable for the lawn, either as a single specimen or in contrast with other trees in a group.

Box Elder, Ash-Leafed Mapie-A fine, rapidgrowing varlety, with handsome, light green foliage and spreading head; very hardy, excellent for avenues.

Catalpa, Bungei-A Dwarf Catalpa, close, compact shrub, absolutely healthy and hardy; its branches are numerous and short, the broad leaves lay as shingles on a roof, making a dense shade, and when top-grafted on a standard, makes an umbrella-shaped top tree, equal to the famous Chinese Umbrella tree of the South.

Catalpa, Speciosa-A variety originating in the West, more upright and symmetrical in its growth than the common Catalpa, and blossoms two or three weeks earlier. Very valuable for timber, fence posts, railroad ties, etc., possessing wonderful durability. A very ornamental and valuable tree.

Crab, Bechtel's Double Flowering-One of the most beautiful of the many fine varieties of flewering Crab Apples. Tree of medium size, covered in early spring with large, beautiful, double, fragrant flowers of a delicate pink color. From a distance the flowers have the appearance of roses. A great acquisition. Blooms when quite young.

Dogwood-An American species of fine form, growing from 16 to 25 feet high; 
the flower's are produced in the spring before the leaves appear, are from three to three and one-half inches in diameter, white, very showy, the foliage in autumn is of a deep red color, rendering the tree one of the most beautiful objects at that season.

Elm, American White-The noble drooping, spreading tree of our own woods; one of the grandest of park or street trees.

Horse Chestnut, Common or White Flowering -A very beautiful, well-known tree, with round, dense head, dark green foliage, and an abundance of showy flowers in early spring. As a single lawn tree or for street it has no superior.

Linden, American Basswood-A fine native tree, grows rapidly and attains a large size; leaves a dark green above, light green underneath; flowers are creamy white and fragrant.

Linden, European-A very fine pyramidal tree of large size, with large leaves and fragrant flowers, the leaves change in the fall to beautiful tones of yellow and brown.

Locust, Black or Yellow-A native tree of large size, rapid growth, and valuable for shade as well as quite ornamental. The flowers are disposed in long, pendulous racemes, white or yellowish, very fragrant and appear in June.

Locust, Honey-A rapid-growing tree; delicate foliage, of a beautiful, fresh, lively green, and strong thorns; makes an exceedingly handsome, impenetrable and valuable hedge.

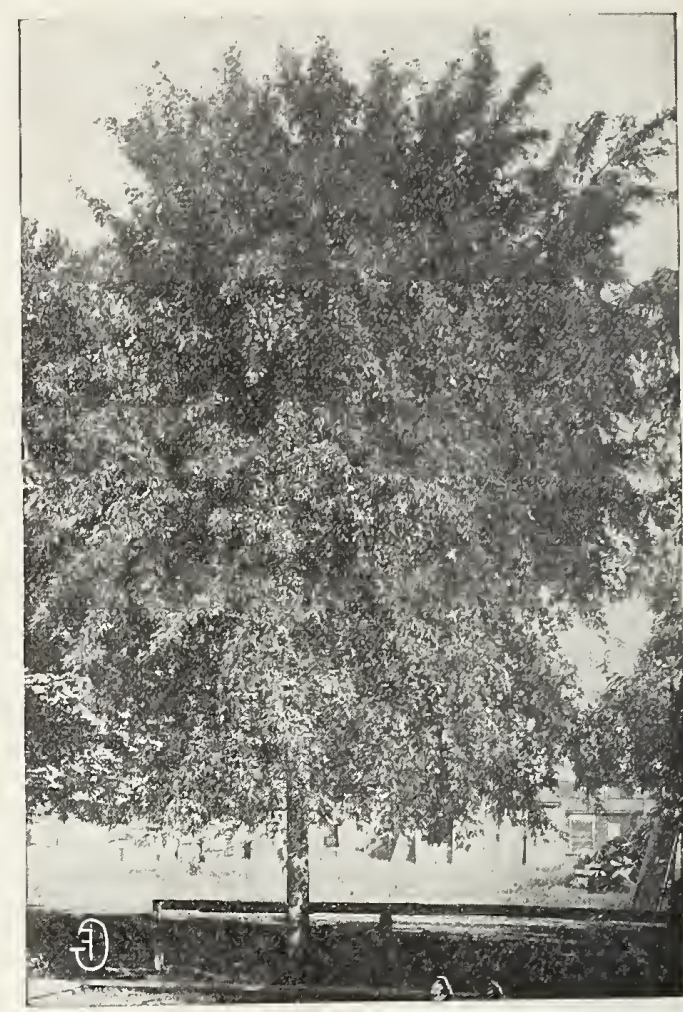

Silver-Leafed Maple.

Maple, Norway-A foreign variety, with large, broad leaves of a deep rich green; probably the best Maple in cultivation.

Maple, Silver-Leaved-Of rapid growth; of great value where a rapid-growing iree is desired; very hardy and easily transplanted; a favorite street or park tree.

Maple, Sugar or Rock-A very popular American tree, and for its stately form and fine foliage, justly ranked among the very best, both for lawn and avenue.

Maple, Wier's Cut-Leaved-A Silver Maple, with remarkable and beautiful dissected foliage. Of rapid growth; shoots slender and drooping, giving it a very graceful appearance; should be in every collection.

Mountain Ash, European-A very beautiful tree of medium size, with an erect stem, smooth bark and round head; covered during the fall and winter with bright scarlet berries; universally admired.

Mountain Ash, Oak-Leaved-A handsome tree of erect habit and rich green foliage, deeply lobed; very hardy and desirable. 
Olive, Russian-An ornamental tree of special value; attains a height of thirty feet or more; bark and leaves light green when young, bark becoming darker as the tree grows older, and leaves more silvery white; blooms profusely in June in smali racemes three inches iong, and their fragrance is decidedly sweet and spicy; an excellent lawn tree.

Persimmons; American-A small native tree; foliage dark green and very dense; fruit over an inch in diameter, pale orange yellow; very desirable.

Plum, Purple-Leaved-Tree of medium size, wood and leaves a dark purple; fruit is also purple until ripened when it turns red; one of the most conspicuous ornamerital trees.

Poplar, Carolina-Of good form and vigorous growth; leaves large and glossy; desirable where a very large tree is desired.

Poplar, Lombardy-Attains a hejght of 100 to 150 feet; well known for its erect, rapid growth and tall spiry form; an indispensible tree for landscape gardening.

Poplar, Norway - Similar to Carolina Poplar in growth and appearance, but is claimed to be a more rapid grower. Will thrive in almost any soil or location; valuable for street and park planting, especially where quick shade is required.

Poplar, Silver-Leaved-A tree of very rapid growth and wide spreading habit; leaves large, dark, glossy green above and white underneath; prefer's a moist soil, but grows anywhere.

Red Bud, or Judas Tree-A very ornamental, small tree, native of the Western states, which, in the early spring before the leaves appear, is covered with delicate pink flowers. "Nothing can be more Deautiful in April or May than a large, round-headed Red Bud, cov-

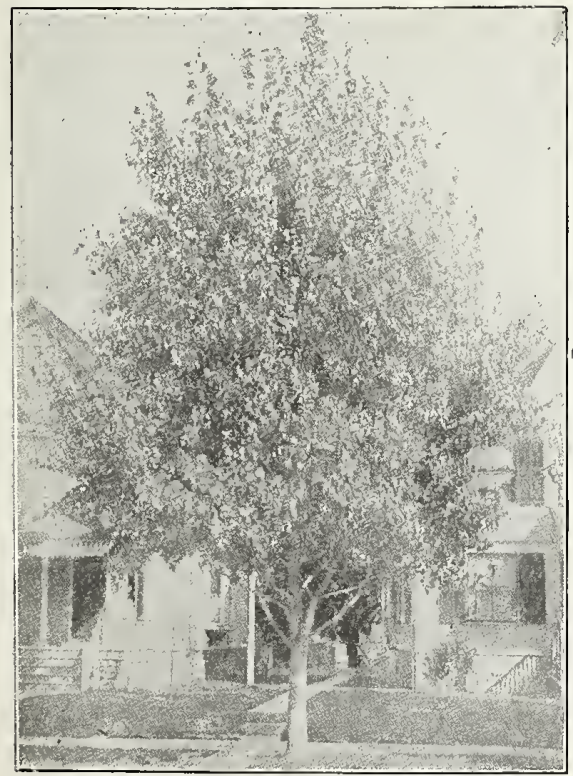

-Carolina Poplar.

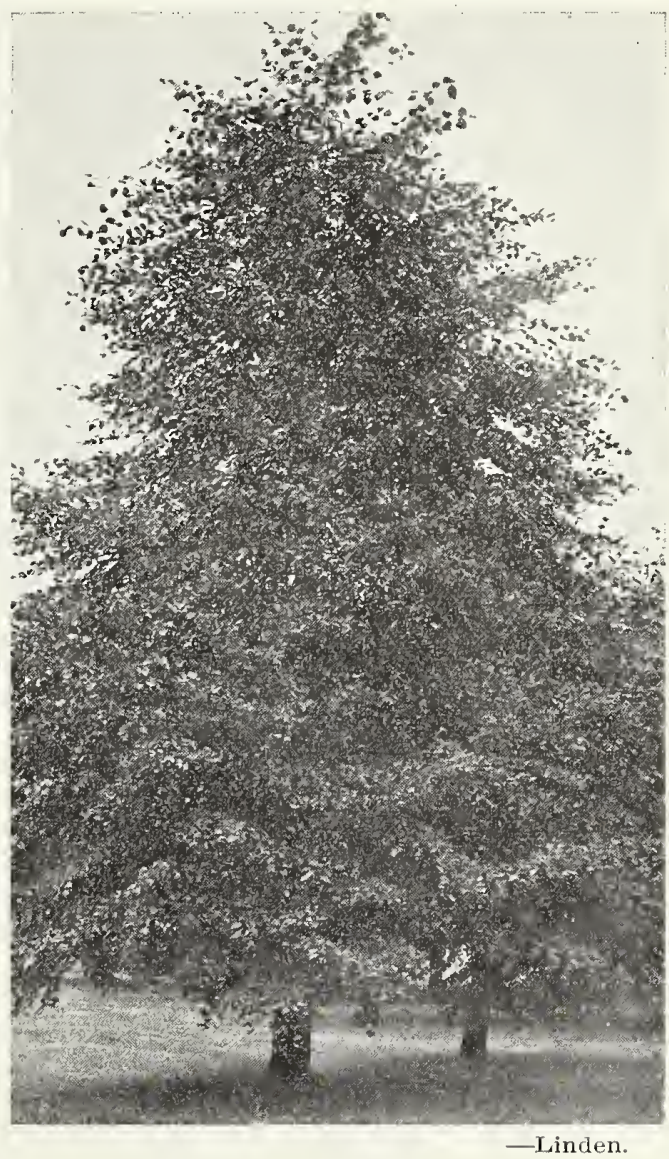

ered with its beautiful flowers, before the bursting of a single leaf."

Sycamore, American Plane-A large, rapid growing, well-known tree that is well adapted for streets in cities where the gas and smoke are injurious to foliage.

Tulip Tree-A native tree of the Magnolia order, remarkable for its symmetry, its rich, glossy foliage, regularly distributed branches and large tulip-like flowers; difficult to transplant unless of small size.

Thorn, Paul's Double Scarlet-A tree with a fine habit; with rich, luxuriant foliage; flowers large and deep crimson; very double.

\section{Weeping Deciduous Trees}

Birch, Cut-Leaved Weeping-An elegant, erect tree, with slender, drooping branches and fine cut leaves. A magnificent variety and worthy of a place on every lawn. We know of no more beautiful tree than the cut-leaved weeping Birch.

Elm, Camperdown Weeping-Its vigorous, irregular branches, which have a uniform weeping habit, overlap so regularly that a 
compact, roof-like head is formed; the finest Weeping Elm.

Mountain Ash, Weeping-A beautiful tree, with straggling, weeping branches; makes a fine tree for the lawn.

Mulberry, Tea's Weeping-A graceful and beautiful, hardy tree, forming a perfect umbrella-shaped head, with long, slender, willowy branches, drooping to the ground and gracefully swaying in the wind. Foliage small, lobed, and of a delightful, fresh, glossy green.

Willow, Kilmarnock Weeping-An exceedingly graceful tree, with rather small, glossy leaves; one of the finest of this class of trees; very hardy.

Willow, Wisconsin Weeping-Of drooping habit and beautiful form; the most hardy of all our weeping willows.

\section{Evergreens}

Arbor Vitae, American-A fine native tree of medium size; commonly known as White Cedar; one of the best of the Evergreens for screens and more used than any other variety for ornamental hedges.

Arbor Vitae, Pyramidalis-The most beautiful of all Arbor Vitaes, having dark green, compact foliage and remarkably erect form; perfectly hardy.

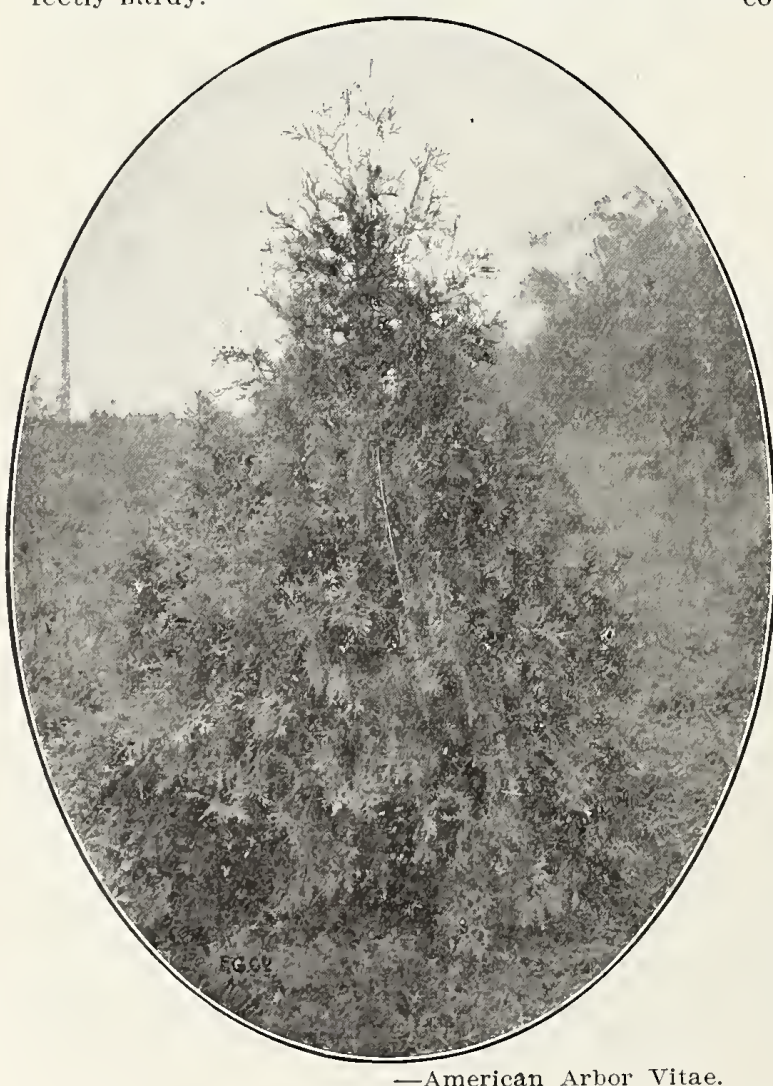

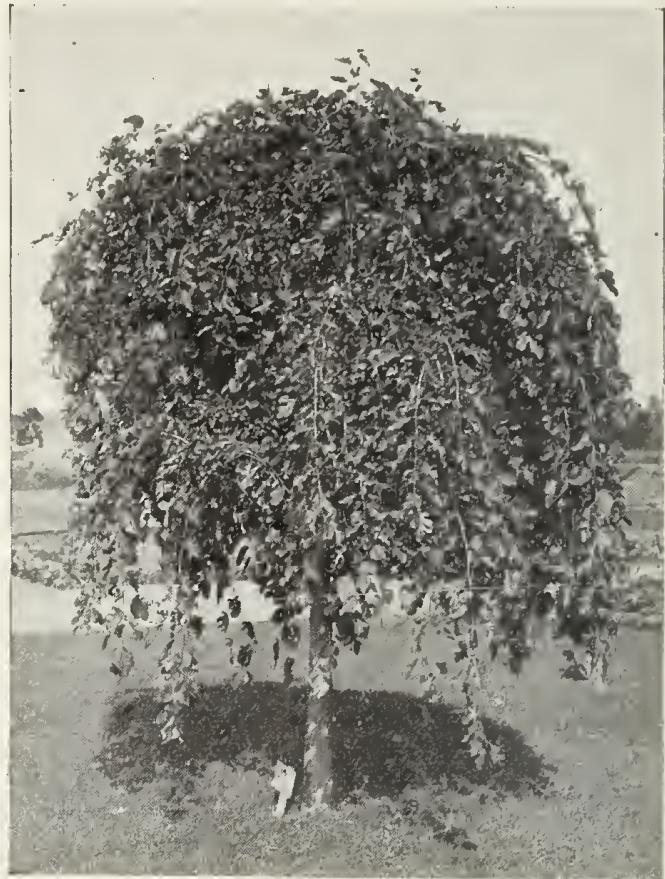

—Weeping Mulberry.

Arbor Vitae, Siberian-Grows slower and more compact than the American, of which it is a variety; foliage thicker, more luxuriant and keeps its color well in winter; perfectly hardy; one of the most desirable and useful evergreen trees in this climate.

Juniper, Irish-A distinct and beautiful variety of erect, dense conical outline, resembling a pillar of green; very desirable

Pine, Austrian or Black - A native of the mountains of Syria; a rapid growing. species with long, stifi, dark green leaves; very hardy.

Pine, Scotch-A native of Eritish Islands; very rapid in its growth. A clark, tall evergreen, with bluish foliage and rugged shoots; hardy and grows well even on the poorest soils.

Pine, White-The most ornamental of all our native pines; foliage iight, dclicate or silvery green; flourishes in tho foorest soils

Red Cedar-A well known American Evergreen with deep green foliage; makes a fine ornamental hedge plant. One of the hardiest and most reliable. About the ouly evergreen we know of that is indigenous to Kansas.

Spruce, Norway-A lofty, elegant tree, of perfeci pyramidal habit, remarkably elegant and rich, and as it acquires age has fine, graceful pendulous branches; it is exceedingly picturesque and beautiful; very popular and deservedly so, and should be largely planted. 


\section{Ornamental Shrubs}

\section{ALTHEA, or Rose of Sharon}

A large and beautiful shrub; flowels large,do uble and of many brillíant colors; especially valuable because of their flowering in August and September when nearly all other shrubs are out of bloom; entírely hardy and easy of cultivation.

Ardens-Víolet rose; very large and double.

Boule de Feu-Bright red; very double; blooms late.

Duchess de Brabant-Red; very large and double.

Jeanne d'Arc-One of the best; pure white; very double.

Lady Stanley-Delicate pink; vely double.

Variegated Leaved-Leaves variegated with a light yellow; very ornamental.

Almond-Double pink floweríng. A beautíful shrub, with small, double, rosy blossoms, closely set upon the twigs betore the leaves appear.

Almona-Double white flowering, Similar to the pink, except is a pure white; an abundant bloomer.

Calycanthus - Sweet-scented shrub; an interesting shrub, having a rare and peculiar fragrance of wood and flowers; its blossoms are abundant, and of peculiar chocolate color.

Deutzia-Double Llowered, a hardy shrub with luxuriant foliage and beautiful flowers; produced late in June on long racemes. They are white tinged with pink and very double

Forsythia-Leaves dark green; flowers brigh $\downarrow$ yellow, opening very early in the spring. A fine, hardy shrub.

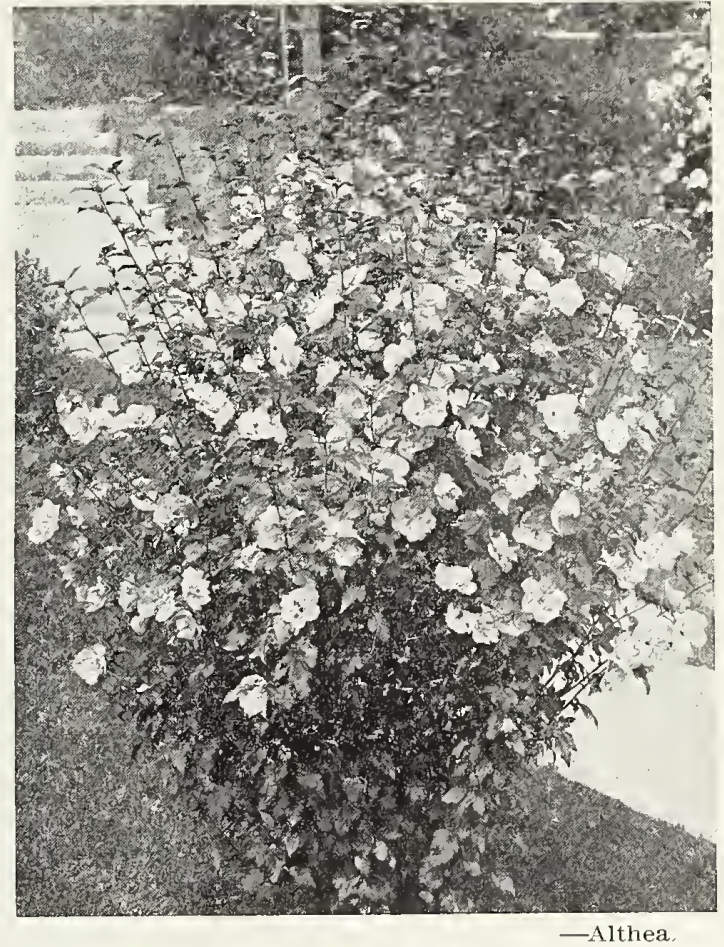

Honeysuckle, Tartarian-A well known shrub flowers bright pínk, which appear in May.

White Tartarian-Similar to the pink, but has creamy white flowers.

Hydrangea, Hardy-A fine large shrub, bearing showy panicles of white flowers in the greatest profusion; quite hardy and is altogether a most admirable shrub for planting singly or on the lawn in masses. Blooms in August and September.

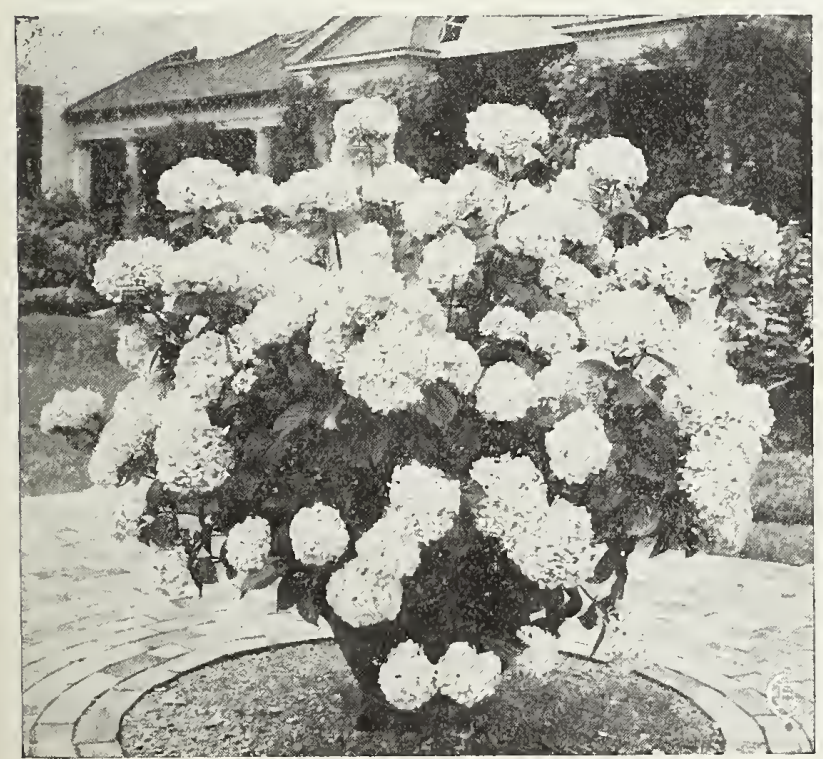

-Hydrangea.
Japan Quince-Produces an abundance of bright crimson flowers early ín the spring before the leaves appear; folíage bríght green and glossy, retaining its color through the summer. Is hardy and thorny and makes a good hedge plant.

Lilac, Common Purple-One of the hardiest, best shrubs; very well known and popular.

Lilac, Common White-Similar to the purple, but flowers are pure white

Plum, Double Flowering-Flowers double, delicate pink, closely set along slender branches and appearing early in the spring.

Privet, California-Hardy, rapíd-growing shrub, with deep, glossy green leaves; very valuable for hedges.

Purple Fringe, or Smoke Tree-A conspicuous, small tree, spreading liabit, covered in mid-summer with a profusíon of dusky, frínge-líke flowers. 
Snow Ball-A well-known favorite shrub, of large size, with globular cluster's of white flower's in May.

Spirea, Anthony Waterer-An improved dwarf Spirea, with dark red flowers; a very desirable variety.

Billardi-Flowers rose colored, are produced in large panicles nearly all summer.

Van Houttei-The most charming and beautiful of the Spireas; bush vigorous and hardy; foliage a rich green; flowers are pure white, borne in clusters along the branches; an indispensible shrub.

Syringa, or Mock Orange-The Syringa is a large shrub growing from 6 to 10 feet high; vigorous habit, hardy; with large, handsome foliage and beautiful white flowers; fragrant; blooms very freely.

Weigelia Rosea-A beautiful shrub with deep rose-colored flowers.

White Fringe-One of the best shrubs or small trees; superb foliage and delicate fringe-like white flowers.

\section{Hardy Vines}

Ampelopsis Quinquefolia, American Ivy, or Virginıa Creeper-A native vine of rapid growth, with large, luxuriant foliage, which in the autumn assumes the most gorgeous and magnificent coloring; the blossoms are inconspicuous; succeeded by handsome dark blue berries. The vine is best calculated to take the place in this country of the celebrated English Ivy, and really in summer it will be found not inferior to it.

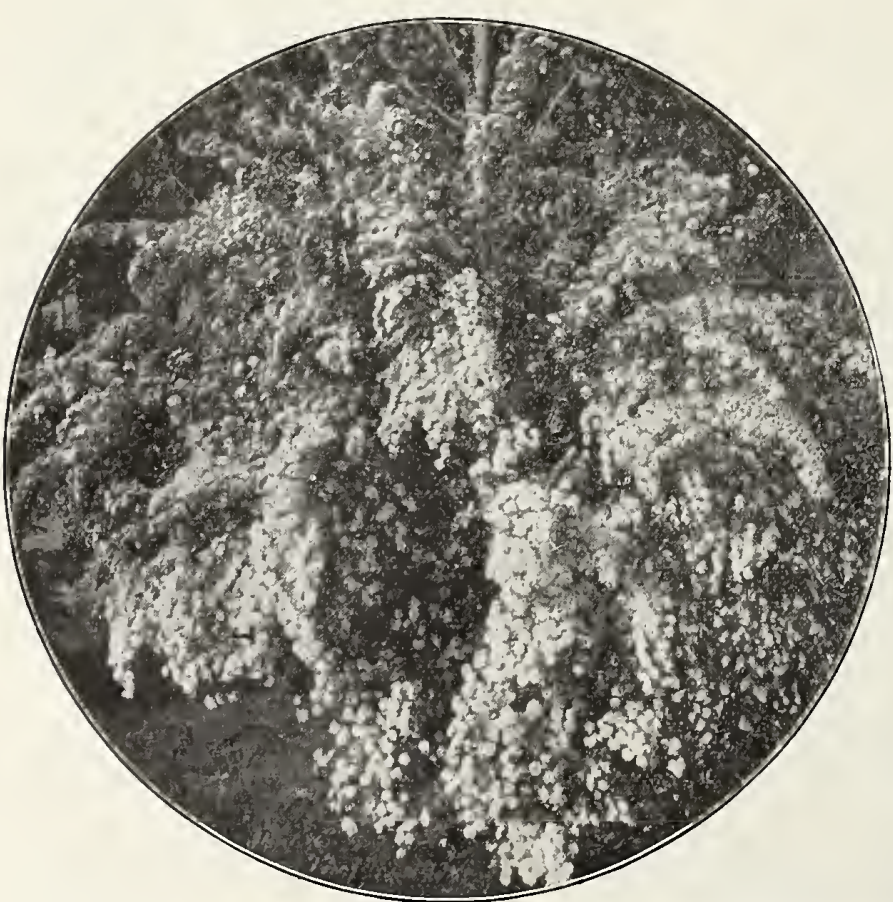

-Spirea Van Houttei.

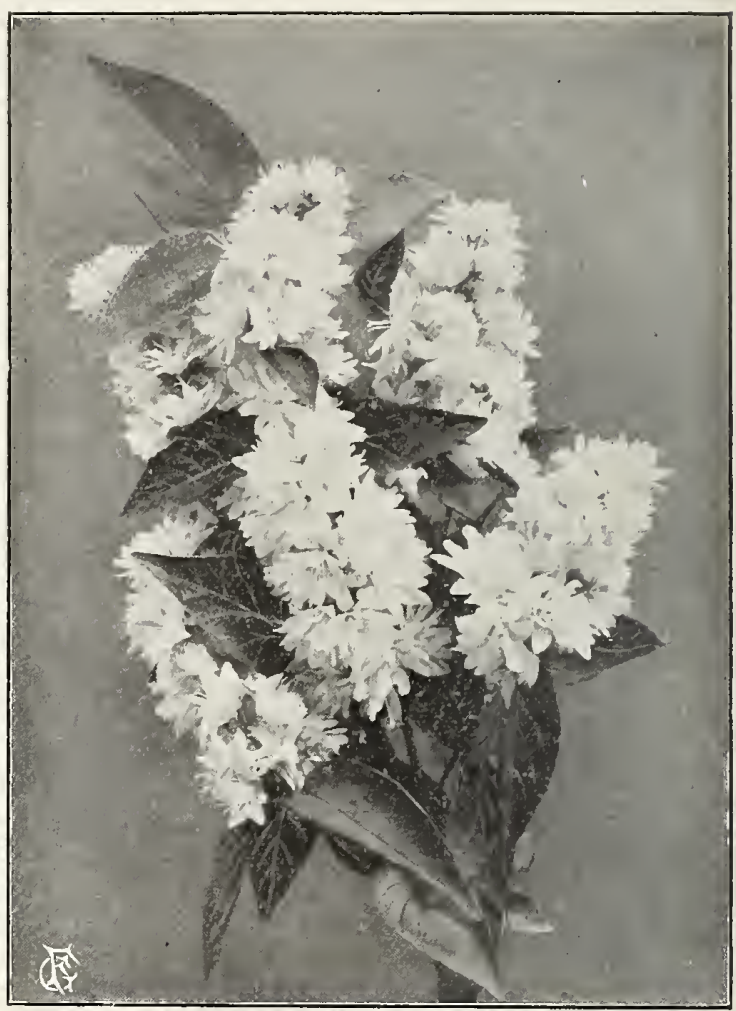

-Deutzia.

Ampelopsis Veitchii, Boston Ivy-Foliage is smaller than those of the American and more dense, forming a sheet of green. The plant is a little tender while young, and should be protected the first winter. When once established grows rapidly and clings to a wall or fence with the tenacity of ivy. The foliage, while handsome in summer, changes to a crimson scarlet in autumn; very beautiful for coverng walls, stumps of trees, rockeries, etc., and for ornamentation of brick and stone structures it has no equal.

Bignonia, Trumpet Creeper-A splendid climber, vigorous and hardy, with clusters of large, trumpei shaped flowers in August.

\section{CLEMATIS, Virgin's Bower}

The different varieties and species of Clematis now in cultivation are of the highest beauty and utility. They vary greatly in their foliage and flowers, and are adapted to various uses. The large-flowered varieties are extremely showy. These plants when trained on trel- 
lises and over porches, pillars and rock work, produce great masses of bloom, which make a grand appearance, especially when contrasting colors are in proximity.

Henryil-Fine, large, pure white; one of the best long bloomers.

Jackmanni-A very profuse blooming variety, with flowers from four to six inches in diameter, of an intense violet purple color, borne successively in continuous masses on the summer shoots.

Madam Edouard Andre-The nearest approach to a bright red yet produced. The plant is a strong, vigorous grower, being a hybrid of the popular Jack manni variety, which it resembles in freedom of bloom, strong, vigorous growth, shape and size of flowers.

Paniculata-Most beautiful and popular of the small flowering sorts. A vine of very rapid growth, quickly covering trellíses and arbors with handsome, clean, glossy green foliage. The flowers are of medium size, pure white, borne in immense sheets, and of a most delicious and penetrating fragrance. The flowers appear in September, at a season when very few other vines are in bluom.

Dutchman's Pipe-A native species of climbing habit and rapid growth; light green foliage and pipe shaped yellowish brown flowers.

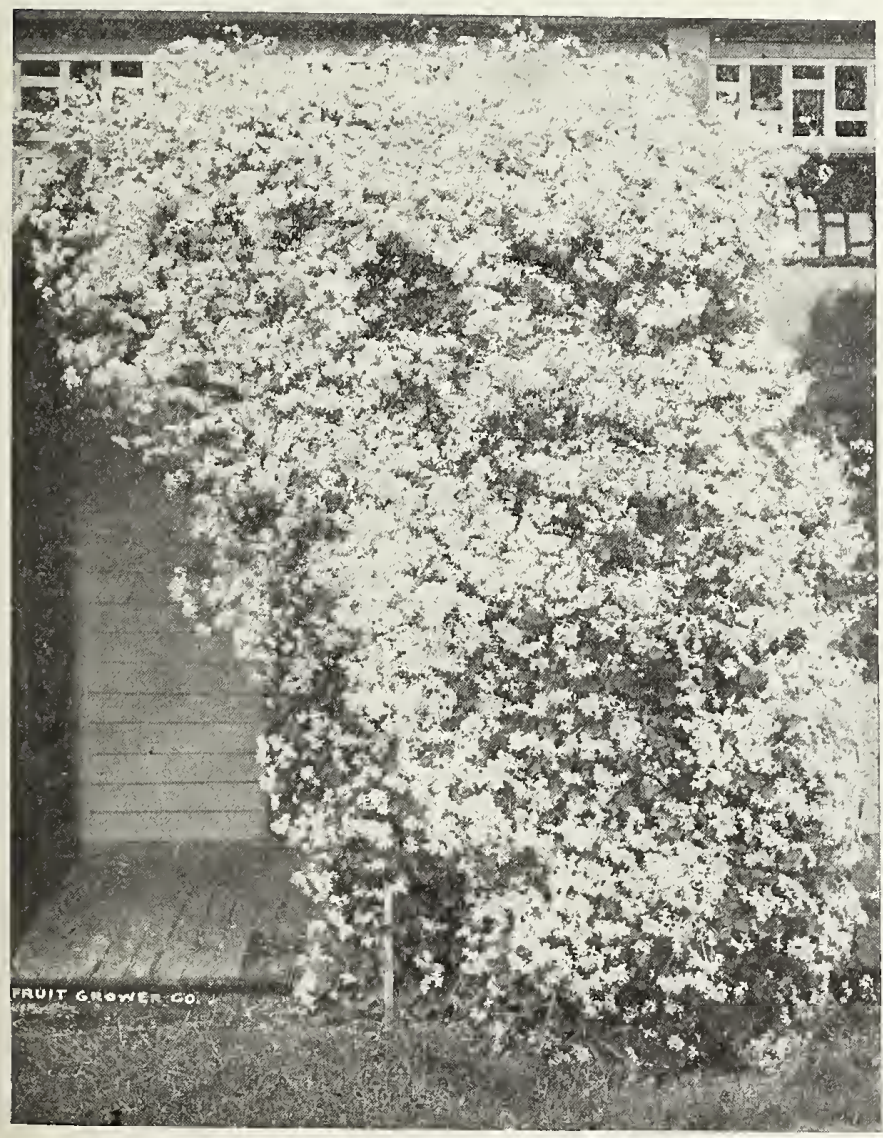

-Clematis Paniculata.

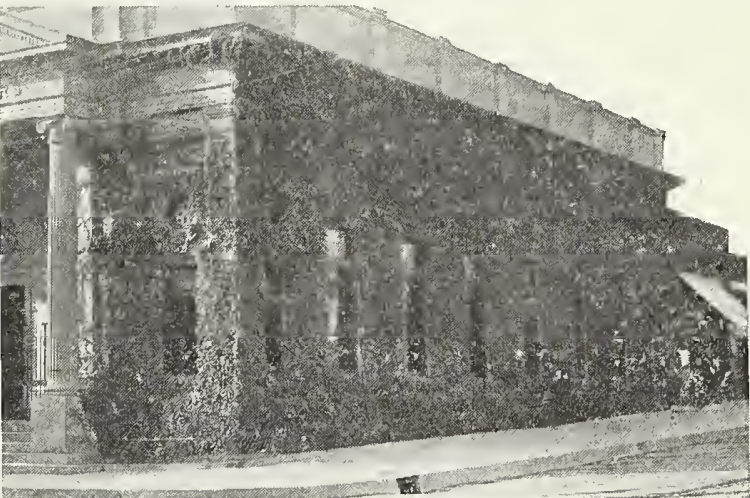

-Ampelopsis (A. Veitchii)

Honeysuckle, Monthly Fragrant, or DutchBlooms all summer; very sweet, red and yellow flowers.

Hall's Japan-Nearly Evergreen; flowers pure white, changing color to yellow, producing abundantly; fragrant like a Jassamine; the best bloomer of all.

Yellow Trumpet-A well known variety, with yellow and trumpet flowers.

Wistaria, Purple-A most beautiful climber of rapid growth, and producing long, pendulous clusters of pale blue flowers; when well established makes an enormous growth, is very hardy, and is one of the most super' vines ever introduced.

Wistaria, White - General characteristics the same as the purple, but the flowers are pure white.

\section{Deciduous Hedge}

Honey Locust - A rapid growing native tree with strong spines and delicate foliage; very hardy and desirable for the North.

Osage Orange-A native tree of medium size and spreading habits; leaves a bright shining green; highly esteen $\rightarrow d$ in the West and South; not hardy enough for Northern states.

Ornamental Hedges - The following shrubs are adapted to this purpose: Althea, California Privet, Japan Quince, Spirea, 'Tartarian Honeysuckle.

Beautify your surroundings now by planting shrubs, vines and hedges. Let some of the long planned pleasures begin with the new season. 


\section{ROSES}

Of all the ornamental shrubs for the garden the Rose easily stands first. The great variety of form, color and size of the plants and flowers gives tliem a widel range of usefulness for decoration than any other plant.

'To secure the best results, plant in rich garden soil, and cultivate well, and when you have done all this implies, then go over the ground again carefully. There is no plant that will respond more fully to kind treatment than the Rose. It is a strong feeder, and when neglected or poorly cared for, will suffer very quickly.

All Roses do belter if properly pruned. They should be more or less pruned when planted by taking off any injured roots or branches and at least one-half of the past season's growth. The plants are best pruned in March. Usually from about one-half to two-thirds of the past year's growth should be cut back. Also all dead branches and such shoots as may crowd the plant or exclude light and air. As a rule the more vigorous growing kinds require less pruning than the weak growing ones. Besides spring pruning many kinds of the Hybrid Perpetual require to be pruned as soon as their first blossoming is over, in order to induce free blooming in the fall.

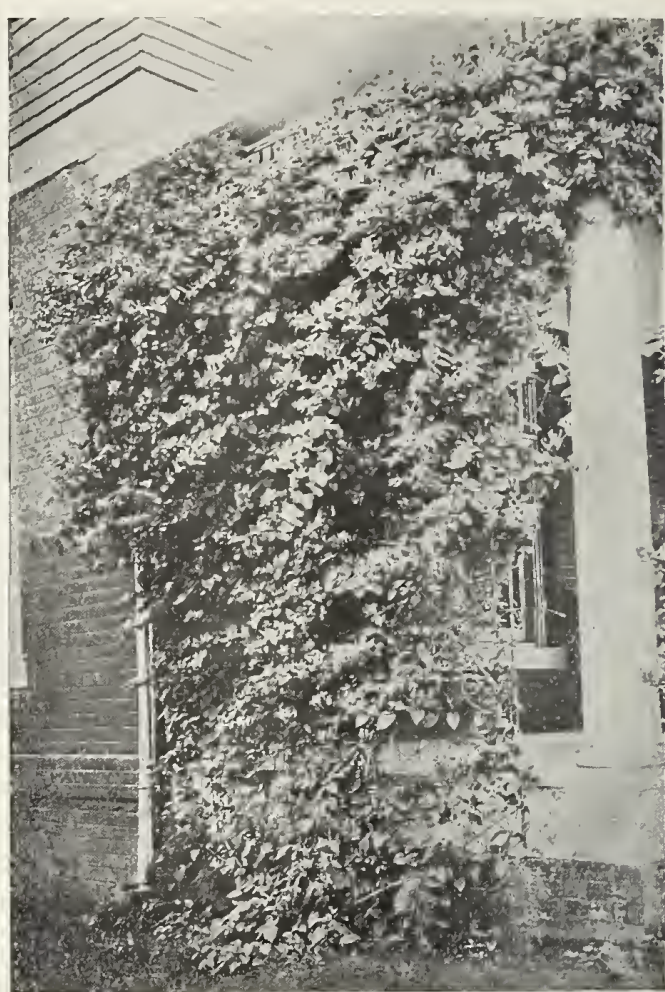

-Hall's Japan Honeysuckle. See Page 33).

All Roses will keep better through the winter if late in the fall they are laid down and lightly covered with earth or wrapped so as to save them from especially severe weather.

It is very important to keep your plants healthy and vigorous and free from diseases and

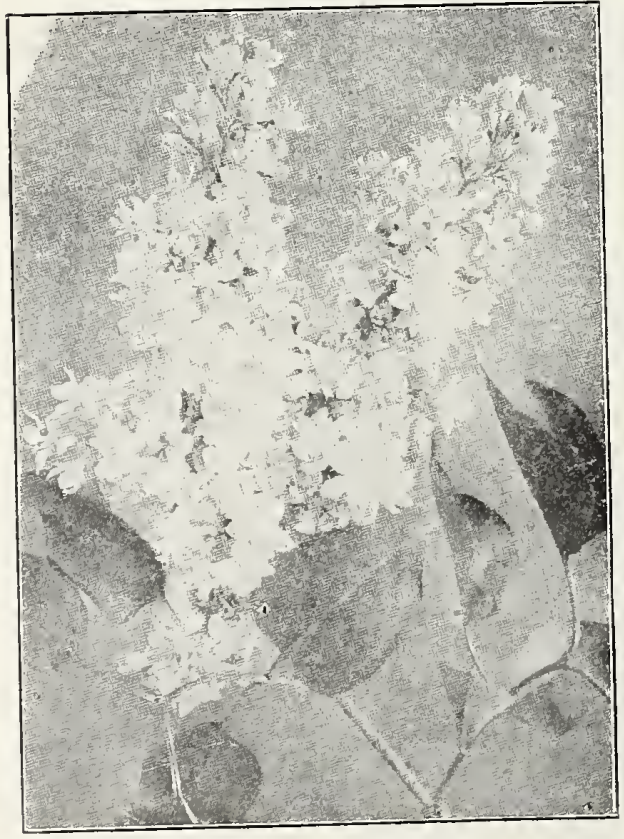

-White Lilac. (See Page 33). insects. Mildew is one of the most injurious of the rose diseases and is generally caused by extremes of heat and cold and by long continued damp and cloudy weather. The Bordeaux mixture is one of the best preventives from mildew. By careful attention the diseases and insects can be kept down and the plants will reward you with heautiful blooms and foliage.

\section{Hybrid Perpetual Roses}

This group comprises, for tbe most part, the loses for the multitude. They are mostly hardy, vigorous, easy of culture. As a general rule they thrive best in well-prepared loam. The flowers range from purest white to deepest crimson, with intermediate shades of pink, blush, cherry, carmine and peach. The term "perpetual" may lead some to think that they are constant bloomers as the everblooming roses. This is not the case. They flower freely in the spring, some of them flower at intervals during the summer and most of them produce a good second crop in the fall.

Alfred Colomb-Brilliant carmine crimson; very large, full and fine, globular form; very fragrant and a splendid rose. 
American Beauty-An ever-blooming $\mathrm{Hy}$ brid Perpetual. The flowers are very large, of beautiful form and very double; color, a deep rich rose. The fragrance is delightful.

Anne de Diesbach-Carmine, beautirul shade; moderately full and very large.

Black Prince-Dark, velvety crimson, almost black; a good grower and a most magnificent rose.

Baron de Bonstetten-Ficl, velvety naroon; large, full; a splendid sort.

Coquette des Blanches-Pure white, flowering in clusters; a very free bloomer.

Coquette des Alps - Thite, lightly shaded with carmine; oî medium size; a free bloomer.

Dinsmore - A true perpetual, flowering very freely the whole season; flowers large and very double; color deep crimscn. The plant is of o, dwarf, bushy habit, every shoot producing a bui.

Earl Dufferin-A strong, healthy growing sort; and a splendid autumn bloomer; flower's are large, very full and finely formed; color deep, velvety crimson, shaded with maroon.

Fisher Holmes-Deep glowing crimson; large, moderately full and of fine form.

Frau Karl Druschki-Very large, perfect form and snow white; long, pointed buds; a vigorous grower and free bloomer.

General Jacqueminot-Brilliant crimson scarlet; very showy and effective; good grower, free bloomer; one of the most popular roses. Especially valued for its large and elegant buds.

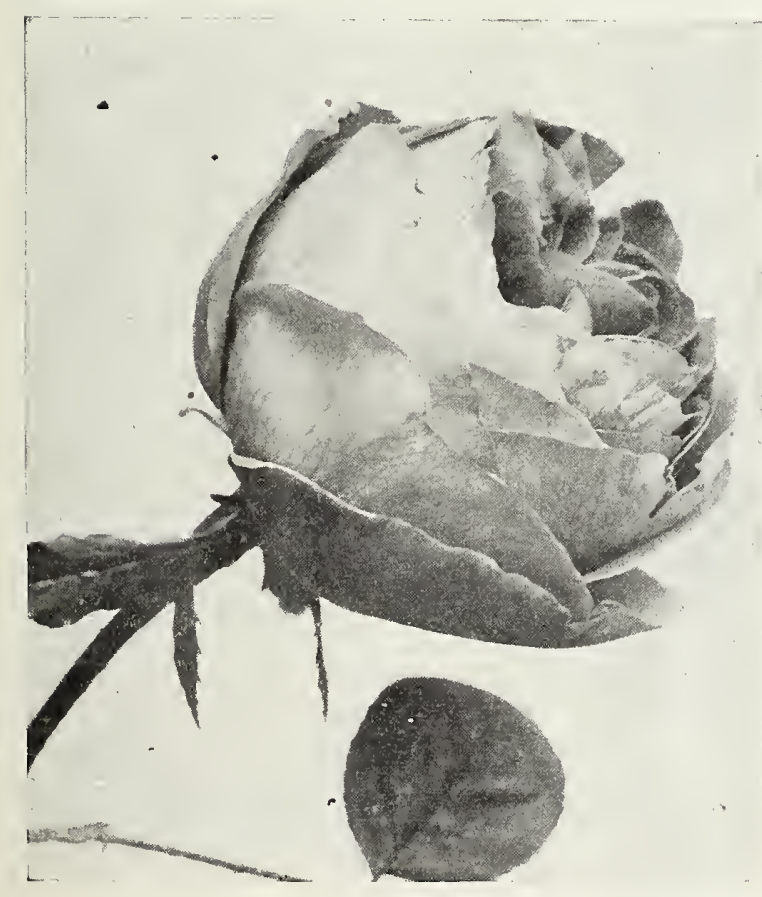

General Washington-Brilliant rosy carmine, large and double; a poor grower and fair bloomer.

John Hopper-Deep rose, with crimson. One of the best.

Madame Chas. Wood-One of the most beautiful Hybrid Perpetual Roses ever introduced. The flower is extra large, full and double; color deep rosy crimson, sometimes brilliant scarlet, with maroon shading.

Magna Charta-Very large and full, bright, clear pink, a good bloomer and very hardy.

Marshall P. Wilder-A vigorous grower, with healthy foliage, flowers large, double and of good form, color a deep red; a good bloomer.

Margaret Dickson-White with pale flesh center petals; very large flowers of magnificent form, both in bud and when fully open; plant perfectly hardy. A vigorous grower; very fragrant.

Mrs. J. H. Laing-One of the finest roses of its class. It is very free flowering, commencing to bloom early and continues to bloom until autumn; color a soft, delicate pink, with a satin tinge; very fragrant.

Paul Neyron-Deep rose; very large, very full; somewhat fragrant, free blooming; the largest variety known.

Pierre Notting-Large, very full, globular, dark red or crimson, shaded violet; fragrant, vigorous. One of the very best dark roses.

Prince Camille de Rohan-Very dark, rich, velvety crimson, passing to intense maroon-shaded black; large, full flowers, looking, at a distance, as if nearly black. One of the darkest roses; very handsome.

UIrich Bruner-Raised from Paul Neyron; brilliant, cherry-red flowers of fine form and finish, petals of great substance; plant vigorous and hardy; one of the best varieties for forcing and open air culture. 
Victor Verdier-Clear rose; globular, of fine form, and a free bloomer; superb.

Vick's Caprice-Beautiful pink flowers of fine size, striped and dashed with white and carmine, especially pretty in bud form. Vigorous and free blooming rose.

\section{MOSS ROSES}

Blanche Moreau-Pure white, large, full and perfect form.

Crested Moss-Deep pink buds, sulrounded with a mossy fringe and crest; fragrant; one of the best.

Countess of Murinais-White, slightly tinged with flesh. One of the best white moss roses.

Glory of Mosses-Pale rose, very large, full and beautiful.

Red Moss-Fine, red flowers and elegant mossy buds.

Salet-Clear, rose color, very double; of vigorous growth and abundant bloom.

\section{CLIMBING ROSES}

Baltimore Belle-A rapid growing dark-leafed rose; blooms in large clusters; flowers pale blush, almost white; double, fragrant.

Empress of China-Light red, changing to pink when fully expanded; a free and continuous bloomer; flowers medium size.

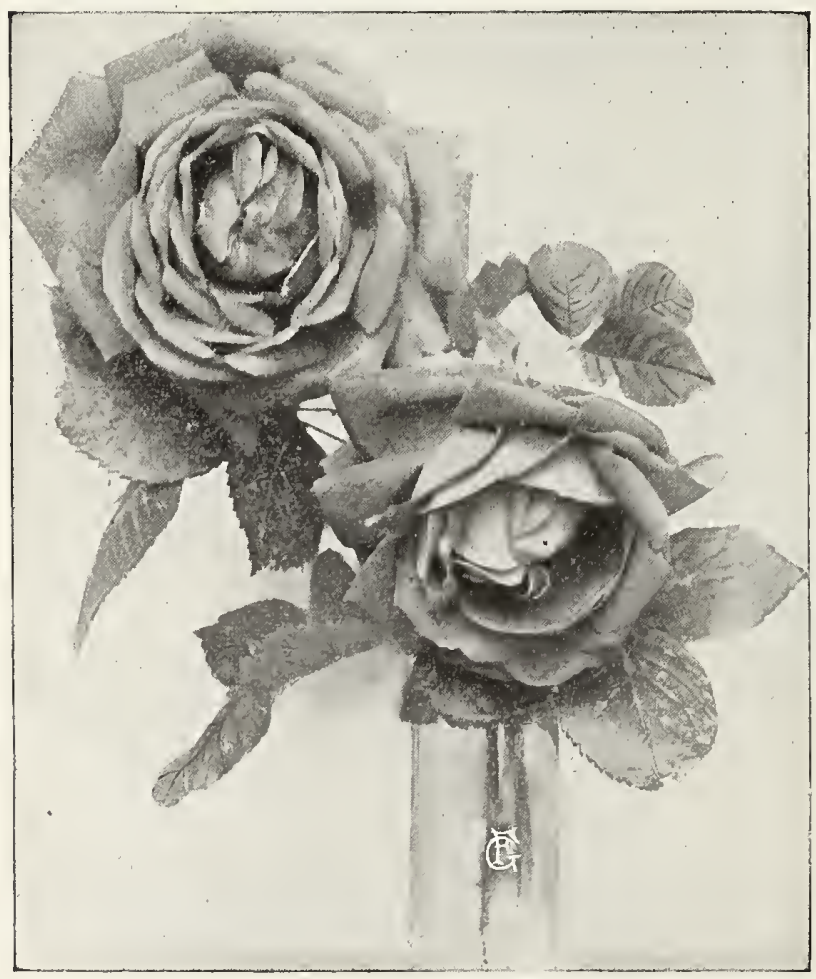

-General Jácrueminot Rose.

Dorothy Perkins-Has the same strong habit of growth as the Crimson Rambler. The flowers are borne in large clusters and are a beautiful shell pink, of medium size and very double. A valuable new climbing rose.

Philadelphia-Flowers are borne in large clusters and are a deep rich crimson, very similar to the Crimson Rambler, but larger and more double. The vine is a strong, quick grower, perfectly hardy and less subject to mildew than the Crimson Rambler.

Pink Rambler-In foliage and habit of growth much like the white Rambler, except the flowers are a bright pink, instead of white.

White Rambler-In habit of growth, foliage, manner of blooming and shape flower is identical with 
Crimson Rambler differing only in color, which is pure clear white.

Yellow Rambler-A hardy, yellow climbing rose, blooming after the same manner as the Crimson Rambler, in large clusters; flowers of medium size, very sweet scented. Color a clear, decided yellow; has successfully withstood, unprotected, a continued temperature of from zero to 2 degrees below, proving it to be the hardiest of ail yellow climbing roses. A rampant grower, strong plant; in full bloom makes one of the finest pillar or porch plants imaginable.

\section{MISCELLANEOUS ROSES}

Baby Rambler-A Dwarf Crimson Rambler. The greatest blooming rose in the world. It blooms in the field all summer. It blooms in the house all winter. It blooms all the time. It is perfectly hardy everywhere.

Clothilde Soupert-Flowers medium size, very double, produced in clusters, pearly white with rosy centers, liable to vary. Valuable for florists or as a pot plant, being remarkably free and constant bloomer and of easy culture. Blooms all summer.

Harrison's Yellow-Bush grows from three to

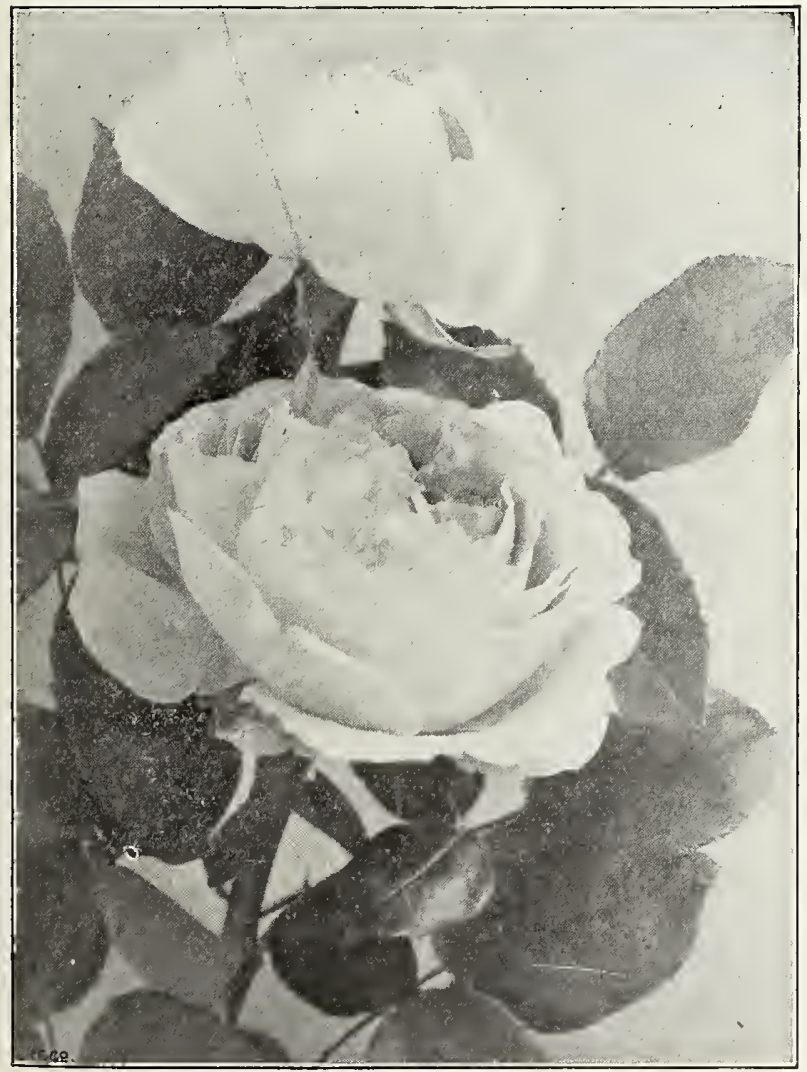

-Paul Neyron Rose.

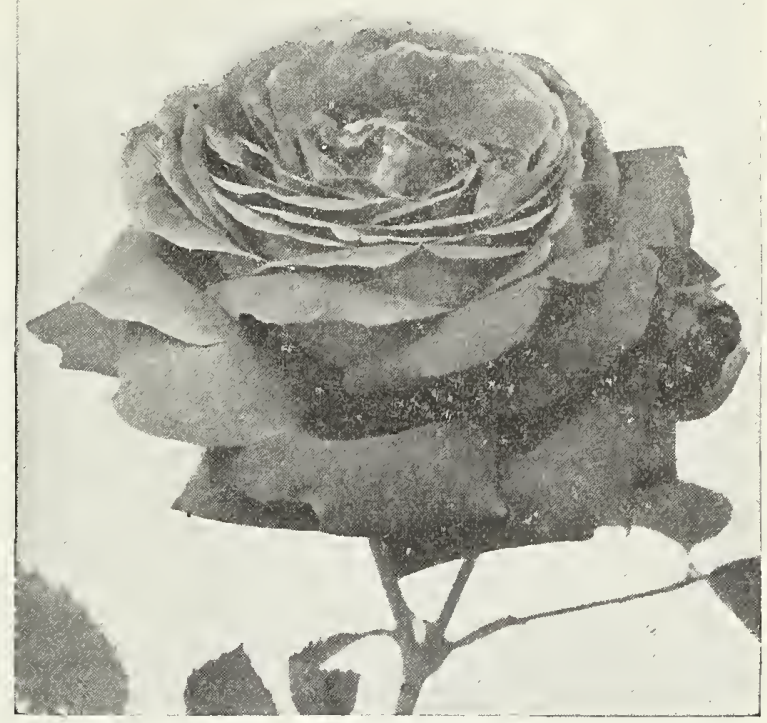

- Marshall P. Wilder Rose.

four feet high, and is a very prolific bloomer. Flowers a deep golden yellow; one of the first roses to bloom in the spring.

Hermosa-An excellent rose, blooms in fine clusters, double and fragrant; color beautiful clear rose, hardy, one of the best. Blooms continually through the summer.

La France-Beautiful silvery pink, more highly flushed at the center; equal in delicacy to the Tea Roses, and greatly surpasses them in hardiness. Very large and full, highly perfumed; bloo m s continually through the summer.

Madam Plantier-A strong, vigorous grower and a profuse bloomer; one of the finest pure white roses, blooming in clusters. Blooms in the spring.

Mary Washington-A wonderfully profuse bloomer; flowers medium size, white or light pink; continues in profuse bloom the entire season.

\section{TREE ROSE}

These are budded or grafted on stems usually about four or five feet high and they form fine dwarf trees. When properly cared for they are a very desirable ornament to the lawn. They are not hardy in severe winters and should be removed to the cellar during the winter.

Our collection of Roses has been gathered together especially to give the greatest satisfaction to our customers. You love roses-of course, you do. Then no longer be without some of the fine plants we offer. 


\section{Plants and Bulbs}

\section{PAEONIES}

'These are all showy bearitiful flowers, perfectly hardy, easy to cultivate, The color's range from the darkest red to pure white, and the flowel's come very early in the spring. No garden is complete without paeonies, and no plant is more popular just now. If paeonies are planted for cut flowers, only a few of the best varieties should be used, as they require cutting at just the right time to secure the best results, and it is difficult to give proper attention to a long list of varieties.

Bryant's White - Large, pure white flowers, plant vigorous and a good bloomer

Festiva Maxima-- Flower white, large, very full and sometimes tipped with carmine. Plant vigorous.

Francis Ortegal-Brilliant crimson; large fine flowers, with yellow stamens.

Giganthea-Large flowers, borne on a long stiff stem; clear light pink; very fragrant.

Queen Victoria-The broad petals are blush white; flowers large and very double

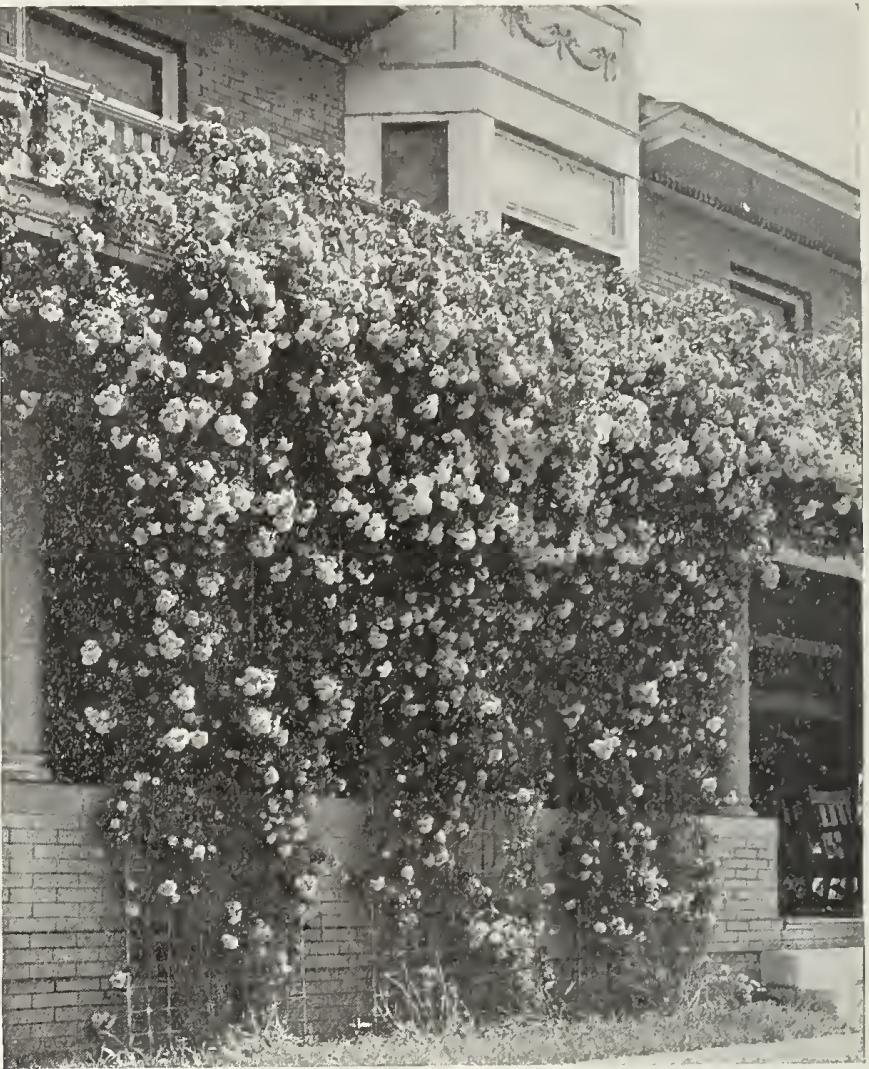

-Dorothy Perkins Climbing Rose.

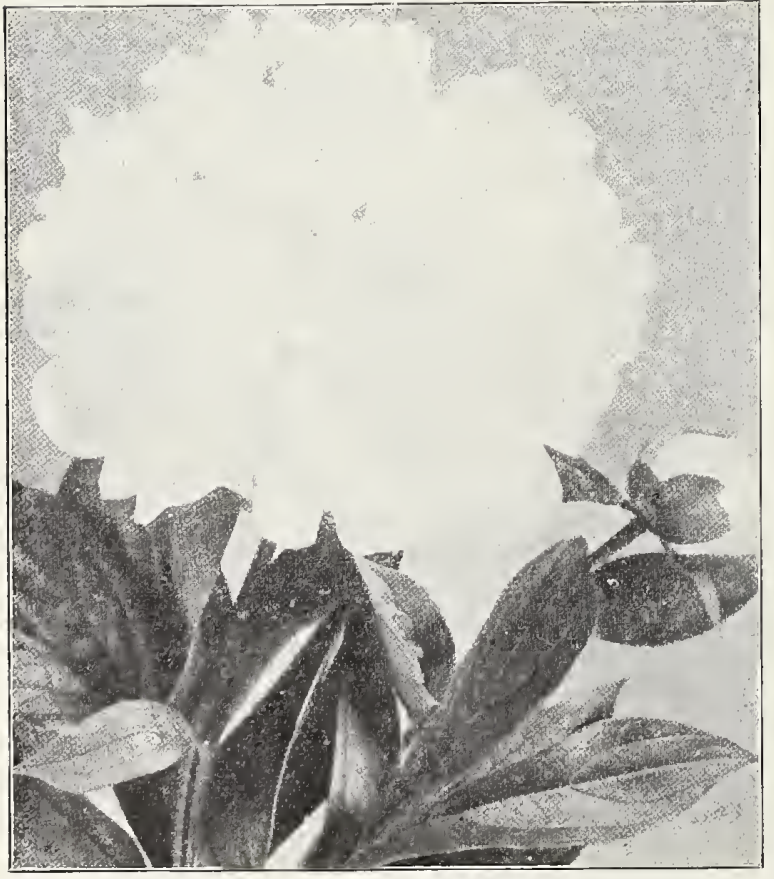

-Festiva Maxima Peony.
Rubra Superba-A rich dark red; large, full and borne on long stems.

\section{IRIS}

German-These plants have broad swordlike leaves and bloom profusely early in the spring. The flowers are showy and extend over a wide range of colors and shades and are fine for cut flowers.

Japan-This is the finest group of the Iris family. The plants are hardy and flower in great profusion in June, The flowers are very large and colorings are delicate and beautiful. They should be planted in a damp, cool place and in rich soil.

\section{PHLOX}

One of the finest late summer and autumn flowers. The plants are of vigorous habit, easy culture and produce in great profusion during a long season. The flowers are of fine form, good substance and of bright and varied colors. They succeed in any good garden soil. They usually flower in July and August and if flowers are wanted later in the season it is necessary to pinch the shoots about the first of June and again in July.

Bridesmaid-White, with a crimson eye Coquelicot-Pure scarlet, with a crimson eye. 
Elizabeth Campbell-Bright salmon pink, with lighter shadings.

Jeanne d'Arc-Large white, one of the reliable standard sorts.

Miss Lingard-Pure white, large and fine. Mrs. Jenkins-Best tall, early white.

Rosenberg-Bright reddish violet, with a blood-red eye. Large flowers, borne in large trusses.

Von Hochberg-Rich crimson and very fine.

\section{Miscellaneous Plants and Bulbs}

Bleeding Heart-A hardy perennial, with fern-like foliage, flowers are heart shaped, rose colored and produced in long drooping spikes. A good border plant. Perfectly hardy and easy to cultivate.

Golden Glow-A tall growing hardy perennial, with light green deeply cut foliage; flowers $3 \frac{1}{2}$ inches in diameter; very double, well formeã; ricin golden yellow and borne on long stems, which render them suitable for cutting. Flowers freely from July until September.

Yucca-A plant of grand appearance. The stem is three feet above the ground, covered with large, bell-shaped flowers on laterals, forming a perfect pyramid, color creamy white.

Cannas-Tall, stately plants, with large leaves varying in color from light green to dark brown or red. The flowers are produced in long spikes and cover a wide range of colors and continue to bloom until frost. After the tops are killed down by frost, the roots should be taken up and stored in a cool, dry place, where they will be protected from the frost.

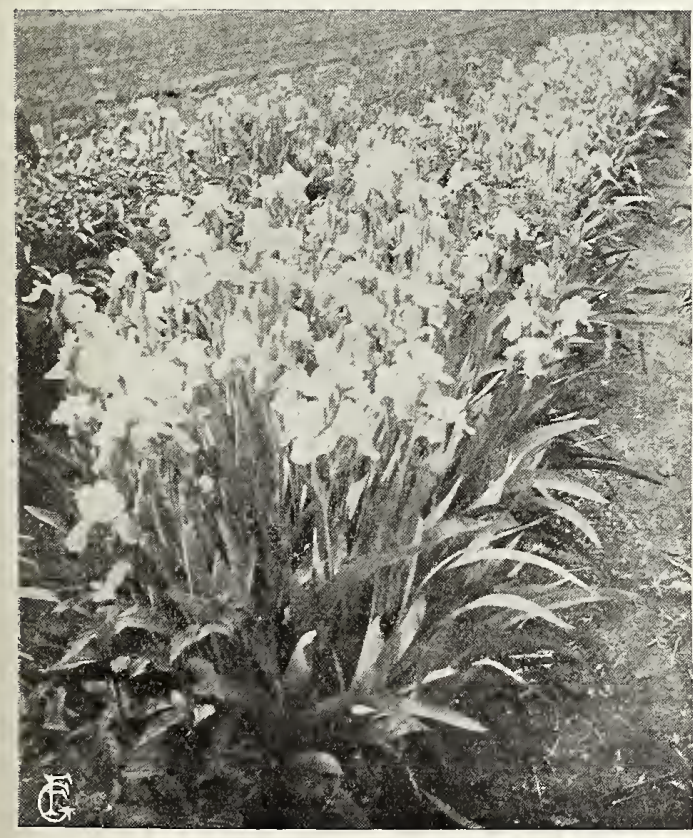

-Iris Germanica.

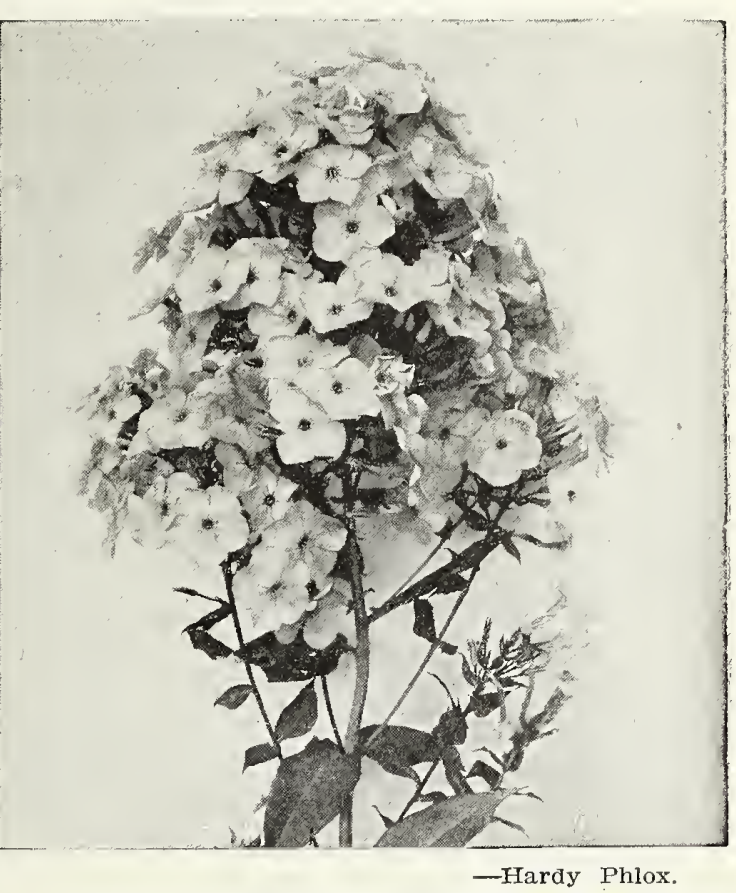

Dahlias-The Dahlia is rapidly coming to the front as one or the most desirable late summer and fall flowering plants. 'The flowers are perfect, showy and produced in great profusion from July until frost. They also cover a wide range of color and form and are useful for cut flowers. The roots should be dug before freezing weather and stored in a frostproof cellar.

Gladiolus-A most attractive summer flowering bulb which deserves a place in every garden. It requires little care and produces long spikes of beautiful flowers of many beautiful shades and colors. If the spikes are picked when two or three of the lower flowers are open and placed in water, the entire spike will open beautifully. The bulbs should be taken up before freezing weather and stored in a trost-proof cellar.

Mexican Tuberose - One of the most highly perfumed and sweetest of summer flowering bulbs. Easily grown in any good garden soil. The flowers are borne in long spikes and are a creamy white. Before the ground freezes in the fall, they should be lifted and stored in a frost-proof cellar.

We have listed the most dependable and desirable fruits and ornamentals suited to the sections reached by us. If you do not find exactly what you want listed here, write us. We may be able to give you valuable assistance in making selections. 


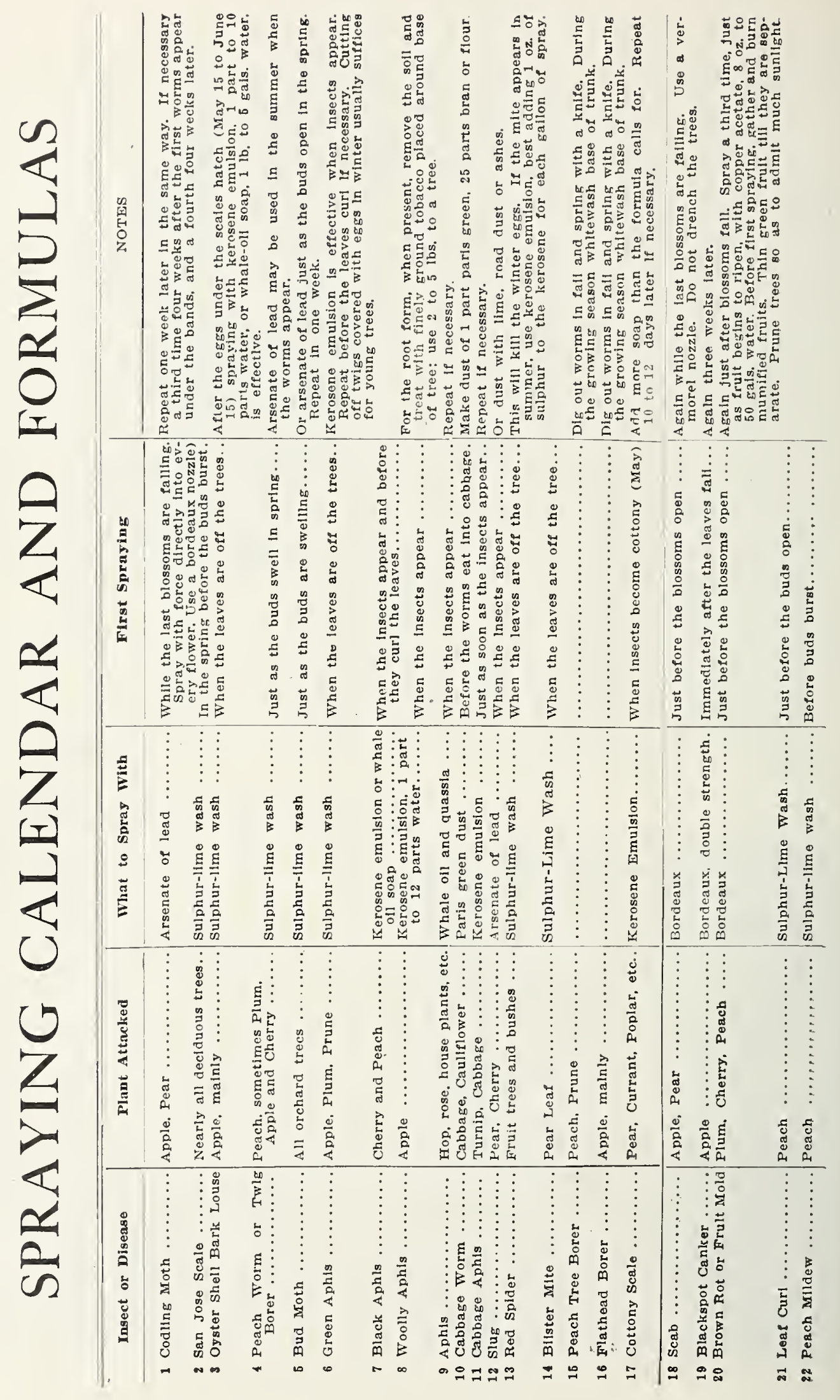



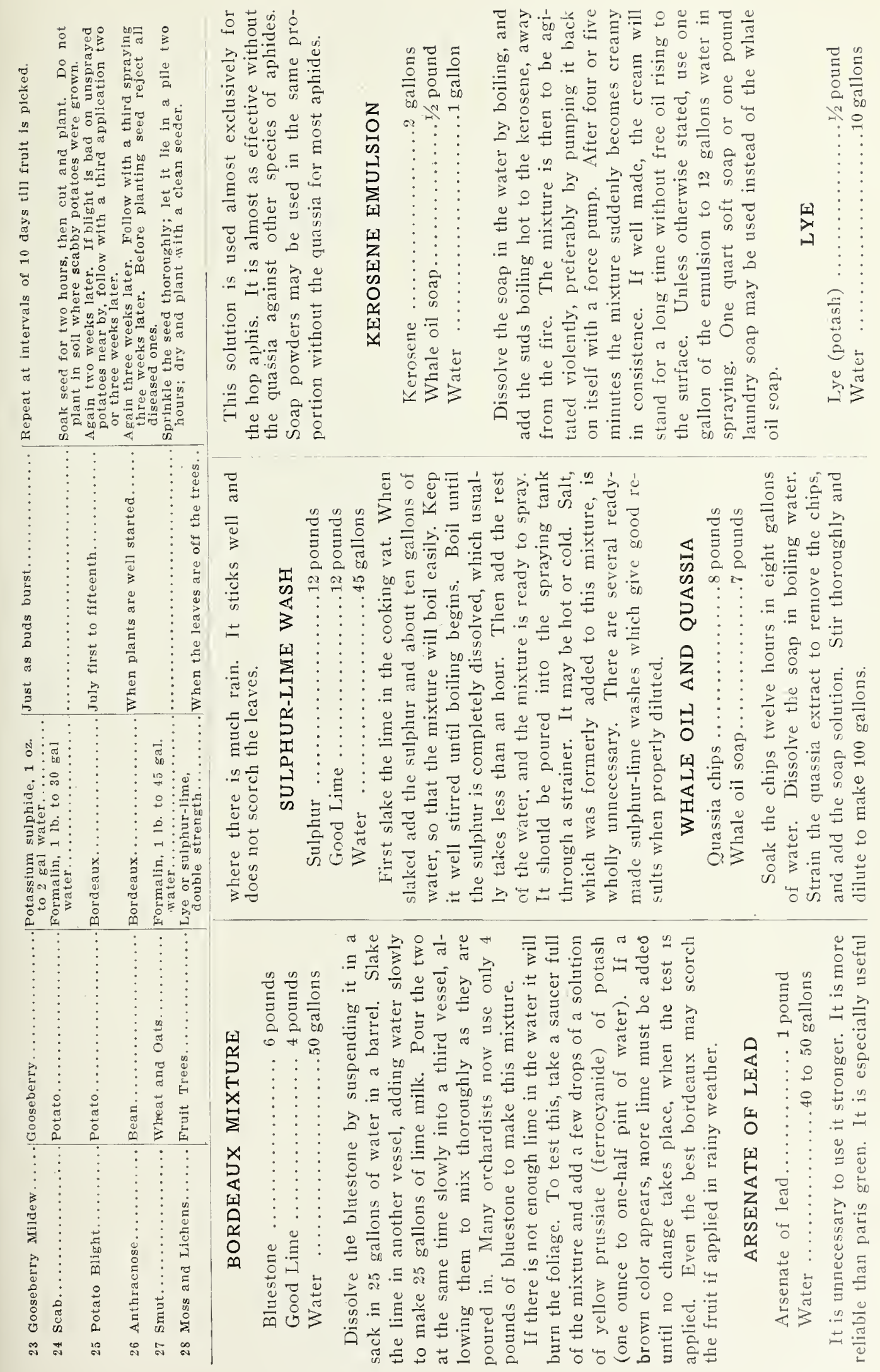


\section{General Index}

Page

Advice to Correspondents............ 4

Almond .......................

Althea $. \ldots \ldots \ldots \ldots \ldots \ldots \ldots \ldots \ldots . \ldots . \ldots . \ldots 3$

Ampelopsis ..................... 34

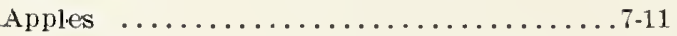

Crabs ...................... 11

Fall ...................... 8

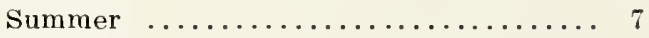

Winter .................... 8

Apricots ......................... 19

Arborvitae, American ............... 32

Pylamidalis $\ldots \ldots \ldots \ldots \ldots \ldots \ldots \ldots \ldots \ldots$

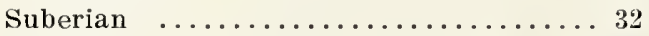

Ash, White ................... 29

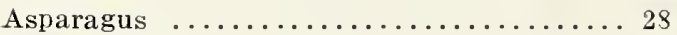

Bignonia ..................... 34

Bilch, Cut-Leaved Weeping .......... 31

European White ................ 29

Blackberries ................. . 25-26

Bleeding Heart ............... 4l

Box Elder .................... 29

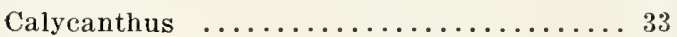

Cannas ....................... 41

Catalpa Bungeii ................. 29

Speciosa ..................... 29

Cherries ...................... 14

Chestnut, American Sweet .......... 21

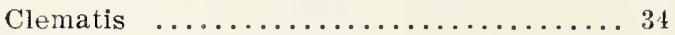

Crab Apples ......................

Bechtel's Double Flowering .......... 29

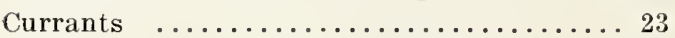

Dahlias ..................... 41

Deciduous Trees, Upright ...........29-31

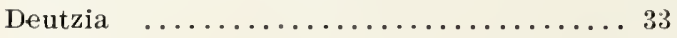

Dewberries ................... 26

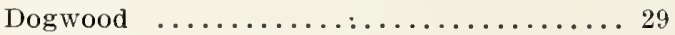

Dutchman's Pipe ................ 34

Elm, American White ............. 30

Camperdown $\ldots \ldots \ldots \ldots \ldots \ldots \ldots \ldots . \ldots 31$

Evergreens .................... 32

Forsythia ....................

Fumigation $\ldots \ldots \ldots \ldots \ldots \ldots \ldots \ldots \ldots \ldots$

Gladiolus ................... 11

Golden Glow .................. 40

Gooseberries .................... 23
Grapes ......................21-22

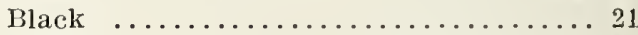

Red .....................21

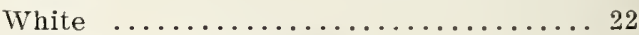

Guarantee of Genuineness .......... 3

Hedge Plants .................. 35

Hardy Vines .................. 34

Honeysuckle, Climbing ........................

Tartarian or Upright ............. 33

Horse Chestnut ................... 30

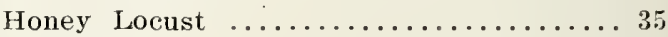

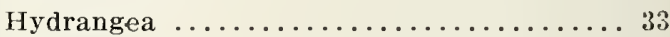

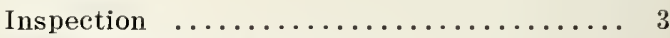

Instructions for Planting ........... 4

Introduction $\ldots \ldots \ldots \ldots \ldots \ldots \ldots \ldots \ldots$

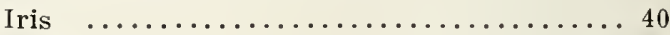

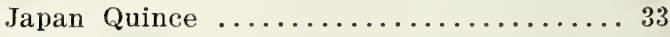

Juneberries ................. 26

Juniper, Irish $\ldots \ldots \ldots \ldots \ldots \ldots \ldots \ldots \ldots$

Lilacs $\ldots \ldots \ldots \ldots \ldots \ldots \ldots \ldots \ldots \ldots . \ldots \ldots$

Linden, American ................ 30

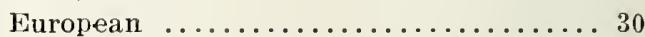

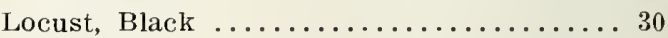

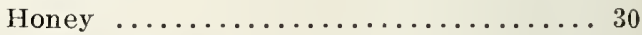

Maple, Ash Leaved ............... 30

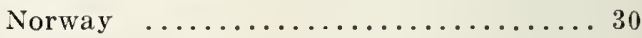

Silver-Leaved $\ldots \ldots \ldots \ldots \ldots \ldots \ldots \ldots \ldots$

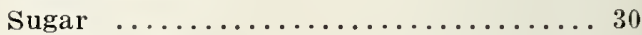

Weir's Cut-Leaved .............. 30

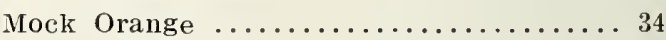

Mt. Ash, European ............... 30

Oak-Leaved .................. 30

Weeping ..................... 32

Mulberries, Downing ............ 20

Hicks $\ldots \ldots \ldots \ldots \ldots \ldots \ldots \ldots . \ldots . \ldots 20$

New American ................ 20

Russian ...................20

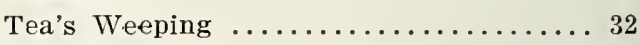

Nectarines $\ldots \ldots \ldots \ldots \ldots \ldots \ldots . \ldots \ldots$

Olive, Russian ................. 31

Ornamental Shrubs .............. 33

Ornamental Hedges .............. 35

Ornamental Department ............ 29

Osage Orange ................... 35

Order Blanks ................ 47-48 


\begin{tabular}{|c|c|}
\hline age & age \\
\hline$\ldots \ldots \ldots \ldots \ldots \ldots$ & oses, Climbing \\
\hline eaches $\ldots \ldots \ldots \ldots \ldots \ldots \ldots \ldots \ldots$. $17-18-19$ & Hybrid Perpetual \\
\hline 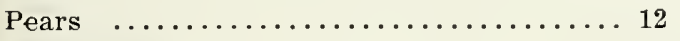 & 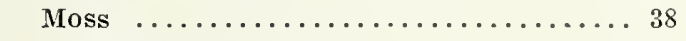 \\
\hline$\ldots \ldots \ldots \ldots \ldots \ldots 31$ & Miscellaneous Roses ............ 39 \\
\hline$\ldots \ldots \ldots \ldots \ldots \ldots \ldots \ldots \ldots \ldots 40$ & 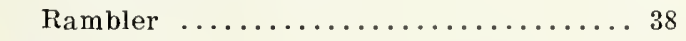 \\
\hline ie Plant ................... 28 & ose Trees . . . . . . . . . . . . . . \\
\hline ine, Austrian . . . . . . . . . . . . . . . 32 & moke Tree. \\
\hline 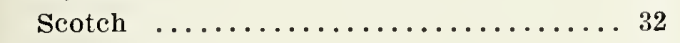 & now Balls ... \\
\hline 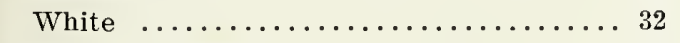 & $\ldots \ldots \ldots \ldots \ldots \ldots \ldots$ \\
\hline s and Bulbs ................. 39 & ing Calendar . ..............42 \\
\hline$\ldots \ldots \ldots \ldots \ldots \ldots \ldots \ldots \ldots \ldots \ldots$ & Norway \\
\hline opean Varieties .............. 15 & $\ldots \ldots \ldots \ldots \ldots \ldots \ldots \ldots 27-28$ \\
\hline ive Varieties ............... 16 & ore $\quad \ldots \ldots \ldots \ldots \ldots \ldots \ldots \ldots \ldots \ldots$ \\
\hline Japan Varieties ...............16-17 & $\ldots \ldots$ \\
\hline lowering $\ldots \ldots \ldots \ldots \ldots \ldots 33$ & les for Planting .... \\
\hline ple-Leaved $\ldots \ldots \ldots \ldots \ldots \ldots$ & $\ldots \ldots \ldots \ldots \ldots \ldots \ldots \ldots$ \\
\hline oplar, Carolina ................. 31 & tment of Trees When Frozen........ \\
\hline Lombardy $\ldots \ldots \ldots \ldots \ldots \ldots \ldots \ldots \ldots \ldots$ & pet Creeper $\ldots \ldots \ldots \ldots \ldots \ldots \ldots$ \\
\hline . . 31 & Tube Roses, Mexican . \\
\hline r-Leaved & $\ldots \ldots \ldots \ldots \ldots \ldots$ \\
\hline rivet, California . .............. 33 & Weeping Deciduous Trees ........... \\
\hline 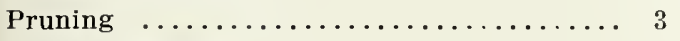 & $\ldots \ldots \ldots \ldots \ldots$ \\
\hline e Fringe & lia \\
\hline 20 & Willow, Kilmarnock \\
\hline erries & consin Weeping . \\
\hline Red Bud ...... & ring Trees ...... \\
\hline ed Cedar & staria \\
\hline Rhubarb ... & ucca \\
\hline
\end{tabular}

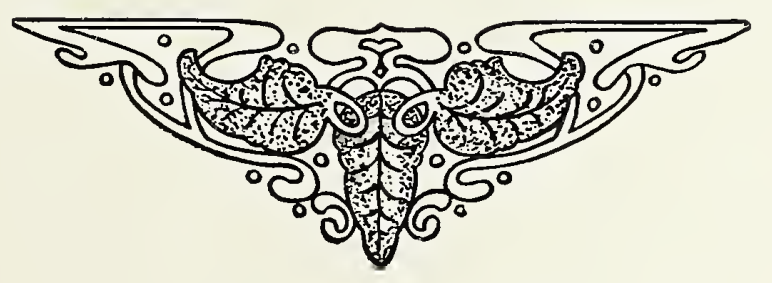


Press of
THE FRUIT-GROWER
St. Joseph, MO. 

